\title{
SUBTASK 2.1 - EFFECTS OF COFIRING LIGNIN AND BIOSOLIDS WITH COAL ON FIRESIDE PERFORMANCE AND COMBUSTION PRODUCTS
}

Final Report

(for the period April 1, 2002, through June 30, 2002)

Prepared for:

AAD Document Control

U.S. Department of Energy

National Energy Technology Laboratory

626 Cochrans Mill Road, MS922-273C

Pittsburgh, PA 15236-0940

Cooperative Agreement No. DE-FC26-98FT41129

Performance Monitor: Sean I. Plasynski

Prepared by:

Kevin C. Galbreath

Energy \& Environmental Research Center

University of North Dakota

PO Box 9018

Grand Forks, ND 58202-9018 


\section{EERC DISCLAIMER}

LEGAL NOTICE This research report was prepared by the Energy \& Environmental Research Center (EERC), an agency of the University of North Dakota, as an account of work sponsored by the U.S. Department of Energy. Because of the research nature of the work performed, neither the EERC nor any of its employees makes any warranty, express or implied, or assumes any legal liability or responsibility for the accuracy, completeness, or usefulness of any information, apparatus, product, or process disclosed, or represents that its use would not infringe privately owned rights. Reference herein to any specific commercial product, process, or service by trade name, trademark, manufacturer, or otherwise does not necessarily constitute or imply its endorsement or recommendation by the EERC.

\section{ACKNOWLEDGMENT}

This report was prepared with the support of the U.S. Department of Energy (DOE) National Energy Technology Laboratory Cooperative Agreement No. DE-FC26-98FT41129. However, any opinions, findings, conclusions, or recommendations expressed herein are those of the author(s) and do not necessarily reflect the views of DOE. 


\title{
SUBTASK 2.1 - EFFECTS OF COFIRING LIGNIN AND BIOSOLIDS WITH COAL ON FIRESIDE PERFORMANCE AND COMBUSTION PRODUCTS
}

\begin{abstract}
Lignin, derived from municipal solid waste and biosolid feedstocks using Masada Resource Group's patented CES OxyNolTM process, and acidified biosolids were evaluated as supplemental fuels with coal for producing steam and electricity. Tests were conducted in a pilot-scale $(550,000-\mathrm{Btu} / \mathrm{hr}[580-\mathrm{MJ} / \mathrm{hr}])$ combustion system to evaluate the effects of coal characteristics, blend mixture (on a dry wt\% basis) and furnace exit gas temperature (FEGT) on boiler heatexchange surface slagging and fouling, $\mathrm{NO}_{\mathrm{x}}$ and $\mathrm{SO}_{\mathrm{x}}$ production, fly ash characteristics, and combustion efficiency. The effects of blending lignin and acidified biosolids with coal on fuel handling and pulverization characteristics were also addressed.
\end{abstract}

An $80 \mathrm{wt} \%$ Colorado-20 wt\% subbituminous Powder River Basin coal blend from the Tennessee Valley Authority Colbert Steam Plant, hereafter referred to as the Colbert coal, and a bituminous Pittsburgh No. 8 coal were tested. The lignin and acidified biosolids were characterized by possessing higher moisture content and lower carbon, hydrogen, and heating values relative to the coals. Ash contents of the fuels were similar. The lignin also possessed higher concentrations of $\mathrm{TiO}_{2}, \mathrm{CaO}$, and $\mathrm{SO}_{3}$ and lower concentrations of $\mathrm{SiO}_{2}, \mathrm{Al}_{2} \mathrm{O}_{3}, \mathrm{Fe}_{2} \mathrm{O}_{3}, \mathrm{~K} 2 \mathrm{O}$, and $\mathrm{N}$ relative to the coals. The sulfur content of lignin could be reduced through a more thorough washing and drying of the lignin in an efficient commercial-scale dewatering device. Acidified biosolids were distinguished by higher concentrations of $\mathrm{P}_{2} \mathrm{O}_{5}$ and $\mathrm{MgO}$ and lower $\mathrm{SiO}_{2}$ and $\mathrm{Al}_{2} \mathrm{O}_{3}$ relative to the other fuels. Trace element concentrations, especially for $\mathrm{Cr}, \mathrm{Pb}, \mathrm{Hg}$, and $\mathrm{Ni}$, were generally greater in the lignin and acidified biosolid fuels relative to the Colbert coal. Maximum trace element emission factors were calculated for 95:5 Colbert coal-lignin and 90:5:5 Colbert coal-lignin-acidified biosolid blends and compared to U.S. Environmental Protection Agency emission factors for pulverized coal-fired units that are unequipped with pollution control devices. Calculated maximum trace element emission factors for the fuel blends were generally less than or within the range of those for the uncontrolled coal-fired units, except for $\mathrm{Cr}$ and $\mathrm{Pb}$ which were greater.

The lignin and biosolids dried to $<40 \mathrm{wt} \%$ moisture did not present handling, pulverization, or fuel homogeneity problems. Nine combustion tests, described in the table below, were conducted. Ash mass balance measurements were used to calculate ash deposition rates (ash deposition rate $=$ deposit, g/total ash input, $\mathrm{kg}$ ) to simulated superheater surfaces in the pilot-scale combustion system. Deposition rates were lowest for the baseline (100:0:0) Colbert coal tests and highest for the 90:10 Colbert coal-lignin blend tested at the higher FEGT of $2350^{\circ} \mathrm{F}\left(1290^{\circ} \mathrm{C}\right)$. The combination of lignin cofiring and relatively high FEGT enhanced the rate of ash deposition by about $410 \%$. Lignin cofiring at the FEGT of $2200^{\circ} \mathrm{F}\left(1200^{\circ} \mathrm{C}\right)$ and blend levels of 5 and 10 dry wt $\%$ increased the ash deposition rate relative to the baseline Colbert coal by $18 \%$ and $79 \%$, respectively. Deposition rates for the acidified biosolid cofire tests (i.e., Colbert coal-lignin-biosolid blends of 90:5:5 and 90:0:10) were $34 \%$ and $128 \%$ greater than those resulting from lignin cofiring alone at the lower FEGT of $2200^{\circ} \mathrm{F}\left(1200^{\circ} \mathrm{C}\right)$. The biosolids promote ash deposition more so than the lignin.

Although combustion test results indicate that the cofiring of lignin and/or acidified biosolids with Colbert coal will increase ash deposition, the deposits produced at a FEGT of $2200^{\circ} \mathrm{F}\left(1200^{\circ} \mathrm{C}\right)$ 
were friable and very loosely bound to simulated superheater surfaces. Therefore, these deposits should be easily removed via sootblowing in a full-scale boiler. The cofiring of relatively low proportions ( $\leq 5 \mathrm{dry} \mathrm{wt} \%$ ) of lignin and/or biosolids at a FEGT of $\leq 2200^{\circ} \mathrm{F}\left(\leq 1200^{\circ} \mathrm{C}\right)$ should not create catastrophic ash deposition problems. However, the combination of relatively high lignin and/or biosolid blend proportions ( $\geq 10$ dry wt $\%)$ and FEGT of $\geq 2350^{\circ} \mathrm{F}\left(\geq 1290^{\circ} \mathrm{C}\right)$ is expected to produce large tenacious deposits and thus should be avoided. Benefits of cofiring relatively small proportions of lignin and/or biosolids with the Colbert coal are primarily threefold: 1) increased utilization of biomass energy, 2) reduced $\mathrm{NO}_{x}$ emissions, and 3) improved combustion efficiency resulting in reduced fly ash carbon contents.

The cofiring of 10 dry wt $\%$ lignin with the Pittsburgh No. 8 coal did not significantly affect entrained ash/bottom ash partitioning or the ash deposition rate, even though thermodynamic calculations predicted the formation of additional low-viscosity silicate liquid. In contrast to the Colbert coal, the cofiring of lignin with Pittsburgh No. 8 coal at a FEGT of $2350^{\circ} \mathrm{F}\left(1290^{\circ} \mathrm{C}\right)$ did not reduce $\mathrm{NO}_{x}$, but it did reduce $\mathrm{SO}_{2}$ via ash sulfation (i.e., formation of anhydrite).

\section{Combustion Test Matrix}

\begin{tabular}{lc}
\hline Coal-Lignin-Biosolid Blend Ratio, dry wt $\%$ & FEGT, ${ }^{\circ} \mathrm{F}\left({ }^{\circ} \mathrm{C}\right)$ \\
\hline $100^{\mathrm{a}}: 0: 0$ & $2200(1200)$ \\
$90^{\mathrm{a}}: 10: 0$ & $2200(1200)$ \\
$95^{\mathrm{a}}: 5: 0$ & $2200(1200)$ \\
$90^{\mathrm{a}}: 5: 5$ & $2200(1200)$ \\
$90^{\mathrm{a}}: 0: 10$ & $2200(1200)$ \\
$100^{\mathrm{b}}: 0: 0$ & $2350(1290)$ \\
$90^{\mathrm{b}}: 10: 0$ & $2350(1290)$ \\
$90^{\mathrm{a}}: 10: 0$ & $2350(1290)$ \\
$100^{\mathrm{a}}: 0: 0$ & $2350(1290)$ \\
\hline $80 \mathrm{w} \% \mathrm{C}$
\end{tabular}

a $80 \mathrm{wt} \%$ Colorado-20 wt \% Powder River Basin coal blend.

${ }^{\mathrm{b}}$ Pittsburgh No. 8 coal. 


\section{TABLE OF CONTENTS}

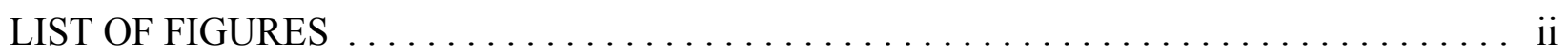

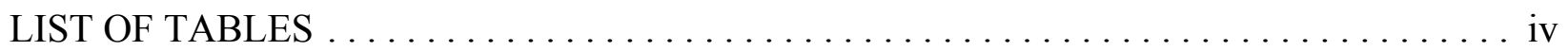

$1.0 \quad$ INTRODUCTION $\ldots \ldots \ldots \ldots \ldots \ldots \ldots \ldots \ldots \ldots \ldots \ldots \ldots \ldots \ldots \ldots \ldots$

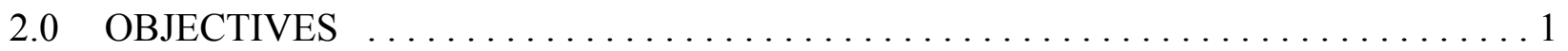

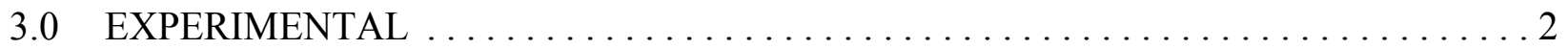

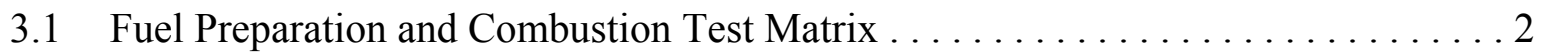

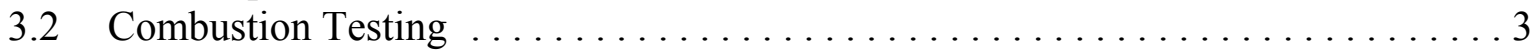

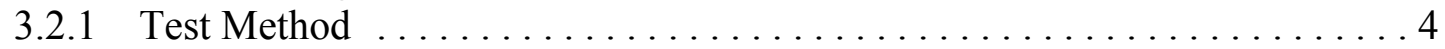

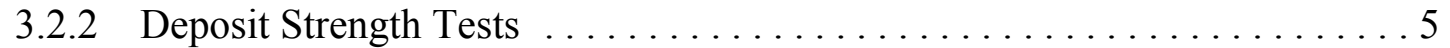

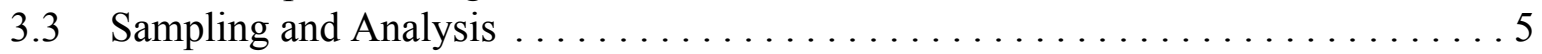

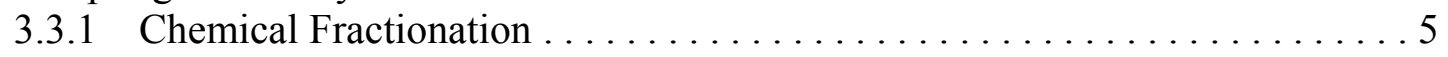

3.3.2 Computer-Controlled Scanning Electron Microscopy . . . . . . . . . . 7

$4.0 \quad$ RESULTS . . . . . . . . . . . . . . . . . . . . . . . . . . . . . . . 7

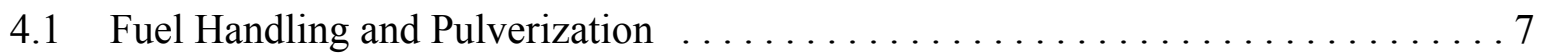

4.2 Fuel Chemical and Mineralogical Compositions $\ldots \ldots \ldots \ldots \ldots \ldots \ldots \ldots$

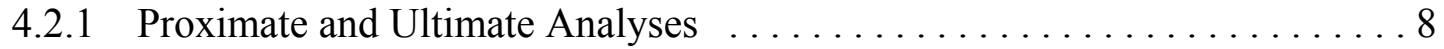

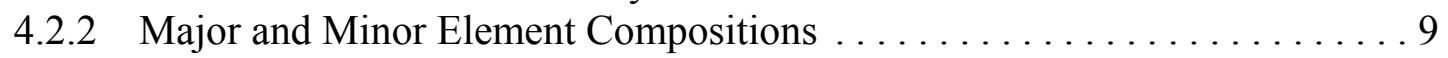

4.2 .3 Chemical Fractionation Analyses . . . . . . . . . . . . . . . 10

4.2.4 Trace Element Analysis Results and Calculated Maximum Emission

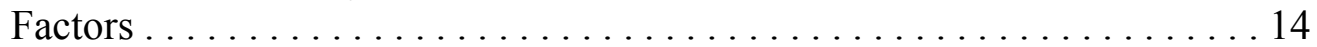

4.2.5 Mineralogy .................................. 16

4.3 Thermal Analysis of Lignin and Acidified Biosolid Fuels . . . . . . . . . . . . . 18

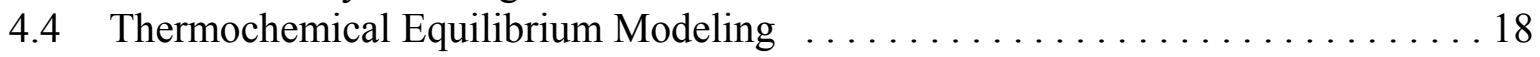

4.4.1 Predicted Partial Melting and Liquid Viscosities ............... 18

4.4.2 Predicted Effects of Lignin and Biosolid Blending on Ash Sulfation . . . . . 21

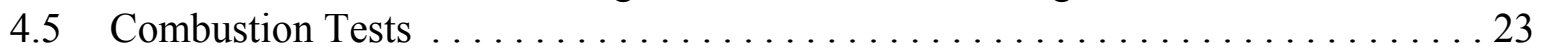

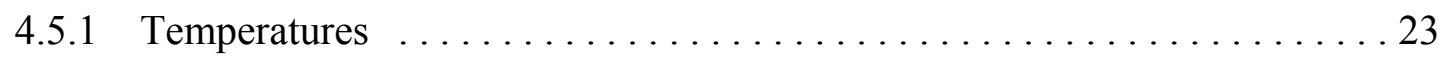

4.5.2 Ash Partitioning and Deposition Rates ..................... 25

4.5.3 Deposit Morphology and Hardness ....................... 29

4.5.4 Deposit Chemical and Mineralogical Compositions .............. 29

4.5.5 Flue Gas Compositions .............................. 35

4.5.6 Fly Ash Particle-Size Distributions $\ldots \ldots \ldots \ldots \ldots \ldots \ldots \ldots \ldots \ldots \ldots \ldots$

4.5.7 Fly Ash Chemical and Mineralogical Compositions ................ 39

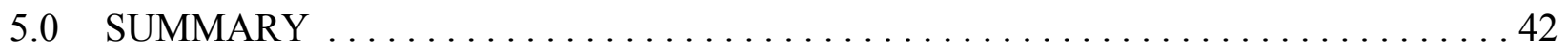

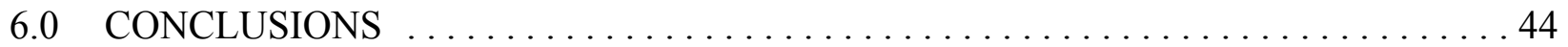

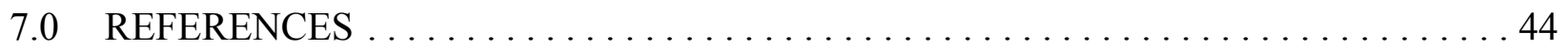




\section{LIST OF FIGURES}

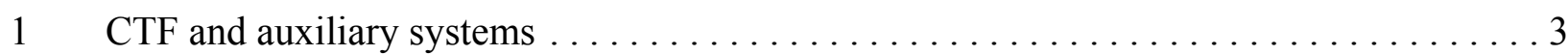

2 Colbert coal blend chemical fractionation results $\ldots \ldots \ldots \ldots \ldots \ldots \ldots \ldots \ldots$

3 Lignin chemical fractionation results $\ldots \ldots \ldots \ldots \ldots \ldots \ldots \ldots \ldots \ldots$

4 Biosolid chemical fractionation results $\ldots \ldots \ldots \ldots \ldots \ldots \ldots \ldots \ldots \ldots \ldots$

5 Comparison of mineral-size distributions for the Colbert coal blend, Pittsburgh No. 8,

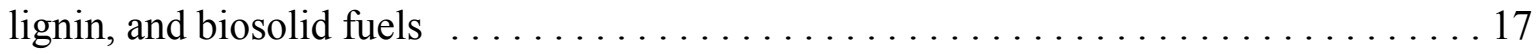

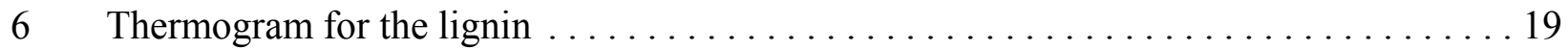

7 Thermogram for the acidified biosolids $\ldots \ldots \ldots \ldots \ldots \ldots \ldots \ldots \ldots \ldots \ldots \ldots \ldots \ldots \ldots \ldots$

8 Predicted partial melting characteristics of parent fuel ashes $\ldots \ldots \ldots \ldots \ldots$

9 Predicted partial melting characteristics of Colbert parent coal and fuel blend ashes . . . 20

10 Predicted partial melting characteristics of Pittsburgh No. 8 and Pittsburgh

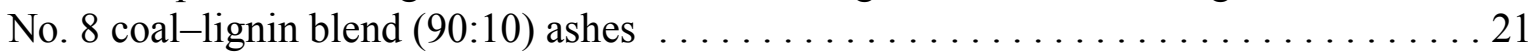

11 Comparison of predicted slag viscosities for parent fuels $\ldots \ldots \ldots \ldots \ldots \ldots \ldots 22$

12 Comparison of predicted slag viscosities for Colbert coal and Colbert

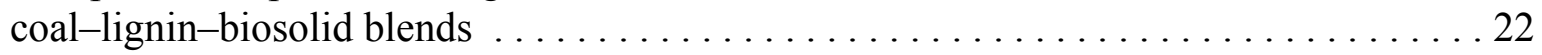

13 Comparison of predicted slag viscosities for Pittsburgh No. 8 coal and a

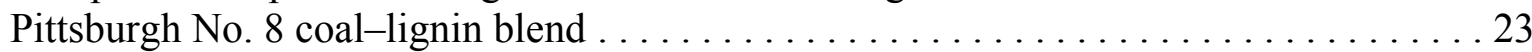

14 Predicted ash sulfate compound concentration as a function of temperature for the Colbert coal and Colbert coal-lignin-biosolid blends $\ldots \ldots \ldots \ldots \ldots \ldots 24$

15 Predicted ash sulfate compound concentration as a function of temperature for the Pittsburgh No. 8 coal, lignin, and Pittsburth No. 8 coal-lignin (90:10) blend . . . 24

16 Bottom ash/entrained ash partitioning for Colbert coal-lignin-biosolid

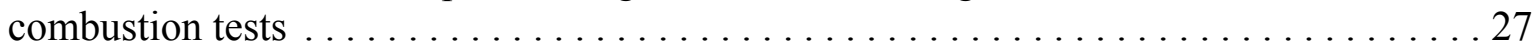

17 Bottom ash/entrained ash partitioning for Pittsburgh No. 8 coal-lignin combustion tests . . . . . . . . . . . . . . . . . . . . . . . . . . 27

continued ... 


\section{LIST OF FIGURES (continued)}

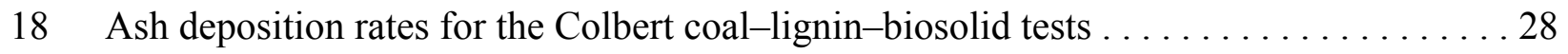

19 Ash deposition rates for the Pittsburgh No. 8 coal-lignin tests . . . . . . . . . . . . . 29

20 Photograph of the deposit produced by burning Colbert coal at a

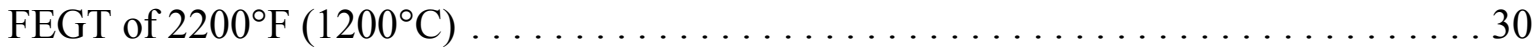

21 Photograph of the deposit produced by burning Colbert coal-lignin (95:5) blend at a

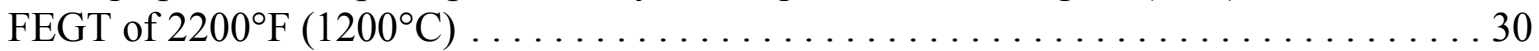

22 Photograph of the deposit produced by burning a Colbert coal-lignin (90:10)

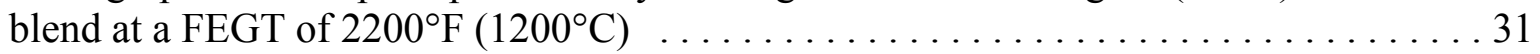

23 Photograph of the deposit produced by burning Colbert coal-lignin (90:10)

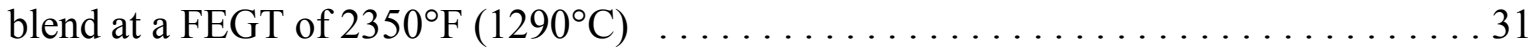

24 Photograph of the deposit produced by burning a Colbert coal-lignin-biosolid

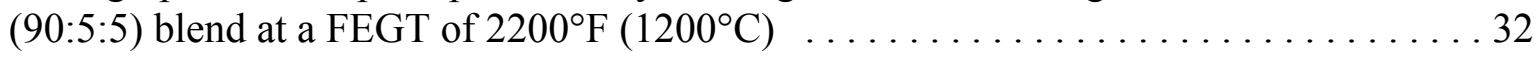

25 Photograph of the deposit produced by burning a Colbert coal-biosolid (90:10)

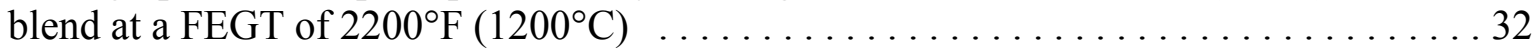

26 Photograph of the deposit produced by burning a Pittsburgh No. 8 coal at a

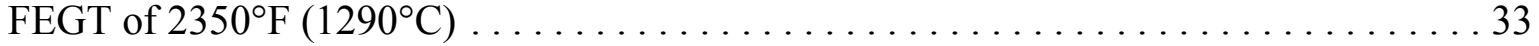

27 Comparison of Colbert coal and Colbert coal-lignin-biosolid fly ash particle-size distributions . ............................... 38

28 Comparison of Pittsburgh No. 8 coal and Pittsburgh No. 8 coal-lignin fly ash

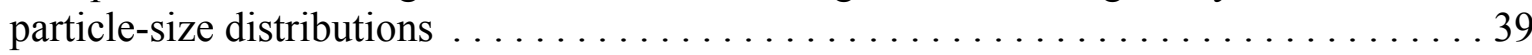




\section{LIST OF TABLES}

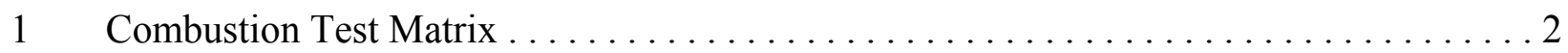

2 Ranking Scheme for Fouling Potential $\ldots \ldots \ldots \ldots \ldots \ldots \ldots \ldots \ldots \ldots \ldots \ldots \ldots \ldots \ldots \ldots \ldots$

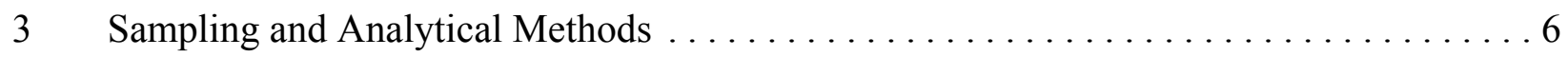

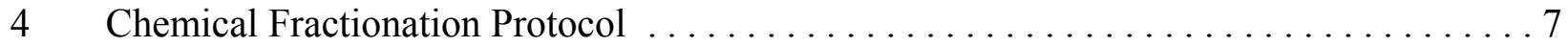

$5 \quad$ Fuel Proximate Analysis Results $\ldots \ldots \ldots \ldots \ldots \ldots \ldots \ldots \ldots \ldots \ldots$

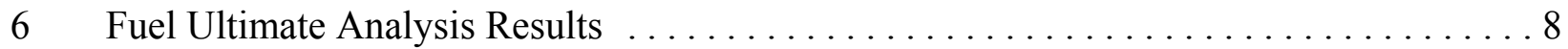

7 Test Fuel Proximate Analysis Results $\ldots \ldots \ldots \ldots \ldots \ldots \ldots \ldots \ldots \ldots$

8 Test Fuel Ultimate Analysis Results $\ldots \ldots \ldots \ldots \ldots \ldots \ldots \ldots \ldots \ldots \ldots$

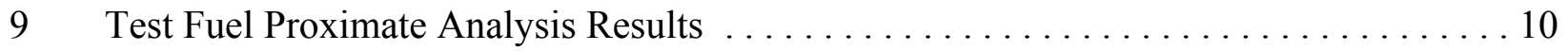

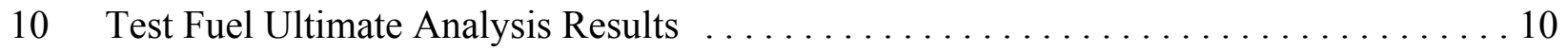

11 Comparison of Parent Fuel Chemical Compositions $\ldots \ldots \ldots \ldots \ldots \ldots \ldots \ldots \ldots$

12 Baseline Colbert Coal and Fuel Blend Chemical Compositions $\ldots \ldots \ldots \ldots \ldots \ldots 11$

13 Baseline Pittsburgh No. 8 Coal and Fuel Blend Chemical Compositions . . . . . . . . . . 12

14 Fuel Trace Element Analysis Results $\ldots \ldots \ldots \ldots \ldots \ldots \ldots \ldots \ldots \ldots \ldots \ldots \ldots$

15 Calculated Maximum Trace Element Emission Factors $\ldots \ldots \ldots \ldots \ldots \ldots \ldots \ldots$

16 Comparison of Trace Element Emission Factors $\ldots \ldots \ldots \ldots \ldots \ldots \ldots \ldots \ldots \ldots \ldots$

17 Mineral Classifications and Nominal Chemical Formulas $\ldots \ldots \ldots \ldots \ldots$

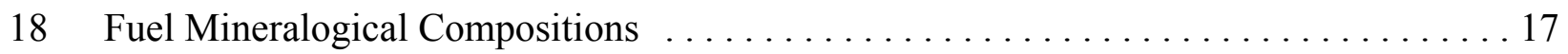

19 Colbert Coal-Lignin-Biosolid Combustion System Temperatures . . . . . . . . . . . . 25

20 Pittsburgh No. 8 Coal-Lignin Combustion System Temperatures . . . . . . . . . . 25

continued ... 


\section{LIST OF TABLES (continued)}

21 Ash Recoveries for Colbert Coal-Lignin-Biosolid Tests $\ldots \ldots \ldots \ldots \ldots \ldots \ldots$

22 Ash Recoveries for Pittsburgh No. 8 Coal-Lignin Blend Tests . . . . . . . . . . . 26

23 Colbert Coal-Lignin-Biosolid Deposit Major and Minor Element Compositions . . . . . 33

24 Probe Surface White Ash Major and Minor Element Compositions

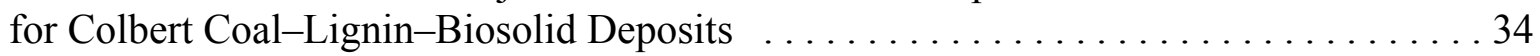

25 Colbert Coal-Lignin-Biosolid Deposit Phase Assemblage . . . . . . . . . . . . . . 35

26 Pittsburgh No. 8 Coal-Lignin Deposit Major and Minor Element Compositions . . . . . . 36

27 Probe Surface White Ash Major and Minor Element Compositions for

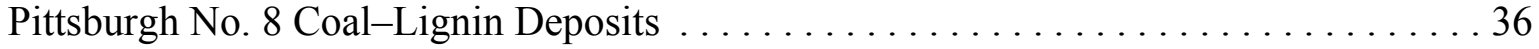

28 Pittsburgh No. 8 Coal-Lignin Deposit Phase Assemblage . . . . . . . . . . . . . . . 37

29 Flue Gas Analysis Results for Colbert Coal-Lignin-Biosolid Tests . . . . . . . . . . . . . 37

30 Flue Gas Analysis Results for Pittsburgh No. 8 Coal-Lignin Tests . . . . . . . . . . 38

31 Colbert Coal-Lignin-Biosolid Fly Ash Major and Minor Element Compositions . . . . . 40

32 Colbert Coal-Lignin-Biosolid Fly Ash Phase Assemblages . . . . . . . . . . . . . . 40

33 Pittsburgh No. 8 Coal-Lignin Fly Ash Major and Minor Element Compositions . . . . . 41

34 Pittsburgh No. 8 Coal-Lignin Fly Ash Phase Assemblage . . . . . . . . . . . . . . 41 


\section{SUBTASK 2.1 - EFFECTS OF COFIRING LIGNIN AND BIOSOLIDS WITH COAL ON FIRESIDE PERFORMANCE AND COMBUSTION PRODUCTS}

\subsection{INTRODUCTION}

Electricity production from renewable biomass fuels such as wood residues, municipal solid waste (MSW), and agricultural residues accounts for approximately $1.5 \%$ of the total U.S. output (1). The U.S. government recently established a goal of tripling the nation's use of bioenergy by the year 2010 (2). The coal-burning electric power industry is primarily interested in opportunities to cost-effectively utilize renewable biomass fuels because of environmental concerns about air quality and global climate change.

The Orange Recycling and Ethanol Production Facility in Middletown, New York, is expected to produce ethanol in 2003 from MSW and biosolid feedstocks using Masada Resource Group's patented CES OxyNol ${ }^{\mathrm{TM}}$ process. The facility will have the capacity to process approximately 230,000 tons/year of MSW and 72,000 dry tons/year of biosolids to produce 9.5 million gallons/year of ethanol (3). Lignin residue, a by-product of ethanol production, will be recovered during the process for its energy value.

In this investigation, lignin and acidified biosolids were evaluated as supplemental fuels with a subbituminous coal blend for producing power at the Tennessee Valley Authority (TVA) Colbert Steam Plant. Colbert was identified as a model facility for evaluating the feasibility of co locating the ethanol production and coal-fired steam facilities. A bituminous coal-lignin blend was also tested under typical pulverized bituminous coal-firing conditions. A bituminous coal was selected to obtain a more generic view of the cofire concept and to evaluate how the type of coal affects cofire performance. The cofiring of relatively small proportions of lignin and/or acidified biosolids with coal may significantly affect combustion efficiency, boiler heat exchange surface slagging and fouling, $\mathrm{NO}_{\mathrm{x}}$ and $\mathrm{SO}_{\mathrm{x}}$ production, and fly ash and trace element emissions (4). These potential effects were evaluated in a pilot-scale $(550,000-\mathrm{Btu} / \mathrm{hr}[580-\mathrm{MJ} / \mathrm{hr}])$ combustion system. The effects of blending lignin and acidified biosolids with coal on fuel-handling and pulverization characteristics were also addressed.

\subsection{OBJECTIVES}

Primary objectives were to determine the effects of blending relatively small proportions (10 dry wt\%) of lignin and/or acidified biosolids with pulverized coals on:

- Fuel handling and pulverization.

- Slagging.

- Fouling.

- Fly ash properties (particle-size distribution, carbon content, major and minor element 
composition, and mineralogy).

- $\mathrm{SO}_{\mathrm{x}}, \mathrm{NO}_{\mathrm{x}}$, and $\mathrm{CO}_{2}$ emissions.

- Maximum trace element (As, $\mathrm{Cd}, \mathrm{Co}, \mathrm{Cr}, \mathrm{Hg}, \mathrm{Mn}, \mathrm{Ni}, \mathrm{Pb}, \mathrm{Sb}, \mathrm{Se}$, and $\mathrm{Cl}$ ) emissions.

\subsection{EXPERIMENTAL}

\subsection{Fuel Preparation and Combustion Test Matrix}

An $80 \mathrm{wt} \%$ Colorado-20 wt\% subbituminous Powder River Basin (PRB) coal blend from the TVA Colbert Steam Plant, hereafter referred to as the Colbert coal, and a bituminous Pittsburgh No. 8 coal were tested. Coal-lignin-biosolid fuels were blended on a dry weight basis and then homogenized by rotating in a tumbler for an hour. The two parent coals and fuel blends were pulverized remotely in a hammer mill to a standard combustion grind (i.e., $70 \%-80 \%$ of the particles $<200$ mesh). Fuel blend ratios and test conditions are summarized in Table 1 . Nine combustion tests were conducted to evaluate the effects of coal characteristics, blend mixture, and furnace exit gas temperature (FEGT) on combustion efficiency, boiler heat exchange surface slagging and fouling, and $\mathrm{NO}_{\mathrm{x}}$ and $\mathrm{SO}_{\mathrm{x}}$ production. The FEGT of $2200^{\circ} \mathrm{F}\left(1200^{\circ} \mathrm{C}\right)$ was chosen as a test parameter because it is representative of combustion conditions at Colbert Steam Plant Units 1-4 (5). The FEGT of $2350^{\circ} \mathrm{F}\left(1290^{\circ} \mathrm{C}\right)$ corresponds to periods of operational upsets experienced at the Colbert Steam Plant units and is typical of a pulverized bituminous coal-fired unit.

Table 1. Combustion Test Matrix

\begin{tabular}{lc}
\hline Coal-Lignin-Biosolid Blend Ratio, dry wt $\%$ & FEGT, ${ }^{\circ} \mathrm{F}\left({ }^{\circ} \mathrm{C}\right)$ \\
\hline $100^{\mathrm{a}}: 0: 0$ & $2200(1200)$ \\
$90^{\mathrm{a}}: 10: 0$ & $2200(1200)$ \\
$95^{\mathrm{a}}: 5: 0$ & $2200(1200)$ \\
$90^{\mathrm{a}}: 5: 5$ & $2200(1200)$ \\
$90^{\mathrm{a}}: 0: 10$ & $2200(1200)$ \\
$100^{\mathrm{b}}: 0: 0$ & $2350(1290)$ \\
$90^{\mathrm{b}}: 10: 0$ & $2350(1290)$ \\
$90^{\mathrm{a}}: 10: 0$ & $2350(1290)$ \\
$100^{\mathrm{a}}: 0: 0$ & $2350(1290)$ \\
\hline $80 \mathrm{w} \% \mathrm{C}$
\end{tabular}

a $80 \mathrm{wt} \%$ Colorado- $20 \mathrm{wt} \%$ PRB coal blend.

${ }^{\mathrm{b}}$ Pittsburgh No. 8 coal. 


\subsection{Combustion Testing}

A 550,000-Btu/hr (580-MJ/hr) combustion system, termed the combustion test furnace (CTF), was used to evaluate the effects of cofiring relatively small proportions of lignin and/or acidified biosolid with coal on combustion efficiency, boiler heat exchange surface slagging and fouling, and $\mathrm{NO}_{\mathrm{x}}$ and $\mathrm{SO}_{\mathrm{x}}$ production. An isometric drawing of the CTF is shown in Figure 1. For scale, the refractory-lined combustor in Figure 1 is 30 in. $(76 \mathrm{~cm})$ in diameter and $8 \mathrm{ft}(2.4 \mathrm{~m})$ high.

Prior to each test, an appropriate pulverized fuel (Table 1) was transported to a microprocessor-controlled weight loss feeder. The fuel was then transported via a gravimetric feeder into the venturi section of the primary air line to the burner. Heated secondary air was introduced through an annular section surrounding the burner. Heated tertiary air was injected through two tangential ports located in the furnace wall about $1 \mathrm{ft}(30 \mathrm{~cm})$ above the burner cone. The primary, secondary, and tertiary air accounted for $10 \%, 30 \%$, and $60 \%$, respectively, of the total air volume in the CTF.

Flue gas exits the furnace via a 10-in. $(25-\mathrm{cm})$-square duct that is also refractory-lined. A vertical probe bank is located in this duct and designed to simulate superheater surfaces in a commercial boiler. The probe bank consists of three 1.66-in. $(4.22-\mathrm{cm})$-outside-diameter, steamcooled, stainless steel (Type 304) tubes. These tubes are attached to a hinged door to facilitate

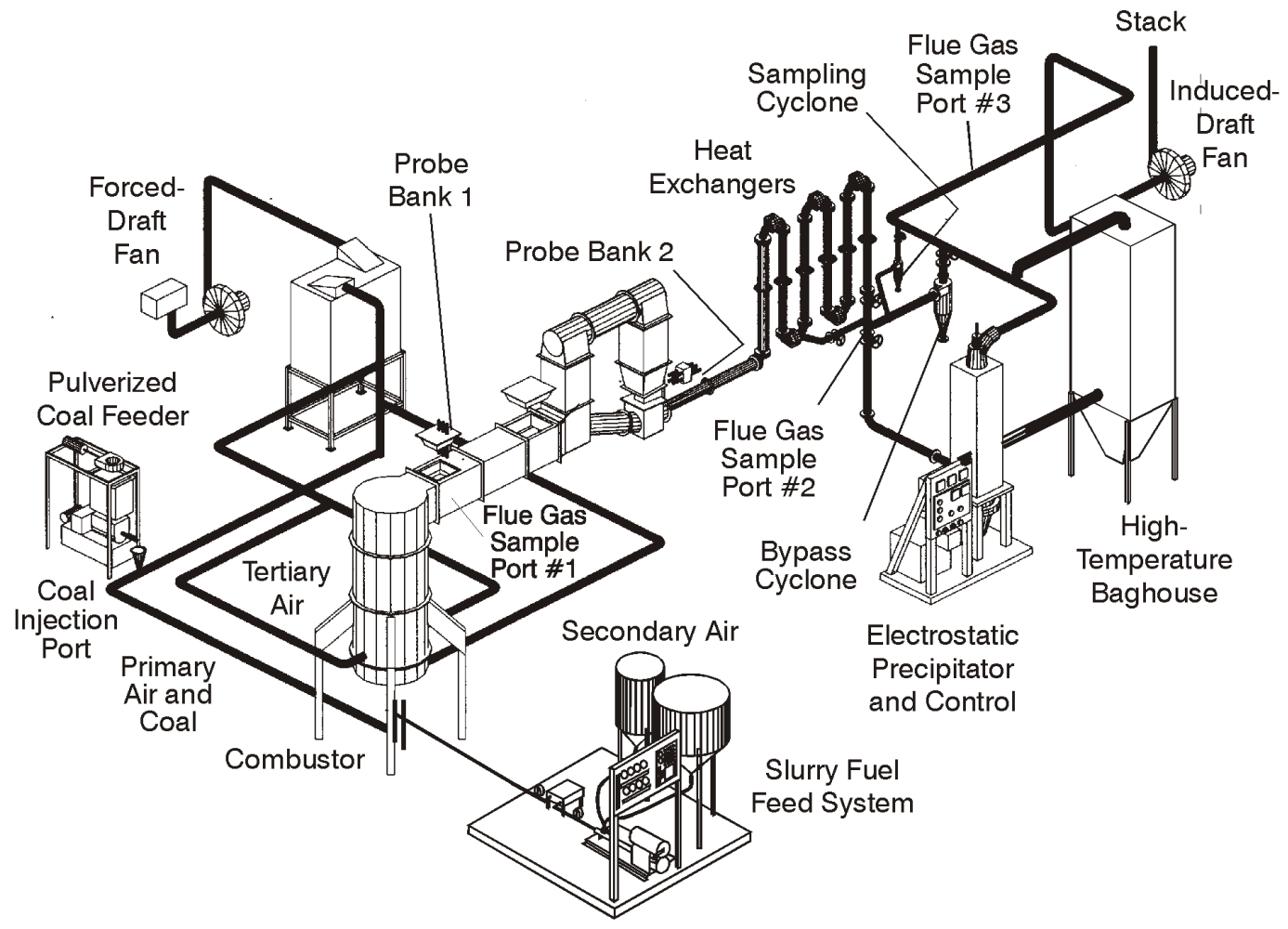

Figure 1. CTF and auxiliary systems. 
inspection and cleaning. Each tube is equipped with two thermocouples embedded in its upstream edge to measure metal temperature. A thermocouple on each tube is attached to a temperature recorder-controller that regulates steam flow to achieve a surface metal temperature of $1000^{\circ} \mathrm{F}$ $\left(540^{\circ} \mathrm{C}\right)$. Gas velocity between the tubes was typically about $25 \mathrm{ft} / \mathrm{s}(7.6 \mathrm{~m} / \mathrm{s})$ when fuels were fired at a rate sufficient to achieve a $2200^{\circ}$ or $2350^{\circ} \mathrm{F}\left(1200^{\circ}\right.$ or $\left.1290^{\circ} \mathrm{C}\right)$ gas temperature entering the probe bank. After exiting the probe duct, the flue gas passed through a series of water-cooled heat exchangers and into an electrostatic precipitator (ESP).

\subsubsection{Test Method}

The relative fouling severity of the test fuels was determined by burning each fuel using similar conditions. The duration of each test involved an 8-hour preheat on natural gas followed by $5.25 \mathrm{hr}$ of actual fuel firing.

The fuel feed rate was adjusted to keep the flue gas temperature entering the upper duct to the probe bank at $2200^{\circ} \mathrm{F}\left(1200^{\circ} \mathrm{C}\right)$ or $2350^{\circ} \mathrm{F}\left(1290^{\circ} \mathrm{C}\right)$, with $20 \%$ excess air. Fuel samples were taken periodically to form a composite sample for each test. Flue gas $\mathrm{O}_{2}, \mathrm{CO}_{2}, \mathrm{NO}_{\mathrm{x}}, \mathrm{CO}$, and $\mathrm{SO}_{2}$ concentrations were continuously monitored by on-line recording analyzers.

After each test, the probe door was carefully opened, and the deposit was photographed. The deposit was then removed from the probes in two fractions, an inner layer and an outer sintered deposit, and each was weighed and analyzed separately.

The weight of ash deposited on the probe bank during each test was used to rank relative fouling potential. To ensure that the pilot-scale test results were meaningful for evaluation of ashfouling potential in full-scale utility boilers, calibration tests were previously conducted with coals known to produce low and high fouling when used in utility boilers. Comparisons of ash fouling have been made from tests conducted at a number of power stations throughout the United States, including Monticello (Texas Utilities), Big Brown (Texas Utilities), Four Corners (Arizona Public Service Company), St. Clair (Detroit Edison Company), Jim Bridger (Pacific Power and Light), Big Stone (Otter Tail Power Company), Leland Olds (Basin Electric Power Cooperative), and San Miguel (San Miguel Electric Cooperative). Based on these tests, the ash deposit buildup rate on the probe bank was found to be a good indicator of fouling potential. The relationship between ash deposit weight and a fuel's fouling potential is generally categorized as indicated in Table 2 .

In addition to weighing the probe bank deposits, the ash collected in the heat exchanger (HX), duct work, and ESP were weighed. The total entrained ash is equivalent to the summation of deposit, $\mathrm{HX}$, duct, and ESP ash weights. It was impractical to obtain a direct measurement of the bottom ash because it generally slagged onto metal and preexisting slag surfaces. Thus the amount of bottom ash was estimated by subtracting the total entrained ash weight from the total ash fed into the combustion system for a given test. 


\section{Table 2. Ranking Scheme for Fouling Potential}

\begin{tabular}{lc}
\hline Deposit Weight, g & Relative Fouling Potential \\
\hline $0-150$ & Low \\
$150-300$ & Medium \\
$>300$ & High \\
\hline
\end{tabular}

\subsubsection{Deposit Strength Tests}

Ash deposit weight from the probe bank has proven to be a good indicator of fouling potential for most fuels tested in the CTF. Heavy deposits in the 5.25-hr test indicate high deposition rates, which can usually be related to potential ash-fouling problems in utility boilers. However, the deposition rate does not provide an indication of the ease of removal of deposits by sootblowing. Deposit strength was assessed during removal of deposits from the probe bank. Two components of deposit strength were evaluated: the strength of the deposit probe bond and the hardness of the bulk deposit.

\subsection{Sampling and Analysis}

Fuels, fly ashes, and deposits were sampled and characterized using primarily U.S. Environmental Protection Agency (EPA) and American Society for Testing and Materials (ASTM) methods as defined in Table 3. In addition, samples of aerodynamically sized fly ash were collected from the ESP inlet of the combustion system using a 5-stage cascade cyclone sampler (6). Nominal $50 \%$ cutoff diameters $\left(\mathrm{D}_{50}\right)$ for the cyclone stages were $0.6,1.4,2.0,3.9$, and $7.0 \mu \mathrm{m}$, based on the actual flue gas conditions (temperature, pressure, gas composition, etc.). Chemical fractionation and computer-controlled scanning electron microscopy (CCSEM) methods were also used to provide a more comprehensive analysis of the fuel inorganic components. These two methods are described in Sections 3.3.1 and 3.3.2 of this report.

\subsubsection{Chemical Fractionation}

In addition to the standard methods presented in Table 3, the fuels were analyzed using a chemical fractionation method to evaluate elemental distributions among different organic and inorganic components. A representative 40-80-g sample of fuel was ground to -200 mesh and vacuum oven-dried to constant weight. A portion of each fuel was analyzed for ash content and major and minor elements by wavelength-dispersive $\mathrm{x}$-ray fluorescence spectroscopy (WDXRF) (ASTM D4326). The fuels were then subjected to the successive extraction treatments summarized in Table 4. After each extraction, the fuel mixture was filtered, and a portion of the residue was analyzed for ash content and major and minor elements by WDXRF. The analysis data were then utilized in mass balance calculations to determine the elemental losses, relative to the unfractionated fuel, resulting from each extraction. Elements removed by $\mathrm{H}_{2} \mathrm{O}$ are primarily associated with watersoluble minerals (e.g., alkali halides). Exchangeable ions, principally elements associated with salts 


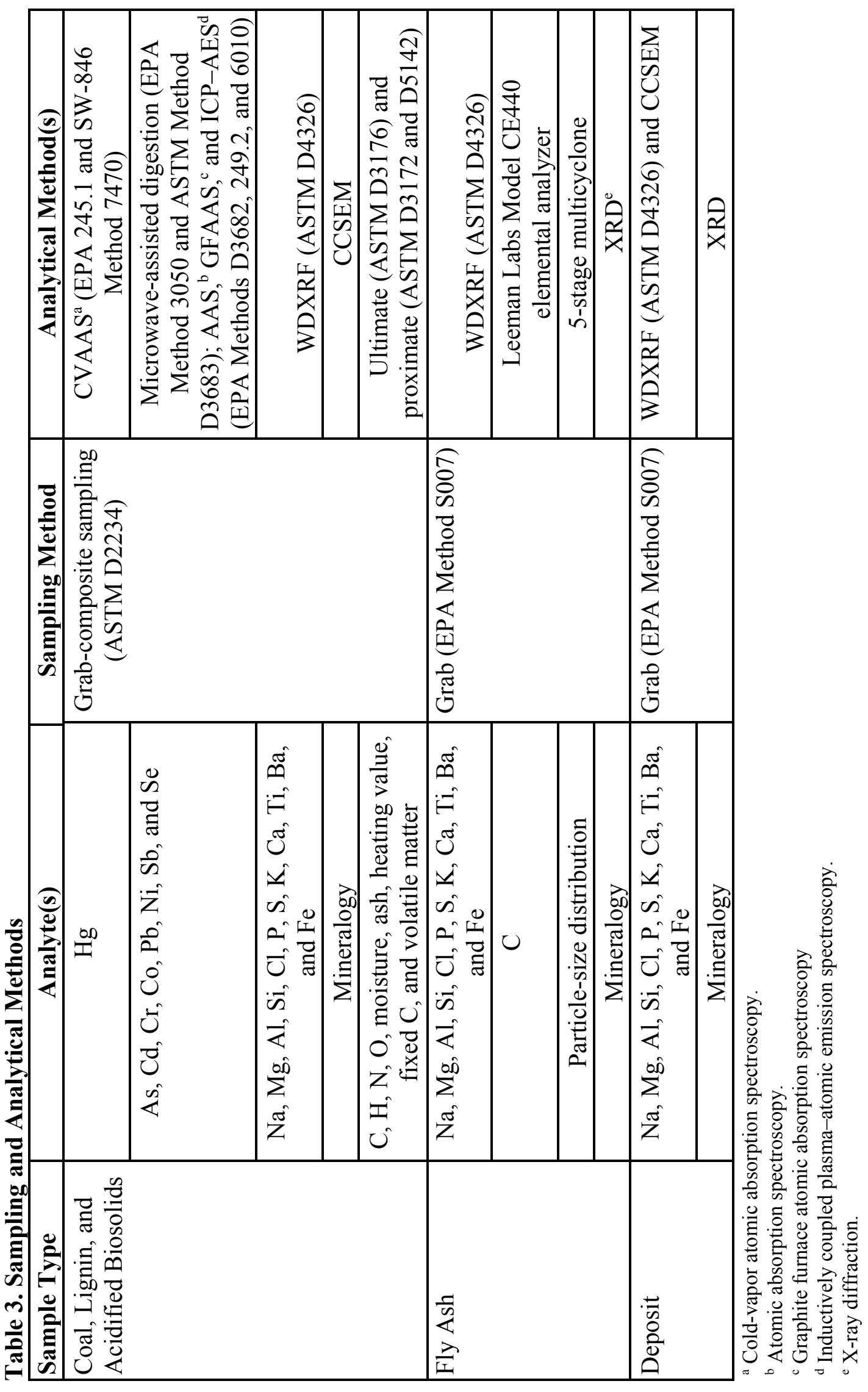


Table 4. Chemical Fractionation Protocol

\begin{tabular}{lccc}
\hline Reagent & Quantity, $\mathrm{mL}$ & Temperature, ${ }^{\circ} \mathrm{C}$ & Duration, $\mathrm{hr}$ \\
\hline $\mathrm{H}_{2} \mathrm{O}$ & 100 & $\sim 25$ & 24 \\
$1 \mathrm{M} \mathrm{NH}_{4} \mathrm{OAc}^{\mathrm{a}}$ & 100 & 70 & 24 \\
$1 \mathrm{M} \mathrm{HCl}^{\mathrm{b}}$ & 100 & 70 & 24 \\
\hline${ }^{\mathrm{a}}$ Extraction performed in triplicate. & & \\
${ }^{\mathrm{b}}$ Extraction performed in duplicate. & &
\end{tabular}

of organic acids and clay minerals, are removed by ammonium acetate $\left(\mathrm{NH}_{4} \mathrm{OAc}\right)$. Hydrochloric acid $(\mathrm{HCl})$ removes elements associated with acid-soluble minerals (carbonates, oxides, and metastable sulfides) and organic coordination complexes, such as carboxylate groups on coal surfaces. Elements remaining in the final residue are presumably associated with insoluble silicate and sulfide minerals.

\subsubsection{Computer-Controlled Scanning Electron Microscopy}

Fuel samples were embedded in carnauba wax, cross-sectioned, polished (ASTM Standard Practice D2797), and sputter-coated with carbon. CCSEM analyses on the prepared coal samples were performed using a JEOL JSM-5800 scanning electron microscope (SEM) equipped with a Noran Instruments Voyager x-ray analysis and automation system. Mineral detection and sizing were performed using digital image analysis techniques. Mineral identification and quantification were performed using the procedures described by Galbreath and others (7).

\subsection{RESULTS}

\subsection{Fuel Handling and Pulverization}

On an as-received basis, the acidified biosolids contained approximately $69.5 \mathrm{wt} \% \mathrm{H}_{2} \mathrm{O}$. An attempt to blend $10 \mathrm{wt} \%$ of the as-received acidified biosolids with $90 \mathrm{wt} \%$ of the Colbert coal blend was unsuccessful because the sludge was pasty, resulting in the formation of relatively large coal-biosolid balls during the tumbling process. The coal-biosolid balls were too large to be fed into the hammer mill. After air-drying the biosolids to 26.5 and $38.4 \mathrm{wt} \% \mathrm{H}_{2} \mathrm{O}$, no homogenization or feed problems were encountered during the tumbling and hammer-milling processes. The lignin, at 40.9 as-received $w t \% \mathrm{H}_{2} \mathrm{O}$, did not require drying prior to homogenization and pulverization. The fuel-handling and pulverization characteristics of the lignin and acidified biosolids were similar at equivalent $\mathrm{H}_{2} \mathrm{O}$ contents of about $40 \mathrm{wt} \%$.

Under Masada's current process design, biosolids fuel destined for cofiring with coal will be dried to a lower moisture to enhance fuel value and handling and reduce transportation costs. Based on these fuel-handling and pulverization tests, dried biosolid and lignin fuels should not present handling or fuel homogeneity problems as a blending component with coal. 


\subsection{Fuel Chemical and Mineralogical Compositions}

\subsubsection{Proximate and Ultimate Analyses}

Parent fuel proximate and ultimate analysis results are presented in Tables 5 and 6 , respectively. Ash contents of the four fuels are very similar. The lignin and acidified biosolids are characterized by possessing higher moisture contents and lower carbon and heating values relative to the coals. Lignin possesses the highest sulfur content. While the lignin composition is generally representative of that expected from the Masada process, the lignin sulfur content is artificially elevated (8). The elevated sulfur content results from limitations in mimicking the commercial process at the pilot scale. Masada's extensive bench- and pilot-scale testing of its process has demonstrated that lower sulfur concentrations can be achieved through a more extensive washing and drying of the lignin in a dewatering device that is more efficient than the plate and frame filter utilized by TVA for lignin production. Masada anticipates sulfur concentrations of $\leq 3.57 \mathrm{wt} \%$ on a dry basis, based on a conservative evaluation of lignin-washing efficiency in a commercial filter unit. A typical ultimate analysis, provided by Hazen Research in Golden, Colorado, for a lignin sample processed under conditions similar to the commercial design is $47.4 \mathrm{wt} \%$ carbon, $4.47 \mathrm{wt} \%$ hydrogen, $0.60 \mathrm{wt} \%$ nitrogen, $2.47 \mathrm{wt} \%$ sulfur, $21.8 \mathrm{wt} \%$ ash, $28.2 \mathrm{wt} \%$ oxygen, and $42.6 \mathrm{wt} \%$ moisture.

Table 5. Fuel Proximate Analysis Results, as-received

\begin{tabular}{lcccc}
\hline Analysis Parameters & Colbert Coal Blend & Pittsburgh No. 8 & Lignin & Biosolids \\
\hline Moisture, wt $\%$ & 8.10 & 2.10 & 40.9 & 68.8 \\
Volatile Matter, wt $\%$ & 38.6 & 35.9 & 34.7 & 17.1 \\
Fixed Carbon, wt $\%$ & 41.2 & 50.0 & 11.0 & 2.73 \\
Ash, wt $\%$ & 12.2 & 12.0 & 13.4 & 11.3 \\
$\mathrm{HHV}, \mathrm{Btu} / \mathrm{lb}$ & 10,700 & 13,320 & 4130 & 1810 \\
\hline
\end{tabular}

Table 6. Fuel Ultimate Analysis Results, as-received wt\%

\begin{tabular}{lcccc}
\hline Analysis Parameters & Colbert Coal Blend & Pittsburgh No. 8 & Lignin & Biosolids \\
\hline Carbon & 62.2 & 72.3 & 24.4 & 9.94 \\
Hydrogen $^{\mathrm{a}}$ & 4.25 & 4.10 & 2.26 & 1.43 \\
Nitrogen & 1.37 & 1.30 & 0.36 & 1.50 \\
Sulfur & 0.49 & 1.50 & 3.19 & 0.82 \\
Ash & 12.2 & 12.0 & 13.4 & 11.3 \\
Oxygen $^{\text {a }}$ & 11.4 & 6.70 & 15.4 & 6.17 \\
Total Moisture & 8.10 & 2.10 & 40.9 & 68.8 \\
\hline
\end{tabular}

${ }^{a}$ Hydrogen and oxygen do not include $\mathrm{H}$ and $\mathrm{O}$ in sample moisture. 
Proximate and ultimate analysis results for the Colbert coal parent and fuel blends fed into the CTF are presented in Tables 7 and 8, respectively. As expected from the parent fuel analyses in Tables 5 and 6, the primary effects of blending lignin with the Colbert coal blend were to increase moisture and sulfur and reduce carbon and nitrogen concentrations. The blending of biosolids with the Colbert coal blend increased moisture concentration and reduced carbon concentration and higher heating value (HHV).

Proximate and ultimate analysis results for the Pittsburgh No. 8 coal parent and fuel blend fed into the CTF are presented in Tables 9 and 10, respectively. Similar to the Colbert coal-lignin blends (Tables 7 and 8), the primary effects of blending lignin with the Pittsburgh No. 8 coal were to increase moisture and sulfur and reduce carbon and nitrogen concentrations.

\subsubsection{Major and Minor Element Compositions}

Compositions of the parent fuels are compared in Table 11. Although the coals have similar silica $\left(\mathrm{SiO}_{2}\right)$ and alumina $\left(\mathrm{Al}_{2} \mathrm{O}_{3}\right)$ contents, the Colbert coal blend is characterized by possessing greater alkaline-earth $(\mathrm{CaO}$ and $\mathrm{MgO})$ and alkali $\left(\mathrm{Na}_{2} \mathrm{O}+\mathrm{K}_{2} \mathrm{O}\right)$ metals but less ferric oxide $\left(\mathrm{Fe}_{2} \mathrm{O}_{3}\right)$

Table 7. Test Fuel Proximate Analysis Results, as-received

\begin{tabular}{lccccccc}
\hline & \multicolumn{7}{c}{ Colbert Coal-Lignin-Biosolid Blend Ratio } \\
\cline { 2 - 7 } Analysis Parameters & $100: 0: 0^{\mathrm{a}}$ & $100: 0: 0^{\mathrm{b}}$ & $95: 5: 0^{\mathrm{a}}$ & $90: 10: 0^{\mathrm{a}}$ & $90: 10: 0^{\mathrm{b}}$ & $95: 5: 5^{\mathrm{a}}$ & $90: 0: 10^{\mathrm{a}}$ \\
\hline Moisture, wt\% & 8.40 & 6.40 & 9.10 & 10.1 & 8.80 & 10.5 & 11.0 \\
Volatile Matter, w\% & 39.6 & 40.6 & 40.5 & 40.7 & 40.2 & 40.1 & 40.4 \\
Fixed Carbon, wt\% & 42.3 & 44.5 & 40.8 & 39.2 & 41.0 & 38.8 & 38.3 \\
Ash, wt\% & 9.74 & 8.42 & 9.65 & 10.1 & 9.98 & 10.6 & 10.3 \\
Heating Value, Btu/lb & 11,260 & 11,660 & 11,250 & 10,810 & 11,410 & 10,850 & 10,470 \\
\hline
\end{tabular}

${ }^{\mathrm{a}}$ Tested at an FEGT of $2200^{\circ} \mathrm{F}\left(1200^{\circ} \mathrm{C}\right)$.

${ }^{\mathrm{b}}$ Tested at an FEGT of $2350^{\circ} \mathrm{F}\left(1290^{\circ} \mathrm{C}\right)$.

Table 8. Test Fuel Ultimate Analysis Results, as-received wt\%

\begin{tabular}{lccccccc}
\hline & \multicolumn{7}{c}{ Colbert Coal-Lignin-Biosolid Blend Ratio } \\
\cline { 2 - 7 } Analysis & $100: 0: 0^{\mathrm{a}}$ & $100: 0: 0^{\mathrm{b}}$ & $95: 5: 0^{\mathrm{a}}$ & $90: 10: 0^{\mathrm{a}}$ & $90: 10: 0^{\mathrm{b}}$ & $95: 5: 5^{\mathrm{a}}$ & $90: 0: 10^{\mathrm{a}}$ \\
\hline Parameters & 64.0 & 66.6 & 63.8 & 61.6 & 63.7 & 60.8 & 58.9 \\
Carbon $_{\text {Hydrogen }}^{\mathrm{c}}$ & 4.41 & 4.51 & 4.42 & 4.28 & 4.00 & 4.57 & 4.43 \\
Nitrogen $_{\text {Sulfur }}$ & 1.30 & 1.48 & 1.25 & 1.15 & 1.22 & 10.4 & 1.87 \\
Ash & 0.42 & 0.53 & 0.52 & 0.62 & 1.00 & 0.50 & 0.50 \\
Oxygen $^{\mathrm{c}}$ & 9.74 & 8.42 & 9.65 & 10.1 & 9.98 & 10.6 & 10.3 \\
Total Moisture & 11.7 & 12.0 & 11.3 & 12.1 & 10.6 & 2.68 & 13.1 \\
\hline
\end{tabular}

${ }^{\mathrm{a}}$ Tested at an FEGT of $2200^{\circ} \mathrm{F}\left(1200^{\circ} \mathrm{C}\right)$.

${ }^{\mathrm{b}}$ Tested at an FEGT of $2350^{\circ} \mathrm{F}\left(1290^{\circ} \mathrm{C}\right)$.

${ }^{\mathrm{c}}$ Hydrogen and oxygen do not include $\mathrm{H}$ and $\mathrm{O}$ in sample moisture. 
Table 9. Test Fuel Proximate Analysis Results, as-received

\begin{tabular}{lcc} 
& \multicolumn{1}{c}{ Pittsburgh No. 8 Coal-Lignin Blend Ratio } \\
\cline { 2 - 3 } Analysis Parameters & $100: 0$ & $90: 10$ \\
\hline Moisture, wt $\%$ & 2.20 & 3.10 \\
Volatile Matter, wt $\%$ & 36.9 & 40.3 \\
Fixed Carbon, wt $\%$ & 53.8 & 48.9 \\
Ash, wt $\%$ & 7.09 & 7.62 \\
Heating Value, Btu/lb & 13,230 & 12,770 \\
\hline
\end{tabular}

Table 10. Test Fuel Ultimate Analysis Results, as-received wt\%

\begin{tabular}{lcc}
\hline & Pittsburgh No. 8 Coal-Lignin Blend Ratio \\
\cline { 2 - 3 } Analysis Parameters & $100: 0$ & $90: 10$ \\
\hline Carbon & 74.8 & 72.0 \\
Hydrogen $^{\mathrm{a}}$ & 4.87 & 4.84 \\
Nitrogen & 2.29 & 1.62 \\
Sulfur & 0.90 & 1.28 \\
Ash & 7.09 & 7.62 \\
Oxygen $^{\mathrm{a}}$ & 7.82 & 9.49 \\
Total Moisture $^{\text {CHydrogen and }}$ & 2.20 & 3.10 \\
\hline
\end{tabular}

${ }^{\mathrm{a}}$ Hydrogen and oxygen do not include $\mathrm{H}$ and $\mathrm{O}$ in sample moisture.

relative to the Pittsburgh No. 8 coal. The lignin is distinguished from the coals by possessing higher concentrations of $\mathrm{TiO}_{2}, \mathrm{CaO}$, and $\mathrm{SO}_{3}$ and lower concentrations of $\mathrm{SiO}_{2}, \mathrm{Al}_{2} \mathrm{O}_{3}, \mathrm{Fe}_{2} \mathrm{O}_{3}$, and $\mathrm{K}_{2} \mathrm{O}$. The acidified biosolids are characterized by higher concentrations of $\mathrm{P}_{2} \mathrm{O}_{5}$ relative to the other fuels.

Chemical compositions of the parent coals and fuel blends that were fed into the combustion system are compared in Tables 12 and 13. As expected from the parent fuel compositions in Table 11 , the blending of lignin with the coals generally increases $\mathrm{TiO}_{2}, \mathrm{CaO}$, and $\mathrm{SO}_{3}$ concentrations and reduces $\mathrm{SiO}_{2}$ concentrations. The primary effect of biosolids blending is to increase $\mathrm{P}_{2} \mathrm{O}_{5}$ concentration.

\subsubsection{Chemical Fractionation Analyses}

Chemical fractionation analyses were performed on the Colbert coal blend, lignin, and biosolid fuels. Chemical fractionation was not performed on the Pittsburgh No. 8 coal because the inorganic components of bituminous coals generally occur as discrete mineral grains that are insoluble in $\mathrm{H}_{2} \mathrm{O}$, 
Table 11. Comparison of Parent Fuel Chemical Compositions, ash wt\%

\begin{tabular}{lcccc}
\hline Elemental Oxide & Colbert Coal Blend & Pittsburgh No. 8 & Lignin & Biosolids \\
\hline $\mathrm{SiO}_{2}$ & 53.5 & 52.1 & 42.4 & 16.2 \\
$\mathrm{Al}_{2} \mathrm{O}_{3}$ & 20.7 & 27.1 & 18.2 & 13.8 \\
$\mathrm{Fe}_{2} \mathrm{O}_{3}$ & 4.78 & 14.9 & 2.44 & 5.63 \\
$\mathrm{TiO}_{2}$ & 0.84 & 1.14 & 2.81 & 1.41 \\
$\mathrm{BaO}$ & 0.17 & $\mathrm{NA}^{\mathrm{a}}$ & 0.05 & $\mathrm{NA}$ \\
$\mathrm{P}_{2} \mathrm{O}_{5}$ & 0.52 & 0.58 & 0.58 & 38.7 \\
$\mathrm{CaO}$ & 8.82 & 3.10 & 16.2 & 11.8 \\
$\mathrm{MgO}$ & 3.00 & 1.12 & 1.43 & 4.30 \\
$\mathrm{Na}$ & 1.87 & 0.52 & 1.02 & 0.66 \\
$\mathrm{~K}_{2} \mathrm{O}$ & 1.62 & 1.85 & 0.53 & 0.76 \\
$\mathrm{SO}_{3}$ & 5.75 & 2.70 & 16.9 & 5.43 \\
$\mathrm{Cl}$ & 0.02 & $\mathrm{NA}$ & $<0.02$ & $\mathrm{NA}$ \\
Total & 101.6 & 105 & 102.6 & 98.8 \\
\hline${ }^{\mathrm{N}} \mathrm{Not}$ analyzed & & & &
\end{tabular}

${ }^{\mathrm{a}}$ Not analyzed.

Table 12. Baseline Colbert Coal and Fuel Blend Chemical Compositions, ash wt\%

\begin{tabular}{lccccccc}
\hline & \multicolumn{7}{c}{ Colbert Coal-Lignin-Biosolid Blend Ratio } \\
\cline { 2 - 8 } Elemental Oxide & $100: 0: 0^{\mathrm{a}}$ & $100: 0: 0^{\mathrm{b}}$ & $95: 5: 0^{\mathrm{a}}$ & $90: 10: 0^{\mathrm{a}}$ & $90: 10: 0^{\mathrm{b}}$ & $95: 5: 5^{\mathrm{a}}$ & $90: 0: 10^{\mathrm{a}}$ \\
\hline $\mathrm{SiO}_{2}$ & 49.4 & 46.9 & 48.1 & 46.6 & 44.8 & 44.6 & 40.0 \\
$\mathrm{Al}_{2} \mathrm{O}_{3}$ & 21.5 & 22.2 & 21.6 & 21.5 & 20.8 & 21.2 & 20.9 \\
$\mathrm{Fe}_{2} \mathrm{O}_{3}$ & 5.54 & 6.31 & 5.41 & 5.23 & 8.05 & 5.98 & 6.48 \\
$\mathrm{TiO}_{2}$ & 0.91 & 0.91 & 1.1 & 1.31 & 1.20 & 1.21 & 1.22 \\
$\mathrm{P}_{2} \mathrm{O}_{5}$ & 0.63 & 0.72 & 0.63 & 0.66 & 0.41 & 4.46 & 8.73 \\
$\mathrm{CaO}$ & 9.13 & 8.87 & 10.1 & 10.8 & 8.92 & 10.5 & 10.7 \\
$\mathrm{MgO}$ & 2.31 & 2.13 & 2.08 & 2.14 & 2.25 & 2.45 & 2.94 \\
$\mathrm{Na}_{2} \mathrm{O}$ & 1.83 & 1.90 & 1.83 & 1.72 & 1.54 & 1.66 & 1.63 \\
$\mathrm{~K}_{2} \mathrm{O}$ & 1.13 & 0.98 & 0.95 & 0.93 & 1.16 & 0.96 & 0.95 \\
$\mathrm{SO}_{3}$ & 8.29 & 10.5 & 10.0 & 11.4 & 10.5 & 9.30 & 7.98 \\
$\mathrm{Total}$ & 100.7 & 101.4 & 101.8 & 102.3 & 99.7 & 102.2 & 101.6 \\
\hline
\end{tabular}

${ }^{\mathrm{a}} \mathrm{FEGT}=2200^{\circ} \mathrm{F}\left(1200^{\circ} \mathrm{C}\right)$.

${ }^{\mathrm{b}} \mathrm{FEGT}=2350^{\circ} \mathrm{F}\left(1290^{\circ} \mathrm{C}\right)$. 
Table 13. Baseline Pittsburgh No. 8 Coal and Fuel Blend Chemical Compositions, ash wt\%

\begin{tabular}{|c|c|c|}
\hline \multirow[b]{2}{*}{ Elemental Oxide } & \multicolumn{2}{|c|}{ Pittsburgh No. 8 Coal-Lignin Blend Ratio } \\
\hline & 100:0 & $90: 10$ \\
\hline $\mathrm{SiO}_{2}$ & 49.6 & 47.4 \\
\hline $\mathrm{Al}_{2} \mathrm{O}_{3}$ & 25.8 & 28.1 \\
\hline $\mathrm{Fe}_{2} \mathrm{O}_{3}$ & 14.1 & 8.06 \\
\hline $\mathrm{TiO}_{2}$ & 1.09 & 1.87 \\
\hline $\mathrm{P}_{2} \mathrm{O}_{5}$ & 0.55 & 0.22 \\
\hline $\mathrm{CaO}$ & 2.95 & 6.61 \\
\hline $\mathrm{MgO}$ & 1.07 & 1.28 \\
\hline $\mathrm{Na}_{2} \mathrm{O}$ & 0.49 & 0.91 \\
\hline $\mathrm{K}_{2} \mathrm{O}$ & 1.77 & 1.88 \\
\hline $\mathrm{SO}_{3}$ & 2.57 & 7.52 \\
\hline Total & 100.0 & 103.8 \\
\hline
\end{tabular}

$\mathrm{NH}_{4} \mathrm{OAc}$, or $\mathrm{HCl}$. Therefore, chemical fractionation analyses of bituminous coals are generally uninformative. Chemical fractionation results for the Colbert coal blend, lignin, and biosolid fuels are presented in Figures 2-4, respectively. Certain elements (e.g., Si, Al, and Ti) are not included in Figures $2-4$ because they were not removed significantly during the extraction procedure. These insoluble elements are generally associated with the aluminosilicate (e.g., kaolinite $\left.\left[\mathrm{Al}_{2} \mathrm{Si}_{2} \mathrm{O}_{5}(\mathrm{OH})_{4}\right]\right)$,

silicate (e.g., quartz $\left[\mathrm{SiO}_{2}\right]$ ), and oxide (e.g., rutile $\left[\mathrm{TiO}_{2}\right]$ ) mineral components of coal.

Water-soluble compounds are not abundant, generally $<20 \%$ removal, in the Colbert coal blend (Figure 2). The coal blend, however, contains relatively high proportions of exchangeable $\mathrm{Ca}$, $\mathrm{Mg}, \mathrm{Na}$, and $\mathrm{S}$ which are presumably associated with the salts of organic acids and/or clay minerals. Most of the $\mathrm{Fe}$ and $\mathrm{P}$ in Colbert coal is associated with $\mathrm{HCl}$-soluble minerals and/or elements associated with organic coordination complexes.

Relatively high proportions of water-soluble Fe-, P-, and Na-containing compounds exist in the lignin (Figure 3). The lignin possesses high proportions, $70 \%-80 \%$ removal, of $\mathrm{NH}_{4} \mathrm{OAc}$-soluble $\mathrm{Ca}$ and $\mathrm{S}$ which may be associated with gypsum $\left(\mathrm{CaSO}_{4} \cdot 2 \mathrm{H}_{2} \mathrm{O}\right)$. HCl-soluble phases are generally insignificant, $<20 \%$ removal, in the lignin. 


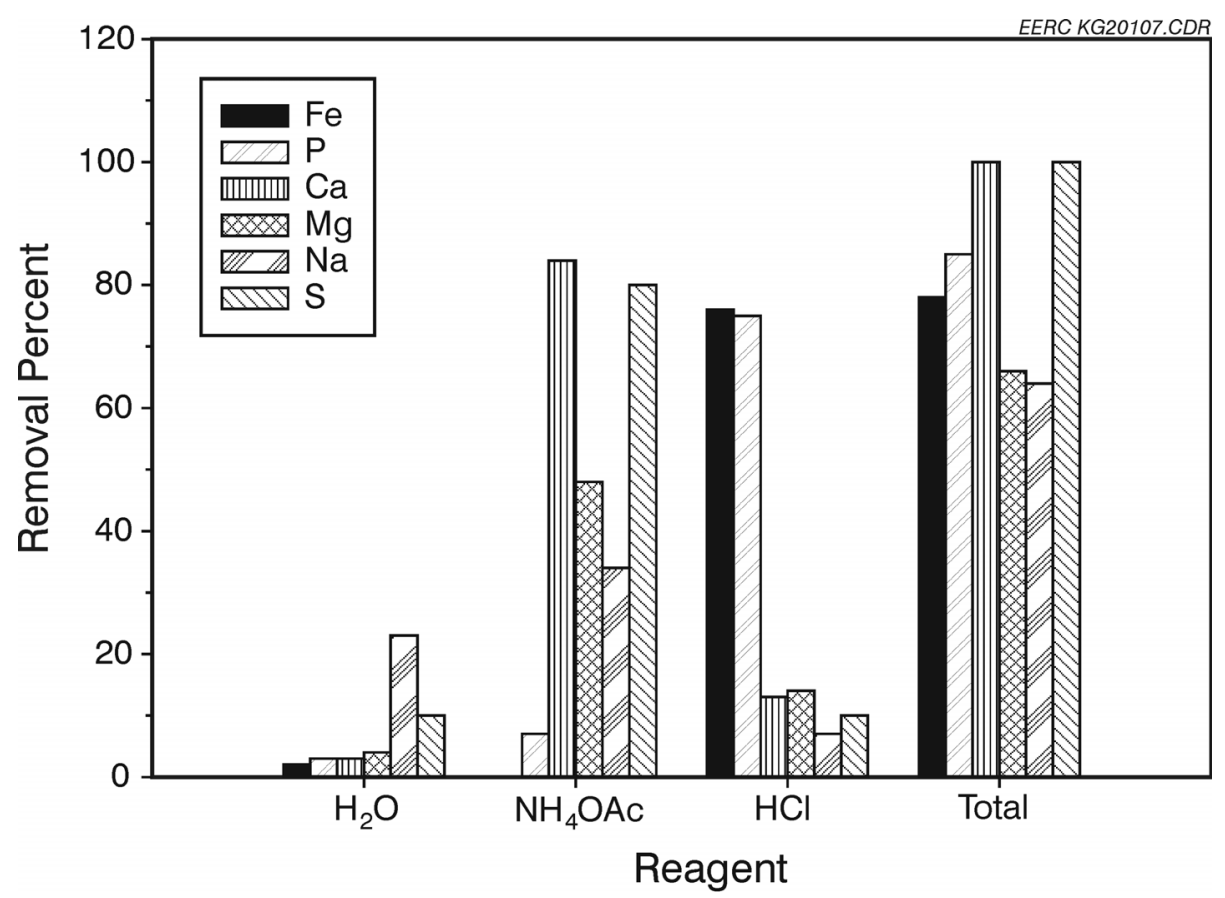

Figure 2. Colbert coal blend chemical fractionation results.

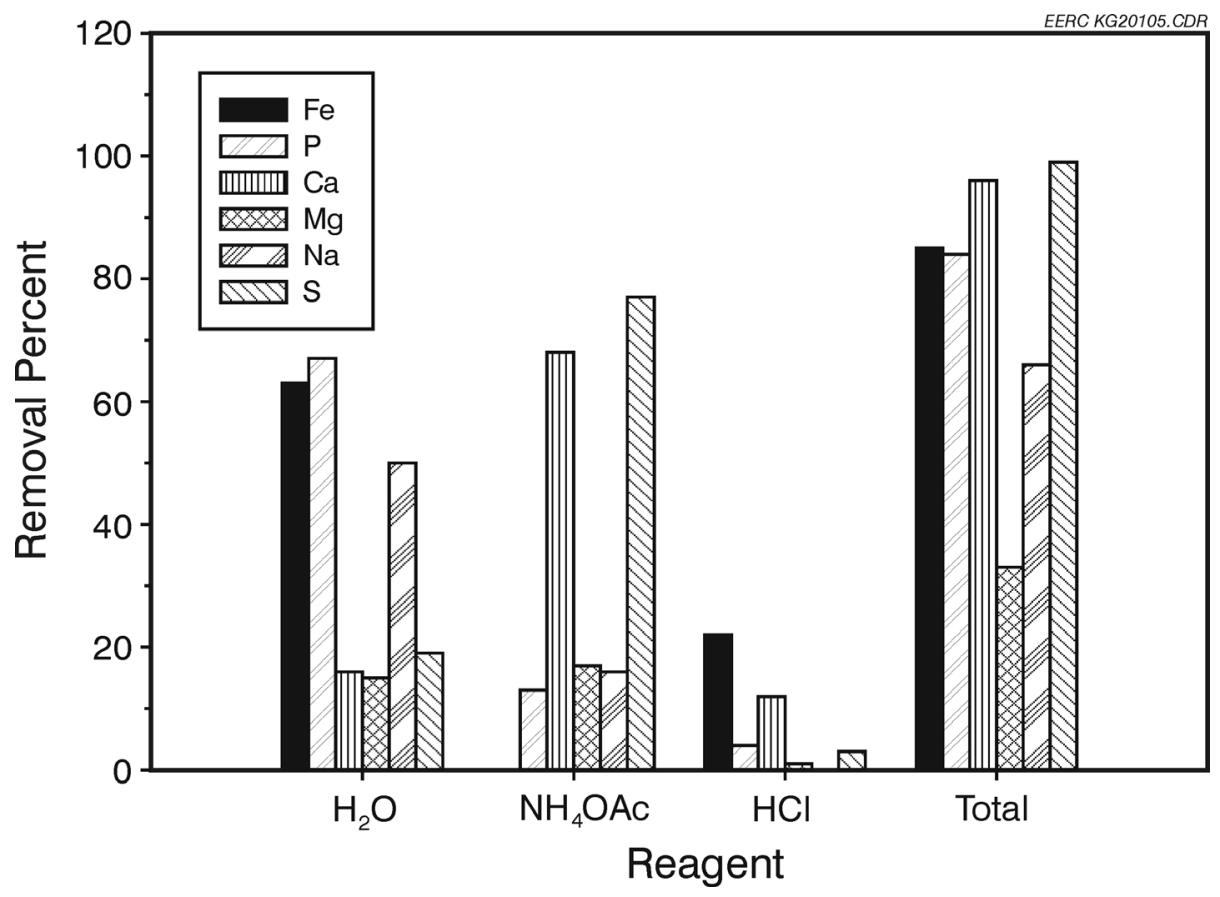

Figure 3. Lignin chemical fractionation results. 


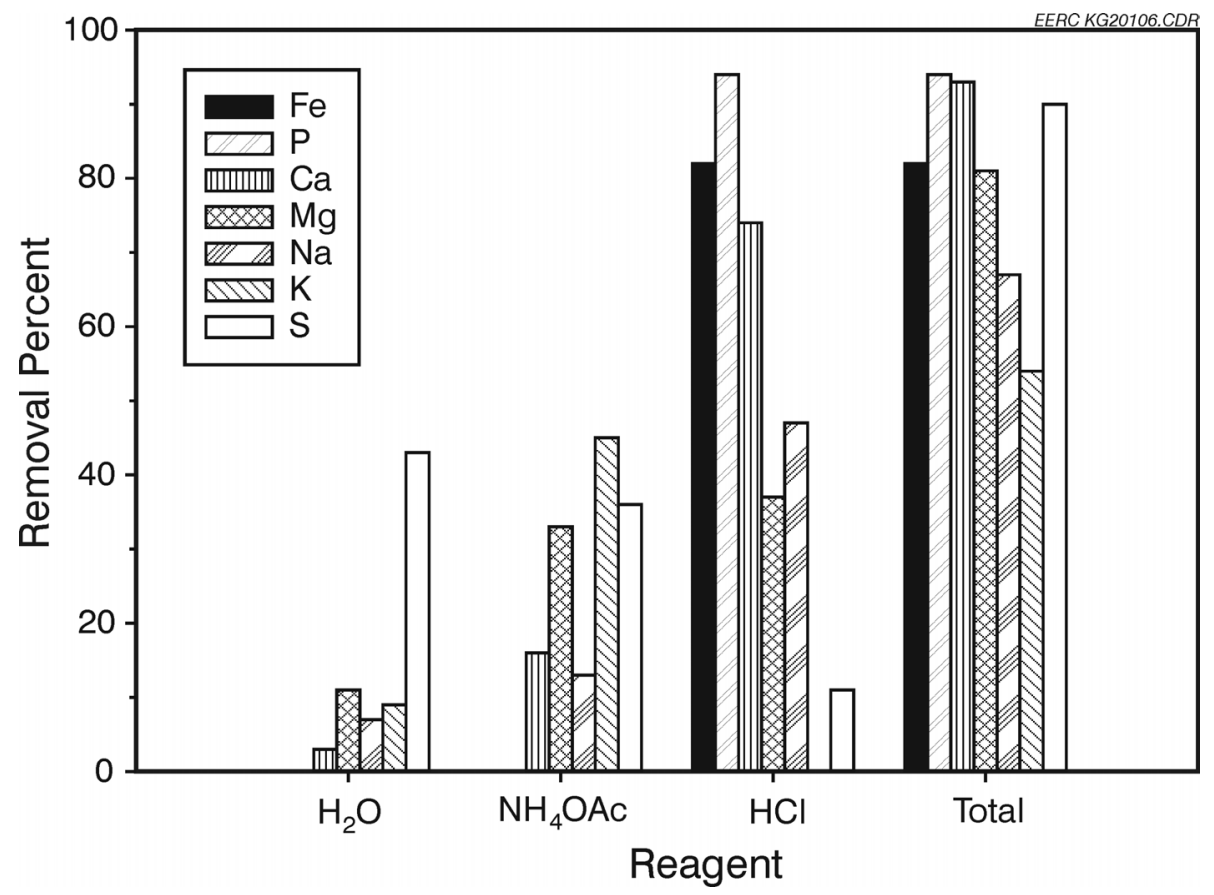

Figure 4. Biosolid chemical fractionation results.

The biosolids contain a high proportion, $>20 \%$ removal, of water-soluble $\mathrm{S}$. The biosolids also contain significant proportions of $\mathrm{NH}_{4} \mathrm{OAc}$-soluble $\mathrm{Mg}, \mathrm{K}$, and $\mathrm{S}$, as well as $\mathrm{HCl}$-soluble Fe-, $\mathrm{P}$-, $\mathrm{Ca}-, \mathrm{Mg}$-, and $\mathrm{Na}$-bearing compounds. The high $\mathrm{HCl}$ removal proportions for $\mathrm{Fe}, \mathrm{P}$, and $\mathrm{Ca}$ suggest that these elements are associated with a phosphate compound.

\subsubsection{Trace Element Analysis Results and Calculated Maximum Emission Factors}

Trace element analysis results for the Colbert coal blend, lignin, and acidified biosolids are presented in Table 14. Trace element concentrations, especially for $\mathrm{Cr}, \mathrm{Pb}, \mathrm{Hg}$, and $\mathrm{Ni}$, are generally much higher in the lignin and acidified biosolids fuels relative to the coal.

The heating values in Table 5 and trace element analysis results from Table 14 were used to calculate maximum trace element emission factors for the Colbert coal blend, lignin, and acidified biosolid fuels. These factors were calculated assuming that the fuel trace elements are completely released to the atmosphere following combustion. Actual trace element emissions from a utilityscale combustion system will be less than those presented in Table 15 because of elemental partitioning among bottom ash, fly ash, and flue gas and elemental capture in pollution control devices (e.g., ESP, baghouse, or wet scrubber).

Calculated maximum trace element emission factors are compared in Table 16 for Colbert coal-lignin and Colbert coal-lignin-acidified biosolid blends and EPA emission factors for pulverized coal-fired units that are unequipped with pollution control devices (9). Calculated 
Table 14. Fuel Trace Element Analysis Results, moisture-free ppm

\begin{tabular}{llcc}
\hline Element & Colbert Coal Blend & Lignin & Biosolids \\
\hline $\mathrm{As}$ & 1.4 & 7.3 & 6.3 \\
$\mathrm{Cd}$ & 0.19 & 2.91 & 2.12 \\
$\mathrm{Cr}$ & 7.83 & 144 & 66.5 \\
$\mathrm{Co}$ & 1.6 & 1.9 & 3.5 \\
$\mathrm{~Pb}$ & 8.2 & 104 & 49.9 \\
$\mathrm{Hg}$ & 0.042 & 1.35 & 2.92 \\
$\mathrm{Ni}$ & 5.86 & 67.1 & 34.0 \\
$\mathrm{Sb}$ & 0.4 & 21 & 2.2 \\
$\mathrm{Se}$ & 1.1 & 0.87 & 6.8 \\
\hline
\end{tabular}

\begin{tabular}{|c|c|c|c|}
\hline Element & Colbert Coal Blend & Lignin & Biosolids \\
\hline As & 120 & 1045 & 1086 \\
\hline $\mathrm{Cd}$ & 16 & 417 & 366 \\
\hline $\mathrm{Cr}$ & 672 & 20616 & 11466 \\
\hline $\mathrm{Co}$ & 137 & 272 & 603 \\
\hline $\mathrm{Pb}$ & 704 & 14889 & 8603 \\
\hline $\mathrm{Hg}$ & 4 & 193 & 503 \\
\hline $\mathrm{Ni}$ & 503 & 9606 & 5862 \\
\hline $\mathrm{Sb}$ & 34 & 3021 & 379 \\
\hline $\mathrm{Se}$ & 94 & 125 & 1172 \\
\hline
\end{tabular}

${ }^{\mathrm{a}}$ To convert from $\mathrm{lb} / 10^{12} \mathrm{Btu}$ to $\mathrm{pg} / \mathrm{J}$, multiply by 0.43 .

Table 16. Comparison of Trace Element Emission Factors, $1 \mathrm{lb} / 10^{12} \mathrm{Btu}^{\mathrm{a}}$

\begin{tabular}{lrrcc}
\hline & \multicolumn{2}{c}{ Colbert Coal-Lignin-Biosolid Blend Ratio } & \multicolumn{2}{c}{ Furnace Type $^{\mathrm{b}}$} \\
\cline { 2 - 5 } Element & $95: 5: 0$ & $90: 5: 5$ & Wet Bottom & Dry Bottom \\
\hline $\mathrm{As}$ & 166 & 215 & 538 & 684 \\
$\mathrm{Cd}$ & 36 & 54 & $44-70$ & 44.4 \\
$\mathrm{Cr}$ & 2209 & $1020-1570$ & $1250-1570$ \\
$\mathrm{Co}$ & 1669 & 167 & $\mathrm{NR}^{\mathrm{c}}$ & $\mathrm{NR}$ \\
$\mathrm{Pb}$ & 1408 & 507 & 507 \\
$\mathrm{Hg}$ & 1413 & 38 & 16 & 16 \\
$\mathrm{Ni}$ & 13 & 1226 & $840-1290$ & 37,051 \\
$\mathrm{Sb}$ & 958 & 201 & $\mathrm{NR}$ & $\mathrm{NR}$ \\
$\mathrm{Se}$ & 183 & 149 & $\mathrm{NR}$ & $\mathrm{NR}$ \\
\hline
\end{tabular}

${ }^{a}$ To convert from $\mathrm{lb} / 10^{12} \mathrm{Btu}$ to $\mathrm{pg} / \mathrm{J}$, multiply by 0.43 .

${ }^{\mathrm{b}}$ Uncontrolled pulverized coal-fired units (10).

${ }^{\mathrm{c}}$ Not reported. 
maximum trace element emission factors for the fuel blends are generally less than or within the range of those for the uncontrolled coal-fired units, except for $\mathrm{Cr}$ and $\mathrm{Pb}$, which are greater.

\subsubsection{Mineralogy}

The fuels were analyzed using CCSEM to size, identify, and quantify the mineral species in Table 17. As indicated in Table 18, quartz, clays (kaolinite, mixed clays, and illite), and carbonate minerals (calcite and dolomite-ankerite) are very abundant in the Colbert coal blend. Pittsburgh No. 8 coal contains primarily quartz, clays, pyrite, and calcite. The lignin is composed primarily of gypsum. The $\mathrm{NH}_{4} \mathrm{OAc}$ extraction of Ca and $\mathrm{S}$ (Figure 3 ) is consistent with the presence of gypsum. The acidified biosolids contain relatively high proportions of gypsum, quartz, and phases classified as "others." Chemical analysis results that do not strictly conform to the compositional ranges of the common coal minerals in Table 17 are assigned to this classification category.

Size distributions are compared in Figure 5 for the inorganic compounds, primarily minerals, composing the four parent fuels. Minerals in the Colbert coal blend are generally larger relative to the Pittsburgh No. 8 coal. The lignin mineral-size distribution is essentially intermediate relative to the two coals. Minerals present in the biosolids are much finer relative to the other fuels.

Table 17. Mineral Classifications and Nominal Chemical Formulas, wt\%

\begin{tabular}{lc} 
Mineral Category & Nominal Chemical Formula \\
\hline Quartz & $\mathrm{SiO}_{2}$ \\
Kaolinite & $\mathrm{Al}_{2} \mathrm{Si}_{2} \mathrm{O}_{5}(\mathrm{OH})_{4}$ \\
Mixed Clays & $\left(\mathrm{Ca}_{0.5}, \mathrm{Na}\right)_{0.33}(\mathrm{Al}, \mathrm{Fe}, \mathrm{Mg})_{2-3}(\mathrm{Al}, \mathrm{Si})_{4} \mathrm{O}_{10}(\mathrm{OH})_{2} \cdot \mathrm{nH}_{2} \mathrm{O}$ \\
Illite & $\mathrm{K}(\mathrm{Al}, \mathrm{Mg}, \mathrm{Fe})_{2}(\mathrm{Si}, \mathrm{Al})_{4} \mathrm{O}_{10} \cdot\left[(\mathrm{OH})_{2}, \mathrm{H}_{2} \mathrm{O}\right]$ \\
Feldspar & $(\mathrm{Ca}, \mathrm{Na}, \mathrm{K})(\mathrm{Al}, \mathrm{Si})_{4} \mathrm{O}_{8}$ \\
Pyrite and Pyrrhotite & $\mathrm{FeS}{ }_{2}$ and Fe ${ }_{1-\mathrm{x}} \mathrm{S}$ \\
Calcite & $\mathrm{CaCO} \mathrm{O}_{3}$ \\
Dolomite-Ankerite & $\mathrm{Ca}(\mathrm{Fe}, \mathrm{Mg})\left(\mathrm{CO}_{3}\right)_{2}$ \\
Hematite & $\mathrm{Fe}_{2} \mathrm{O}_{3}$ \\
Rutile & $\mathrm{TiO}_{2}$ \\
Gypsum & $\mathrm{CaSO} \cdot 2 \mathrm{H}_{2} \mathrm{O}$ \\
Barite & $\mathrm{BaSO}_{4}$ \\
Apatite & $\left(\mathrm{Ca}, \mathrm{K}, \mathrm{Na}_{2} \mathrm{Ba}_{5}\left(\mathrm{PO}_{4}\right)_{3}(\mathrm{Cl}, \mathrm{OH})\right.$ \\
\hline
\end{tabular}


Table 18. Fuel Mineralogical Compositions, wt\%

\begin{tabular}{lcccc}
\hline Fuel: & Colbert Coal Blend & Pittsburgh No. 8 & Lignin & Biosolids \\
\hline Quartz & 21 & 16 & 7.9 & 15 \\
Kaolinite & 11 & 21 & 0.6 & 1.0 \\
Mixed Clays & 12 & 6.7 & 0.6 & 1.9 \\
Illite & 16 & 7.3 & 1.7 & 4.1 \\
Feldspar & 4.6 & 0.5 & 0.2 & 3.8 \\
Pyrite and Pyrrhotite & 0.7 & 32 & 0.1 & 1.5 \\
Calcite & 8.1 & 3.3 & $\mathrm{ND}^{\mathrm{a}}$ & 1.8 \\
Dolomite-Ankerite & 7.4 & 0.1 & $\mathrm{ND}$ & 0.8 \\
Hematite & 0.6 & 0.1 & 0.9 & 1.4 \\
Rutile & 0.2 & 0.3 & 0.2 & 0.7 \\
Gypsum & 0.6 & $\mathrm{ND}$ & 83 & 16 \\
Barite & 0.1 & $\mathrm{ND}$ & 0.2 & $\mathrm{ND}$ \\
Apatite & 1.3 & 0.1 & $\mathrm{ND}$ & 3.2 \\
Unclassified $_{\text {Total }}^{\mathrm{b}}$ & 16 & 12 & 4.3 & 48 \\
\hline
\end{tabular}

${ }^{a}$ Not detected.

${ }^{\mathrm{b}}$ Total does not equal $100 \mathrm{wt} \%$ because of rounding errors.

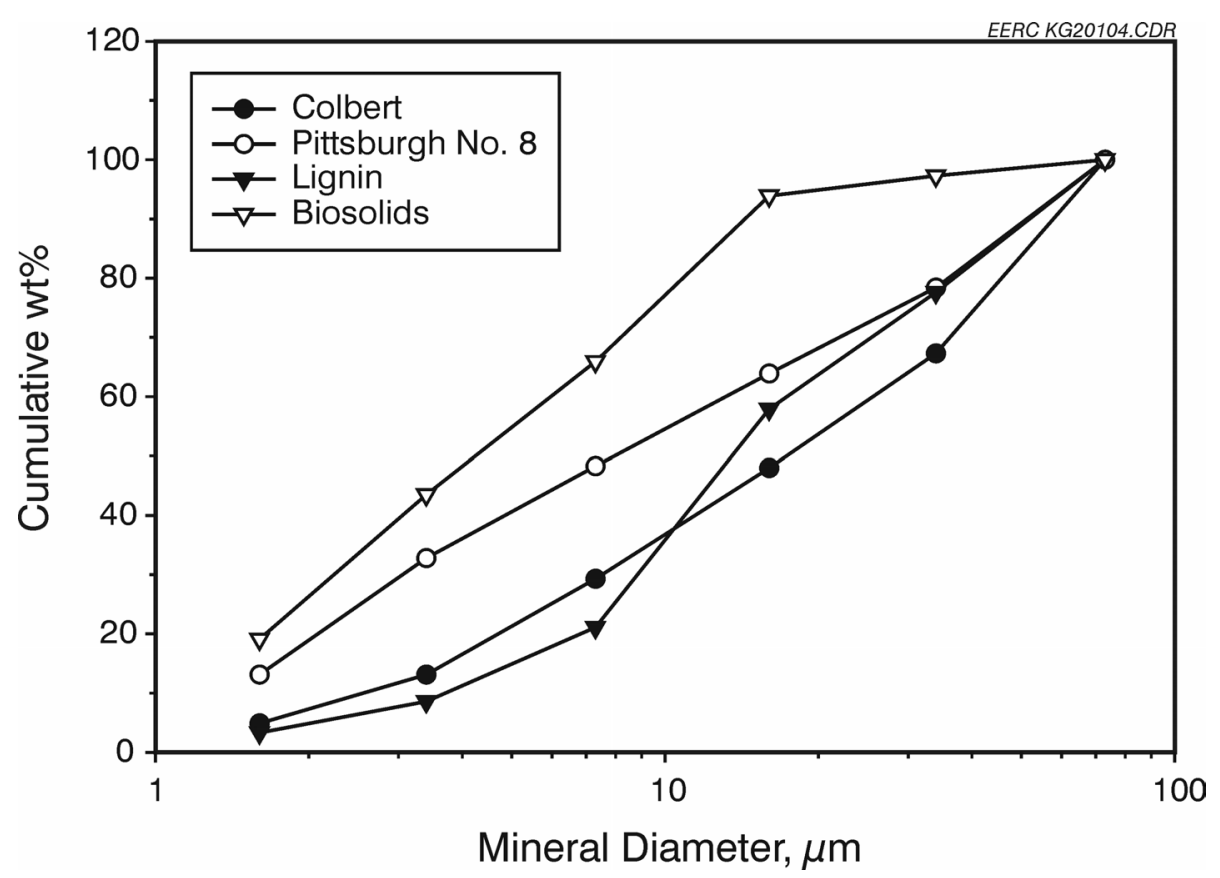

Figure 5. Comparison of mineral-size distributions for the Colbert coal blend, Pittsburgh No. 8, lignin, and biosolid fuels. 


\subsection{Thermal Analysis of Lignin and Acidified Biosolid Fuels}

Differential thermal analysis (DTA) was performed on the lignin and biosolid fuels. DTA involves the measurement of the difference in temperature between a sample and a reference as heat is applied to the system. This method is sensitive to endothermic and exothermic processes, including dehydration and phase transitions and decomposition, redox, or solid-state reactions. The DTA analyses were performed in an inert argon atmosphere. Thermograms for the lignin and acidified biosolid fuels are presented in Figures 6 and 7, respectively. The endothermic peaks, associated with negative temperature differences at about $212^{\circ} \mathrm{F}\left(100^{\circ} \mathrm{C}\right)$, in Figures 6 and 7 correspond to the decomposition of $\mathrm{H}_{2} \mathrm{O}$. The remaining features in Figures 6 and 7, associated with positive temperature differences, are consistent with exothermic processes.

\subsection{Thermochemical Equilibrium Modeling}

The fuel compositions in Tables 5-13 were used as input into the Facility for the Analysis of Chemical Thermodynamics (FACT) to model partial melting, liquid viscosity, and sulfate formation as a function of temperature. FACT is an integrated thermodynamic database coupled to programs developed to calculate multicomponent, multiphase equilibria based on a minimization of Gibbs free energy (10). FACT calculates equilibrium concentrations of solid, liquid, and gas species over a specified temperature range. Calculations were performed at $77^{\circ} \mathrm{F}\left(25^{\circ} \mathrm{C}\right)$ intervals from $932^{\circ} \mathrm{F}$ to $2732^{\circ} \mathrm{F}\left(500^{\circ}\right.$ to $\left.1500^{\circ} \mathrm{C}\right)$. Approximately 30 gas species, a silicate-based slag, a solid calcium-magnesium sulfate solution, and all pure solid species in the FACT database were considered in the calculations. Calculations were performed on a weight basis to determine the proportions of liquid phase as a function of temperature. A second calculation was performed on a mole basis to provide input for viscosity calculations. Viscosities were calculated as a function of temperature using a modified form of the Urbain equation (11).

\subsubsection{Predicted Partial Melting and Liquid Viscosities}

Predicted silicate liquid concentrations as a function of temperature for the parent fuels are presented in Figure 8. The Colbert coal ash is predicted to begin melting at $1697^{\circ} \mathrm{F}\left(925^{\circ} \mathrm{C}\right)$ and produce the most liquid at temperatures typical of a pulverized subbituminous coal-fired boiler, $2372^{\circ} \mathrm{F}\left(\leq 1300^{\circ} \mathrm{C}\right)$. Lignin is predicted to begin melting at $1652^{\circ} \mathrm{F}\left(900^{\circ} \mathrm{C}\right)$ and produce proportions of liquid similar to the Colbert coal. The acidified biosolids are predicted to begin melting at about $2372^{\circ} \mathrm{F}\left(1300^{\circ} \mathrm{C}\right)$ and produce very small, $\leq 10 \mathrm{wt} \%$, amounts of a silicate liquid because of the low $\mathrm{SiO}_{2}$ contents of its ash (Table 11). The partial melting characteristics of Pittsburgh No. 8 coal ash are predicted to be intermediate between those of the Colbert coal, lignin, and biosolid fuels.

Predicted silicate liquid concentrations as a function of temperature for the Colbert parent coal and fuel blends are presented in Figure 9. In general, the blending of lignin with Colbert coal at relatively low levels of $\leq 10 \mathrm{wt} \%$ is predicted to have little effect on ash-melting characteristics. As expected from the parent fuel-melting characteristics (Figure 8), the blending of biosolids with Colbert coal increases the predicted ash-melting temperature by approximately $77^{\circ} \mathrm{F}\left(25^{\circ} \mathrm{C}\right)$ and generally reduces the amount of silicate liquid produced for a given temperature. 


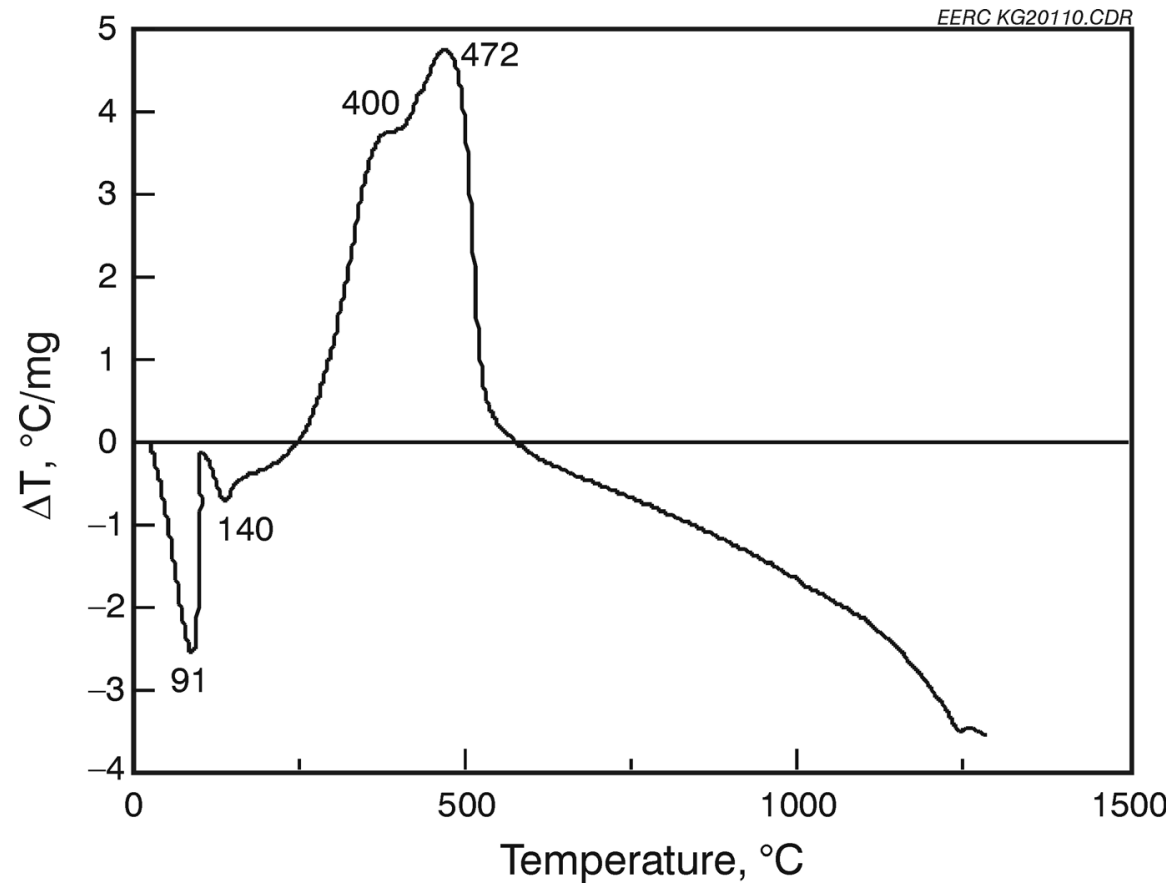

Figure 6. Thermogram for the lignin.

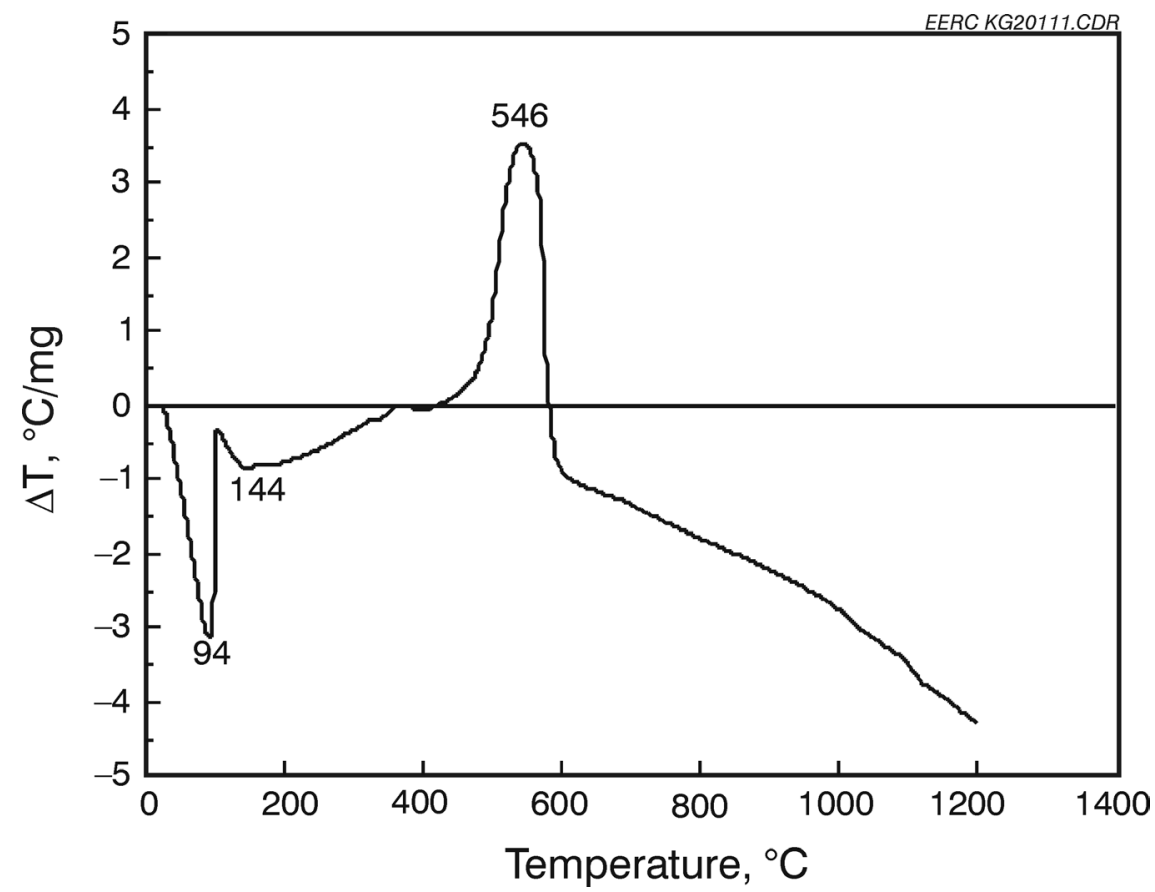

Figure 7. Thermogram for the acidified biosolids. 


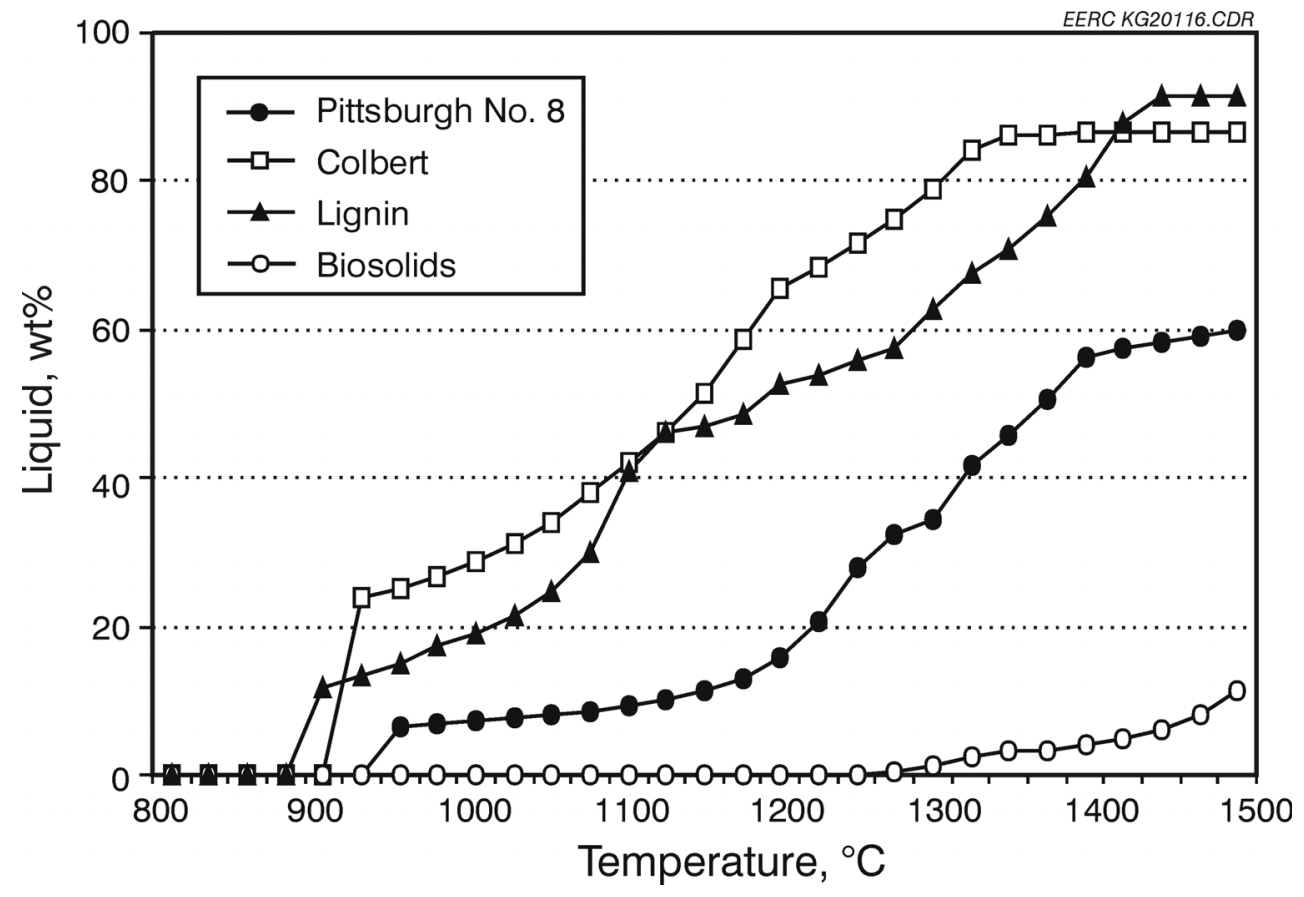

Figure 8. Predicted partial melting characteristics of parent fuel ashes.

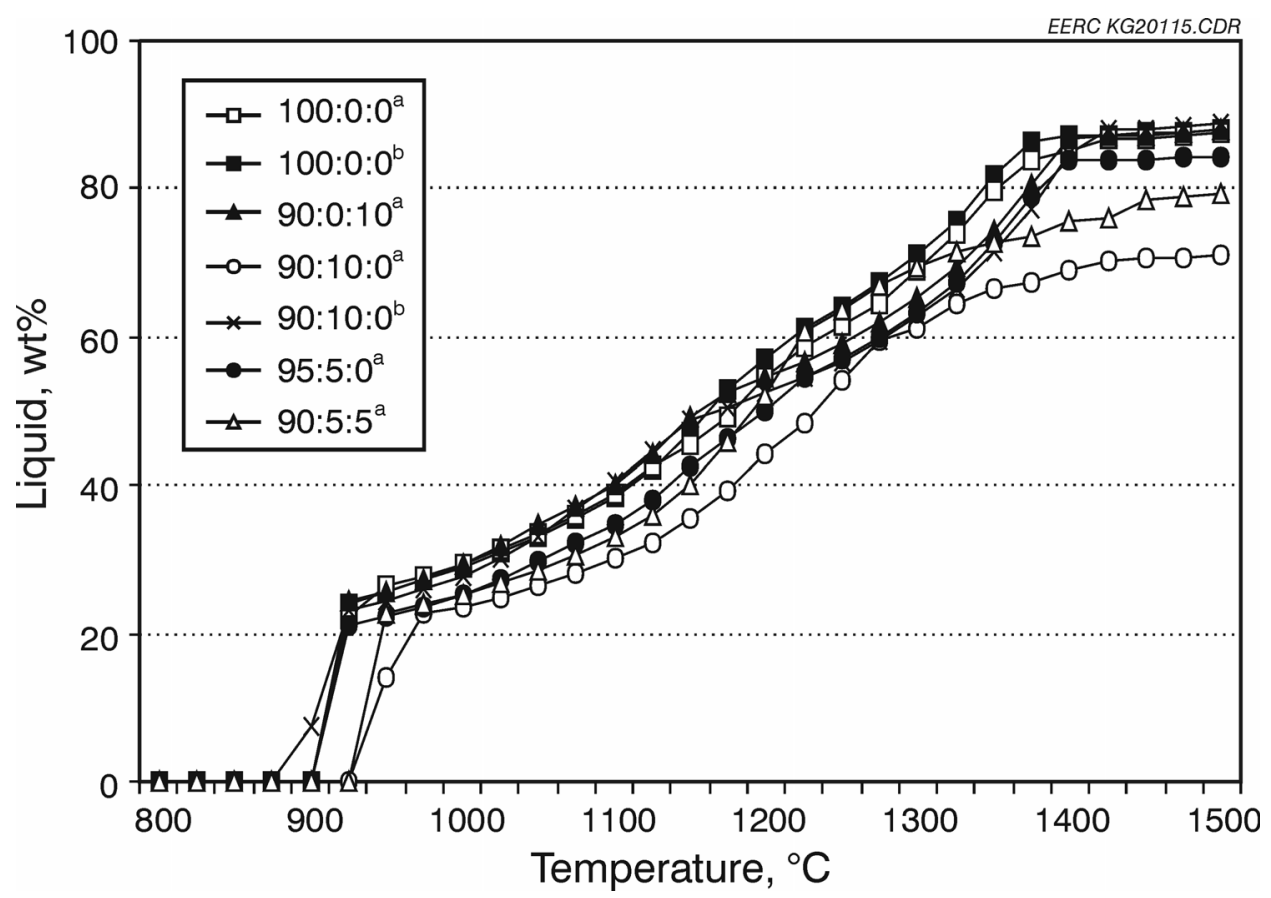

Figure 9. Predicted partial melting characteristics of Colbert parent coal and fuel blend ashes: a) fuel tested at a FEGT of $2200^{\circ} \mathrm{F}\left(1200^{\circ} \mathrm{C}\right)$ and b) fuel tested at an FEGT of $2350^{\circ} \mathrm{F}\left(1290^{\circ} \mathrm{C}\right)$. 
The predicted partial melting characteristics of the Pittsburgh No. 8, lignin and Pittsburgh No. 8-lignin blend are compared in Figure 10. Lignin blending with the Pittsburgh No. 8 coal is predicted to increase the production of silicate liquid by $5-18 \mathrm{wt} \%$ for a given temperature.

Predicted viscosities for liquid phases produced by melting the parent fuel ashes are compared in Figure 11. The lignin and biosolid fuels are predicted to produce lower-viscosity liquids for a given temperature relative to the Colbert and Pittsburgh No. 8 coals. Assuming that these predictions are accurate, the blending of significant proportions of lignin and/or biosolids with the coals should increase slagging and fouling severity.

Comparisons of predicted liquid-phase viscosities for the Colbert parent coal and fuel blends in Figure 12 suggest that the blending of lignin and/or biosolids at relatively low proportions $(\leq 10 \mathrm{wt} \%$, dry basis) does not significantly affect liquid-phase viscosity, especially at $\geq 2330^{\circ} \mathrm{F}\left(\geq 1275^{\circ} \mathrm{C}\right)$. However, the predicted liquid-phase viscosities for the Pittsburgh No. 8 coal and Pittsburgh No. 8 coal-lignin blend, presented in Figure 13, suggest that the blending of $10 \mathrm{wt} \%$ lignin will significantly reduce viscosity at $>2240^{\circ} \mathrm{F}\left(>1225^{\circ} \mathrm{C}\right)$.

\subsubsection{Predicted Effects of Lignin and Biosolid Blending on Ash Sulfation}

The lignin contains uncharacteristically high concentrations of sulfur because it was not thoroughly washed and dried. The biosolids possess sulfur contents intermediate between those of the two parent coals (Table 6). FACT was used to predict the effects of lignin and biosolid blending

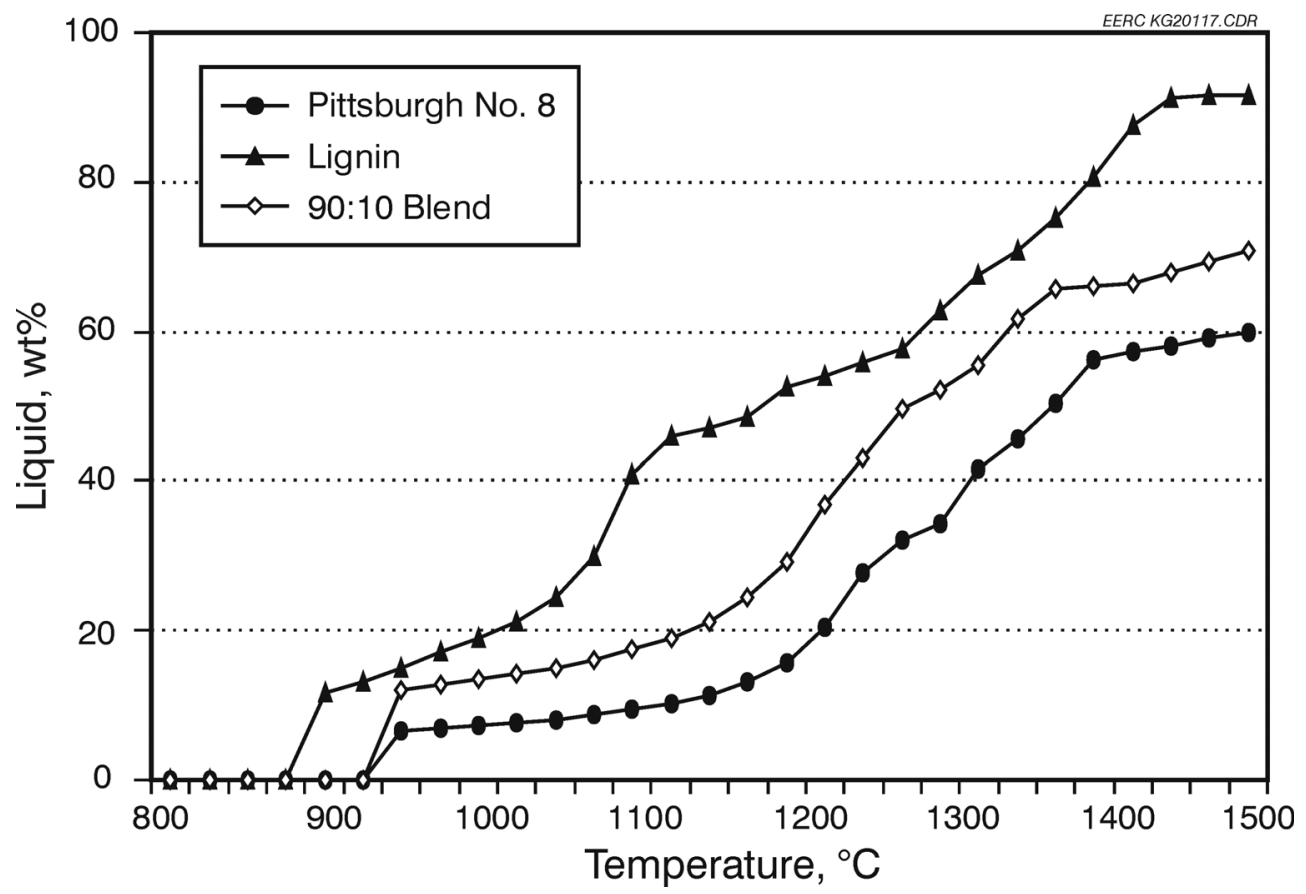

Figure 10. Predicted partial melting characteristics of Pittsburgh No. 8 and Pittsburgh No. 8 coal-lignin blend (90:10) ashes. 


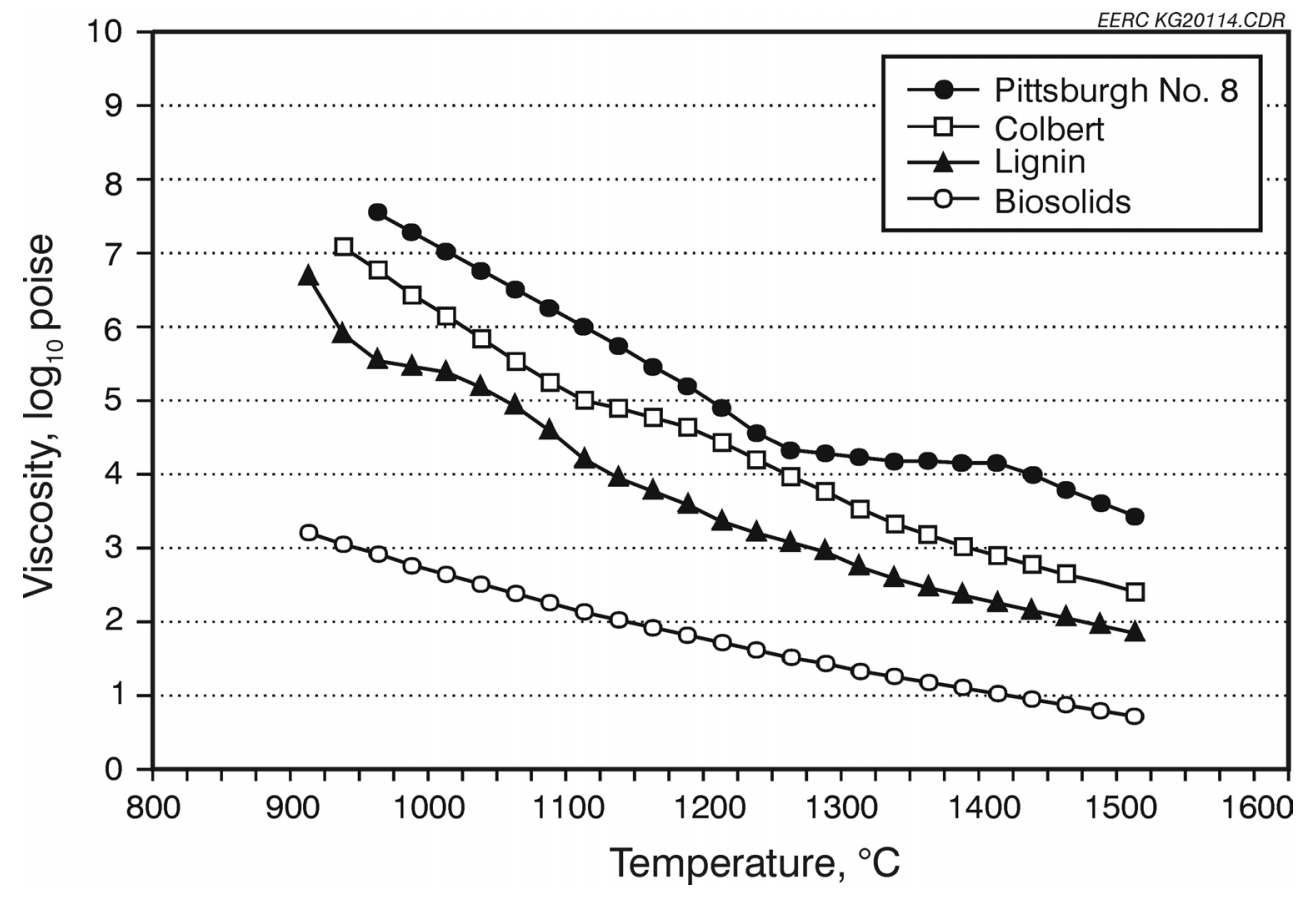

Figure 11. Comparison of predicted slag viscosities for parent fuels.

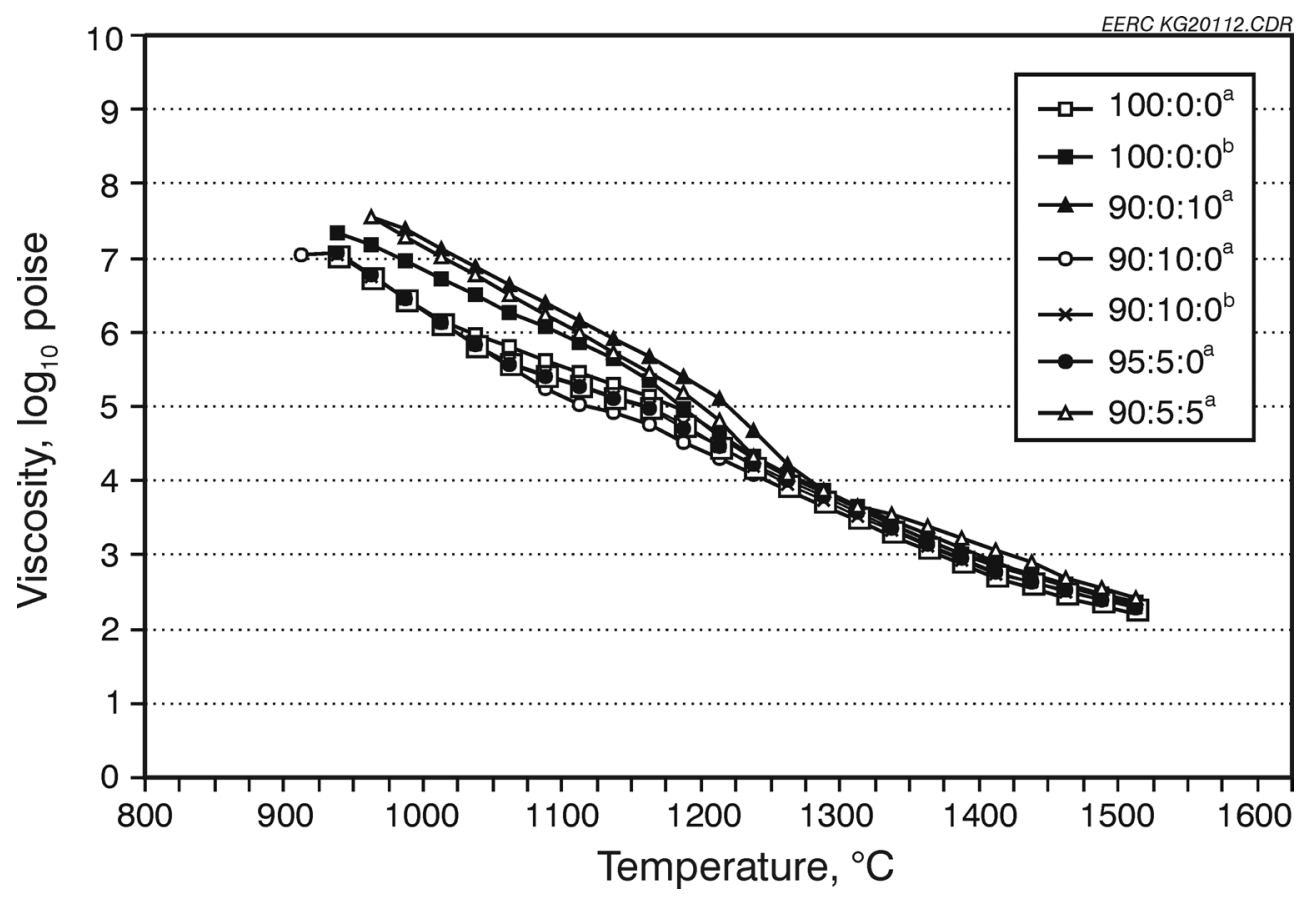

Figure 12. Comparison of predicted slag viscosities for Colbert coal and Colbert coal-lignin-biosolids blends: a) fuel tested at a FEGT of $2200^{\circ} \mathrm{F}\left(1200^{\circ} \mathrm{C}\right)$ and b) fuel tested at a FEGT of $2350^{\circ} \mathrm{F}\left(1290^{\circ} \mathrm{C}\right)$. 


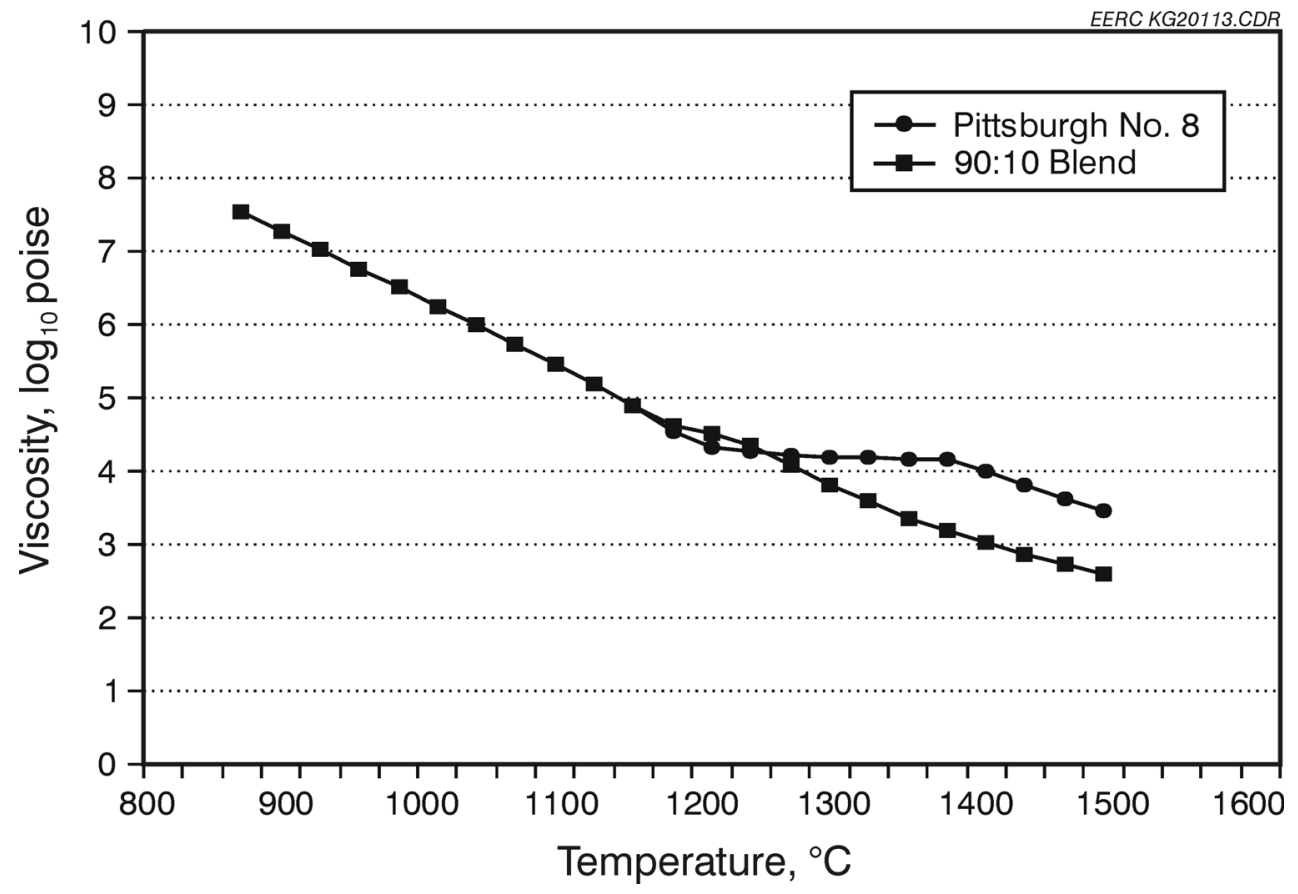

Figure 13. Comparison of predicted slag viscosities for Pittsburgh No. 8 coal and a Pittsburgh No. 8-lignin blend.

and FEGT on the formation of sulfate compounds which generally contribute to low-temperature $\left(<1470^{\circ} \mathrm{F},<800^{\circ} \mathrm{C}\right)$ fouling on convective pass surfaces. Predicted concentrations of sulfate compounds in ashes produced from burning the Colbert coal and its associated fuel blends are presented in Figure 14. The results in Figure 14 suggest that the higher FEGT $\left(2350^{\circ} \mathrm{F}\left[1290^{\circ} \mathrm{C}\right]\right)$ testing of Colbert coal and Colbert coal-lignin (90:10) blend promotes ash sulfation. Results for the Colbert fuels tested at a FEGT of $2200^{\circ} \mathrm{F}\left(1200^{\circ} \mathrm{C}\right)$ suggest that lignin blending at low levels ( $\leq 10 \mathrm{wt} \%$, dry basis) slightly increases ash sulfation by $\leq 5 \mathrm{wt} \%$. Commercially processed lignin is anticipated to have an even lesser effect on ash sulfation because of its lower sulfur content relative to the lignin received for this investigation. Biosolid blending at $\leq 10 \mathrm{wt} \%$ (dry basis) is predicted to have a minimal effect on the degree of ash sulfation; however, it may reduce the initiation temperature of ash sulfation by about $120^{\circ} \mathrm{F}\left(50^{\circ} \mathrm{C}\right)$.

Predicted ash sulfation results for the Pittsburgh No. 8, lignin, and Pittsburgh No. 8 coal-lignin (90:10) blend are presented in Figure 15. As expected from the uncharacteristically high sulfur content of the lignin, it is predicted to contribute to the sulfation of Pittsburgh No. 8 coal ash.

\subsection{Combustion Tests}

\subsubsection{Temperatures}

Combustion system temperatures for the Colbert coal-lignin-biosolid and Pittsburgh No. 8 coal-lignin tests are presented in Tables 19 and 20, respectively. These temperatures are comparable 


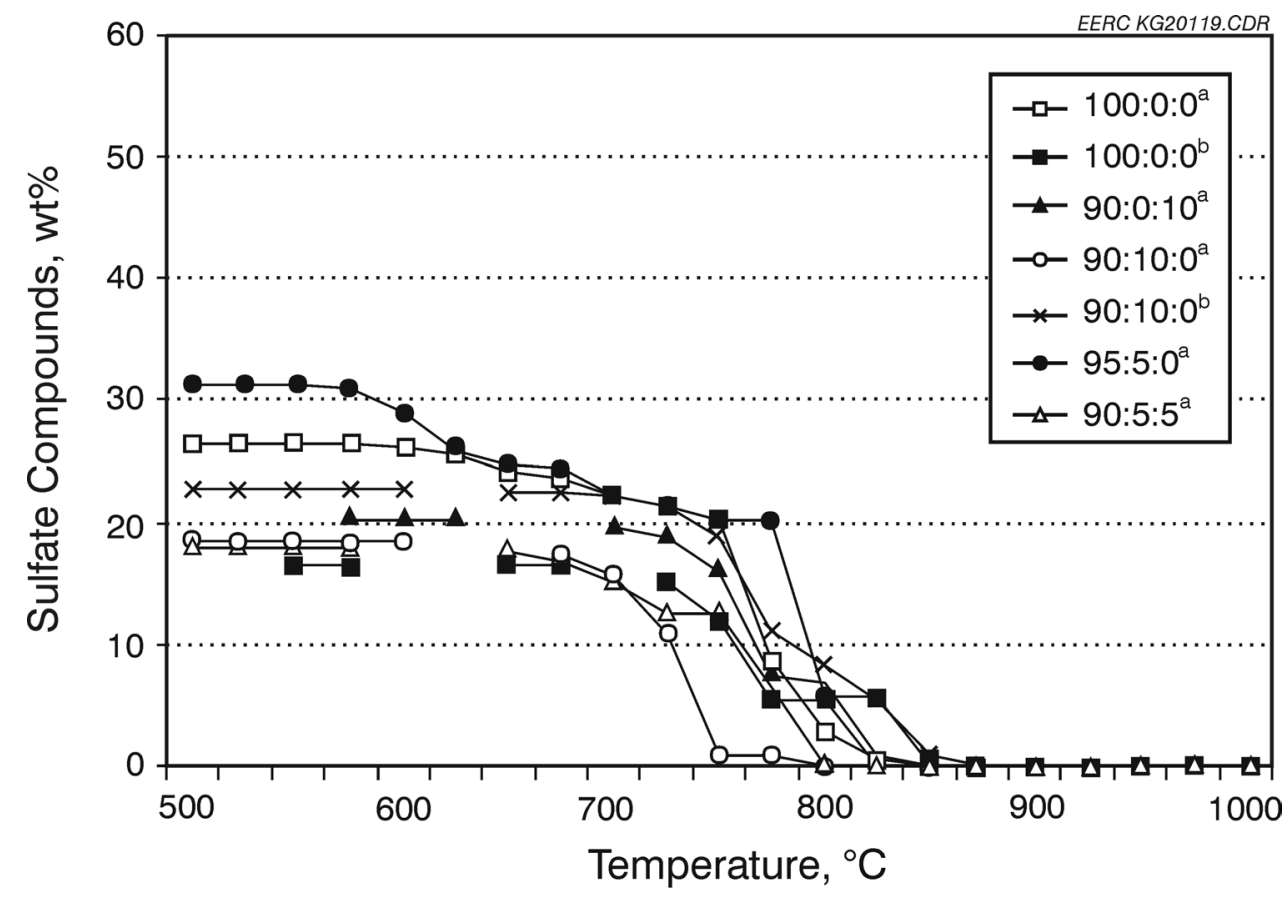

Figure 14. Predicted ash sulfate compound concentration as a function of temperature for the Colbert coal and Colbert coal-lignin-biosolid blends: a) fuel tested at a FEGT of $2200^{\circ} \mathrm{F}\left(1200^{\circ} \mathrm{C}\right)$ and $\left.\mathrm{b}\right)$ fuel tested at a FEGT of $2350^{\circ} \mathrm{F}\left(1290^{\circ} \mathrm{C}\right)$.

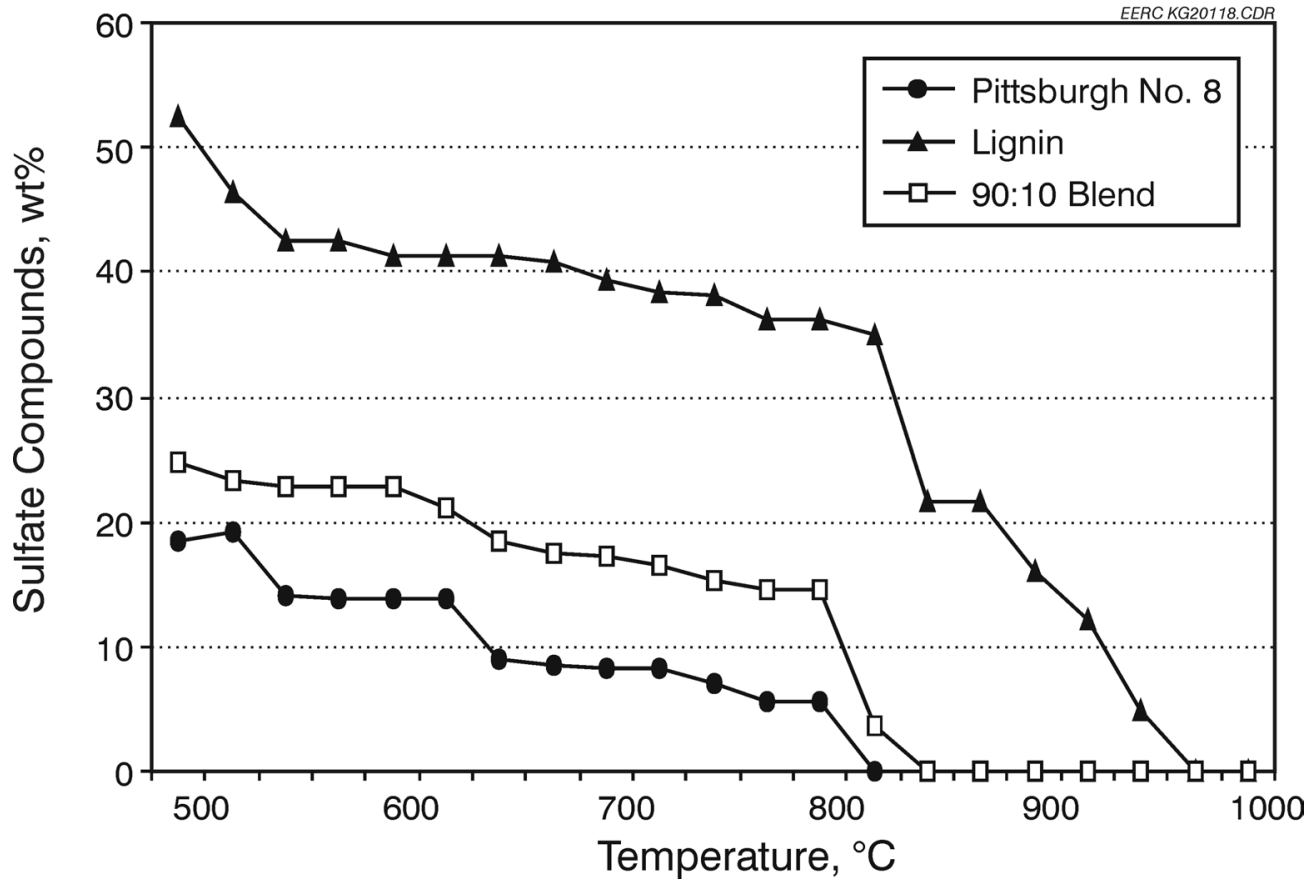

Figure 15. Predicted ash sulfate compound concentration as a function of temperature for the Pittsburgh No. 8 coal, lignin, and Pittsburgh No. 8 coal-lignin (90:10) blend. 
Table 19. Colbert Coal-Lignin-Biosolid Combustion System Temperatures, ${ }^{\circ} \mathrm{F}\left({ }^{\circ} \mathrm{C}\right)$

\begin{tabular}{lccccccc}
\hline & \multicolumn{7}{c}{ Colbert Coal-Lignin-Biosolid Blend Ratio } \\
\cline { 2 - 7 } & $100: 0: 0$ & $100: 0: 0$ & $95: 5: 0$ & $90: 10: 0$ & $90: 10: 0$ & $90: 5: 5$ & $90: 0: 10$ \\
\hline FD Fan & & & & & & & \\
Outlet & $133(56)$ & $132(56)$ & $128(53)$ & $125(52)$ & $128(53)$ & $133(56)$ & $129(54)$ \\
Primary & & & & & & \\
$\quad$ Air & 457 & $337(169)$ & $432(222)$ & $454(234)$ & $148(64)$ & $430(221)$ & $374(190)$ \\
Secondary & & & & & & \\
$\quad$ Air & $573(300)$ & $400(204)$ & $535(279)$ & $574(301)$ & $424(218)$ & $534(279)$ & $423(217)$ \\
Probe Bank & & & & & & \\
$\quad$ Exit & $1732(944)$ & 2144 & $1738(948)$ & $1729(943)$ & 1890 & 1719 & 1754 \\
Probe Bank & & & & & 1000 & \\
$\quad$ Metal & $1015(546)$ & $1010(543)$ & $1005(541)$ & $1005(541)$ & $1005(541)$ & $(538)$ & $1010(543)$ \\
FEGT & 2200 & 2350 & 2220 & 2210 & 2340 & 2200 & 2200 \\
ESP Inlet & $269(132)$ & $344(174)$ & $305(151)$ & $289(143)$ & $326(164)$ & $321(161)$ & $318(159)$ \\
ESP Outlet & $243(117)$ & $308(154)$ & $263(128)$ & $257(125)$ & $288(142)$ & $283(139)$ & $274(135)$ \\
Stack & $137(58)$ & $153(67)$ & $137(58)$ & $131(55)$ & $183(84)$ & $235(113)$ & $146(63)$ \\
\hline
\end{tabular}

${ }^{\mathrm{T}}$ Forced draft.

Table 20. Pittsburgh No. 8 Coal-Lignin Combustion System Temperatures, ${ }^{\circ} \mathrm{F}\left({ }^{\circ} \mathrm{C}\right)$

\begin{tabular}{lcc}
\hline & \multicolumn{2}{c}{ Pittsburgh No. 8 Coal-Lignin Blend Ratio } \\
\cline { 2 - 3 } & $100: 0$ & $90: 10$ \\
\hline FD Fan Outlet & $130(55)$ & $130(55)$ \\
Primary Air & $127(53)$ & $348(175)$ \\
Secondary Air & $429(221)$ & $401(205)$ \\
Probe Bank Exit & $1965(1074)$ & $2065(1129)$ \\
Probe Bank Metal & $1010(543)$ & $1005(541)$ \\
FEGT & $2350(1290)$ & $2350(1290)$ \\
ESP Inlet & $337(170)$ & $327(164)$ \\
ESP Outlet & $293(145)$ & $291(144)$ \\
Stack & $235(113)$ & $150(66)$ \\
\hline
\end{tabular}

to those for utility-scale pulverized coal-fired boilers burning a PRB subbituminous coal (Table 19) and eastern bituminous coal (Table 20).

\subsubsection{Ash Partitioning and Deposition Rates}

Ash recovery results for the Colbert coal-lignin-biosolid and Pittsburgh No. 8 coal-lignin tests are presented in Tables 21 and 22, respectively. Included in Tables 21 and 22 is an indication, in parentheses, whether the fuel fouling potential is low, medium, or high, based on deposit weight and the ranking scheme presented in Table 2. The Colbert coal has a medium fouling potential in 
Table 21. Ash Recoveries for Colbert Coal-Lignin-Biosolid Tests

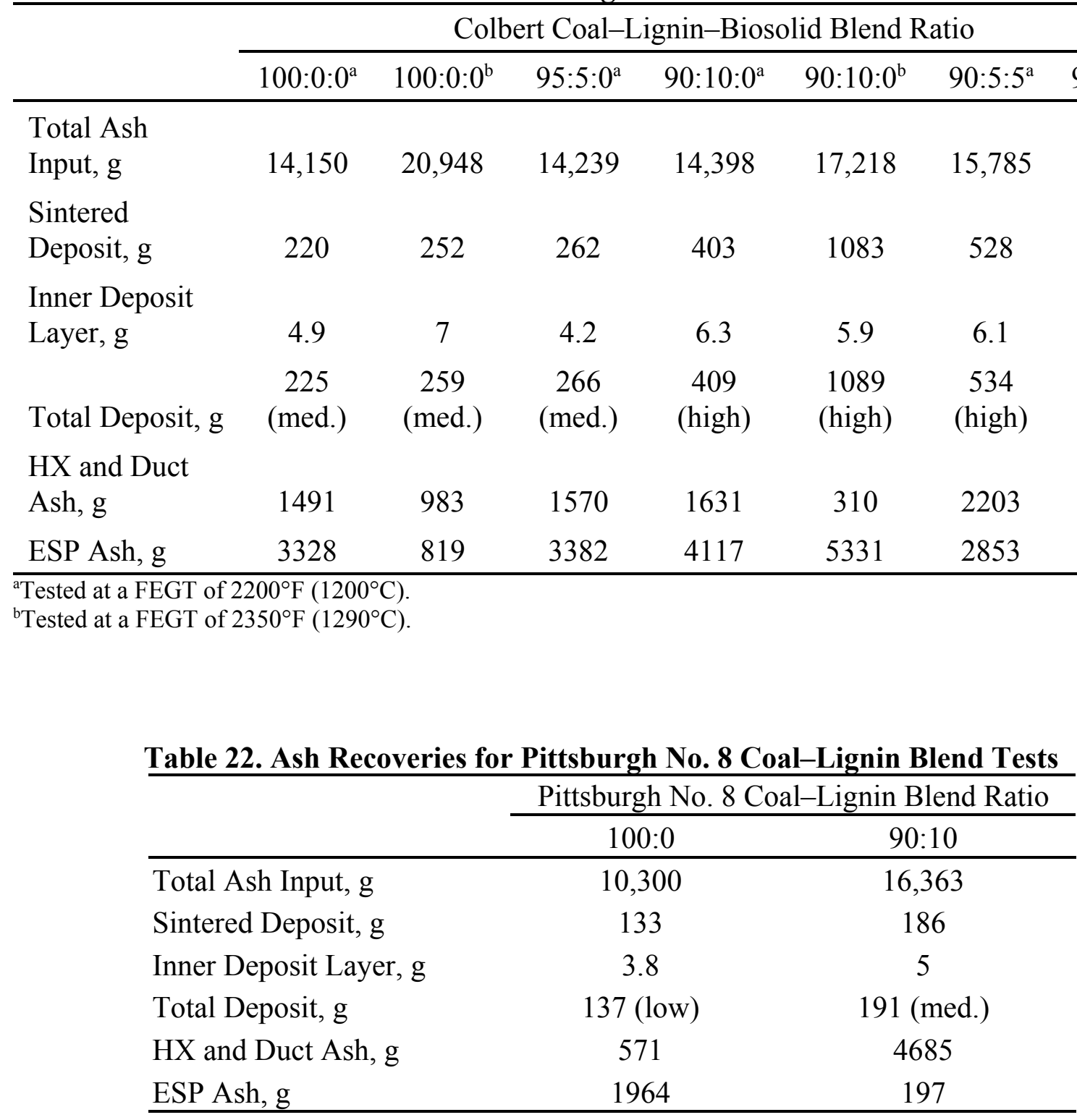

the CTF at both FEGTs tested. The fouling potential of the Colbert coal remained medium at the low lignin blend level of 5 dry wt $\%$. Increasing the lignin blend level to $10 \mathrm{dry} w \mathrm{t} \%$, however, resulted in a high fouling potential. The combination of a relatively high FEGT of $2350^{\circ} \mathrm{F}\left(1290^{\circ} \mathrm{C}\right)$, representative of operational upsets in the TVA Colbert Steam Plant, and a $10 \mathrm{dry} \mathrm{wt} \%$ lignin blend level resulted in the most ash deposition. The blending of acidified biosolids to the Colbert coal also resulted in a high fouling potential. The Pittsburgh No. 8 coal went from low fouling potential to medium as a result of adding 10 dry wt $\%$ lignin.

The total amounts of fuel ash input into the CTF and ash entrained in the flue gas (i.e., summation of deposit, HX, duct, and ESP ash weights) during each test were used in mass balance 


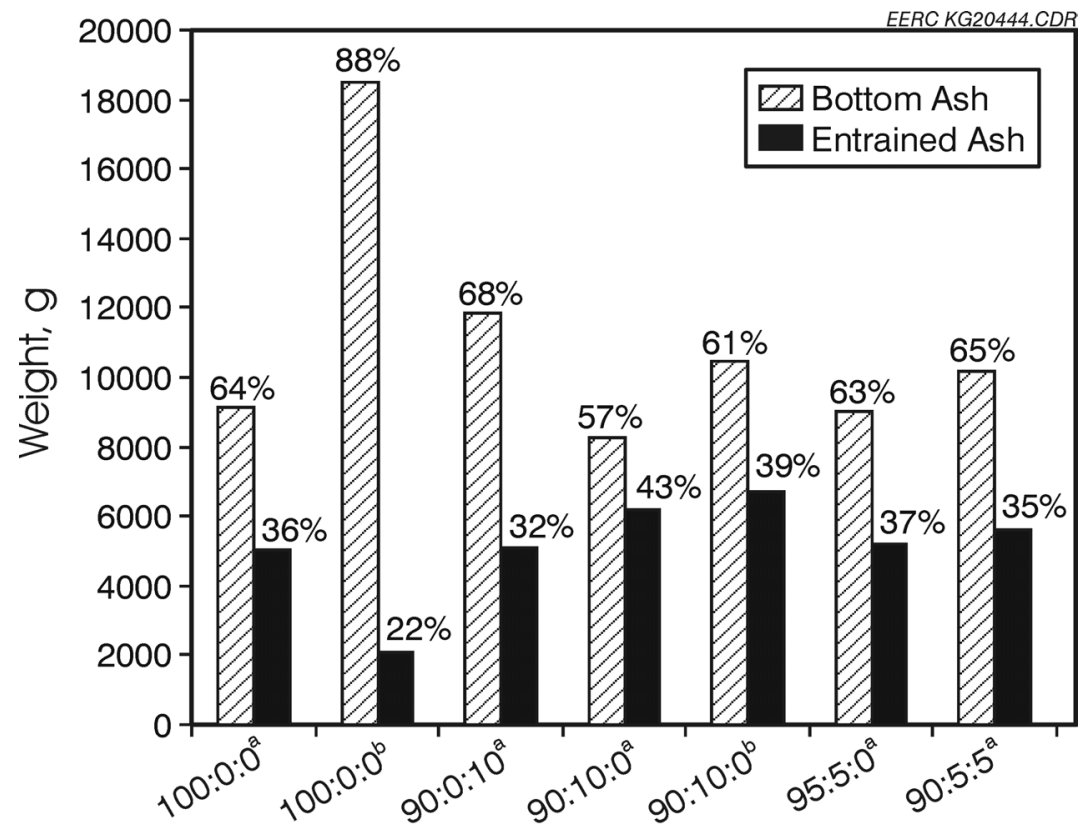

Colbert coal-Lignin-Biosolid Blend Ratio

Figure 16. Bottom ash/entrained ash partitioning for Colbert coal-lignin-biosolid combustion tests: a) tested at a FEGT of $2200^{\circ} \mathrm{F}\left(1200^{\circ} \mathrm{C}\right)$ and b) tested at a FEGT of $2350^{\circ} \mathrm{F}\left(1290^{\circ} \mathrm{C}\right)$.

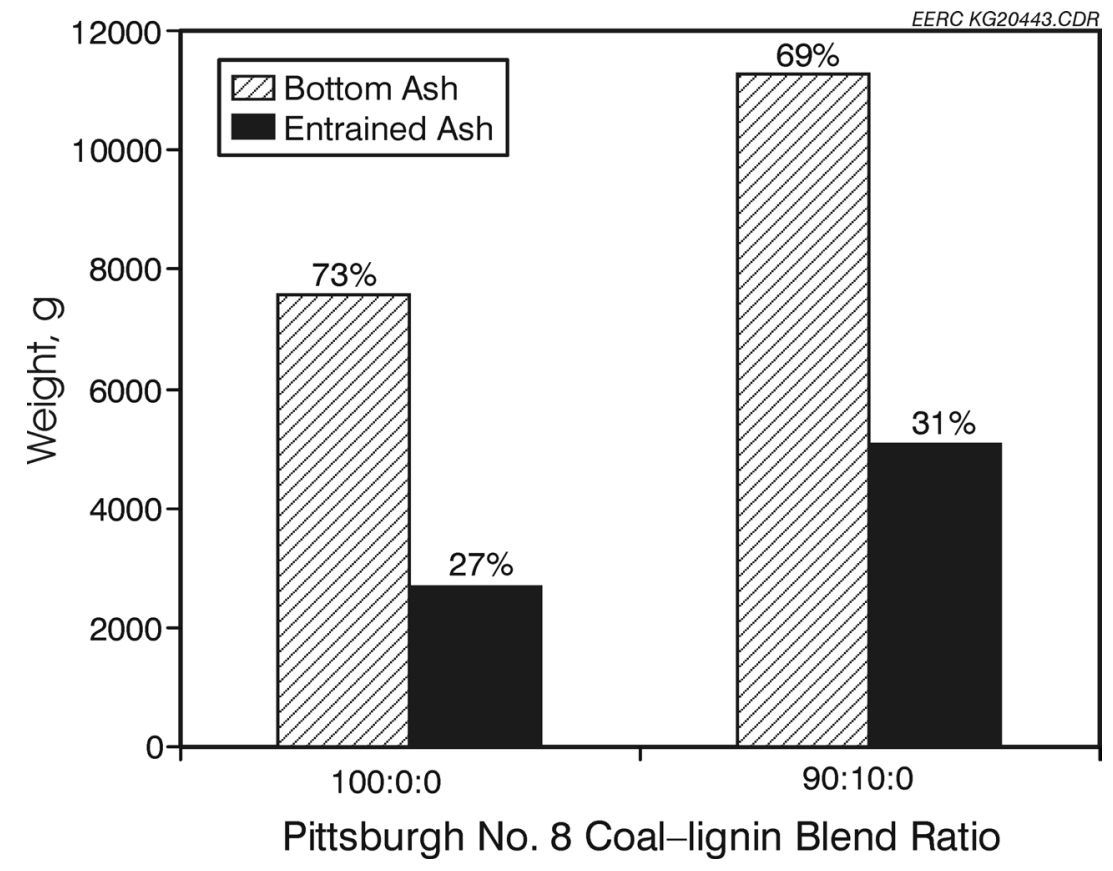

Figure 17. Bottom ash/entrained ash partitioning for Pittsburgh No. 8 coal-lignin combustion tests. 
calculations to estimate bottom ash/entrained ash partitioning. Presented in Figures 16 and 17 are ash-partitioning results for the Colbert coal-lignin-biosolid and Pittsburgh No. 8-lignin combustion tests, respectively. The relative proportions ( $\mathrm{wt} \%$ ) of bottom ash and entrained ash appear above the appropriate bars in Figures 16 and 17. Bottom ash-entrained ash partitioning was similar at about $60 \mathrm{wt} \%-40 \mathrm{wt} \%$ during the Colbert coal and Colbert-lignin-biosolid blend combustion tests except for the baseline Colbert coal test (100:0:0) conducted at the higher FEGT of $2350^{\circ} \mathrm{F}\left(1290^{\circ} \mathrm{C}\right)$. The higher FEGT resulted in a much greater proportion, $\approx 90 \mathrm{wt} \%$, of ash partitioning to the bottom ash. This is consistent with the predicted partial melting characteristics of Colbert coal ash in Figure 8. Bottom ash-entrained ash partitioning was similar at about $70 \%-30 \%$ during the Pittsburgh No. 8 coal and Pittsburgh No. 8 coal-lignin blend combustion tests (Figure 17).

The ash mass balance results in Tables 21 and 22 were also used to calculate ash deposition rates (ash deposition rate $=$ deposit, $\mathrm{g} /$ total ash input, $\mathrm{kg}$ ). Measured ash deposition rates for the Colbert coal and Colbert coal-lignin-biosolid blends are compared in Figure 18. The rates are lowest for the baseline (100:0:0) Colbert coal tests and highest for the 90:10 Colbert coal-lignin blend tested at the higher FEGT of $2350^{\circ} \mathrm{F}\left(1290^{\circ} \mathrm{C}\right)$. The combination of lignin blending and relatively high FEGT enhanced the rate of ash deposition by about $410 \%$. Lignin cofiring at the FEGT of $2200^{\circ} \mathrm{F}\left(1200^{\circ} \mathrm{C}\right)$ and blend levels of 5 and 10 dry wt $\%$ increased the ash deposition rate relative to the baseline Colbert coal by $18 \%$ and $79 \%$, respectively. Deposition rates for the acidified biosolid cofire tests are $34 \%$ and $128 \%$ greater than those resulting from lignin cofiring alone at the lower FEGT of $2200^{\circ} \mathrm{F}\left(1200^{\circ} \mathrm{C}\right)$. The acidified biosolids enhanced the rate of ash deposition more so than lignin. As indicated in Figure 19, the cofiring of lignin with Pittsburgh No. 8 coal had little effect on the ash deposition rate.

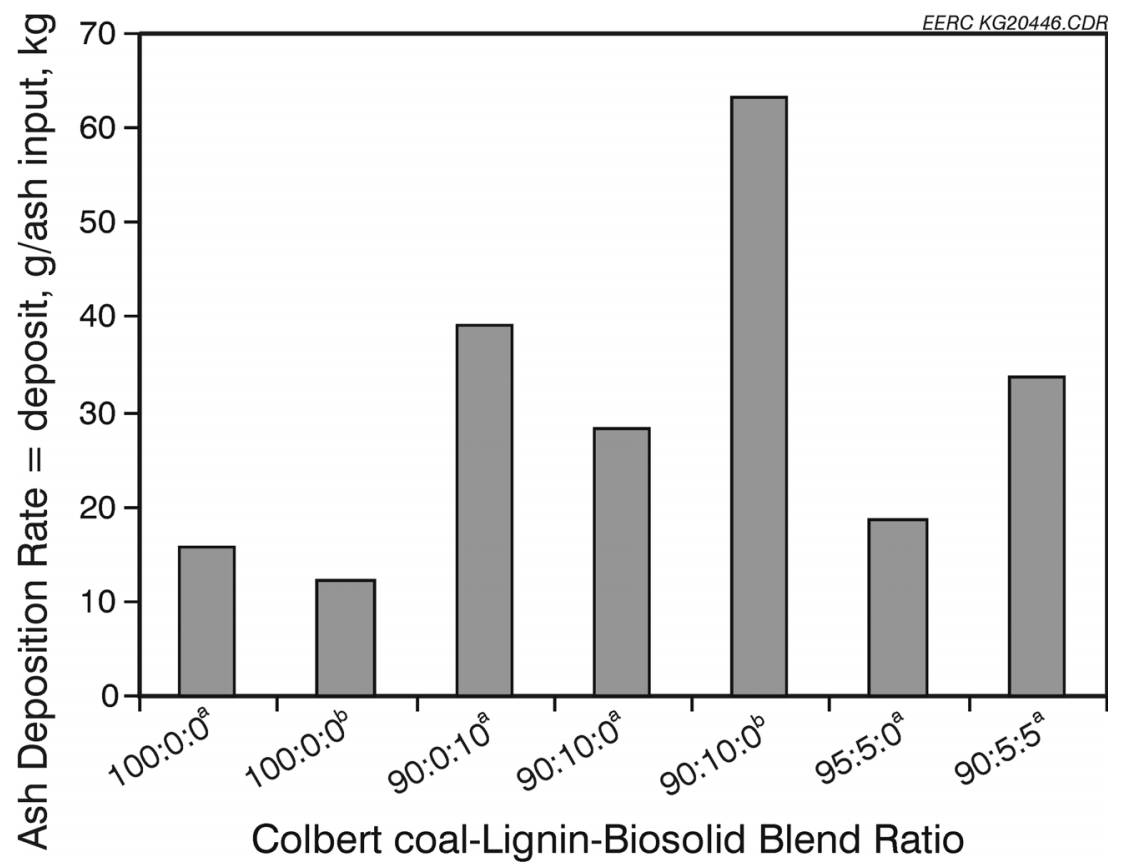

Figure 18. Ash deposition rates for the Colbert coal-lignin-biosolid tests: a) tested at a FEGT of $2200^{\circ} \mathrm{F}\left(1200^{\circ} \mathrm{C}\right)$ and b) tested at a FEGT if $2350^{\circ} \mathrm{F}\left(1290^{\circ} \mathrm{C}\right)$. 


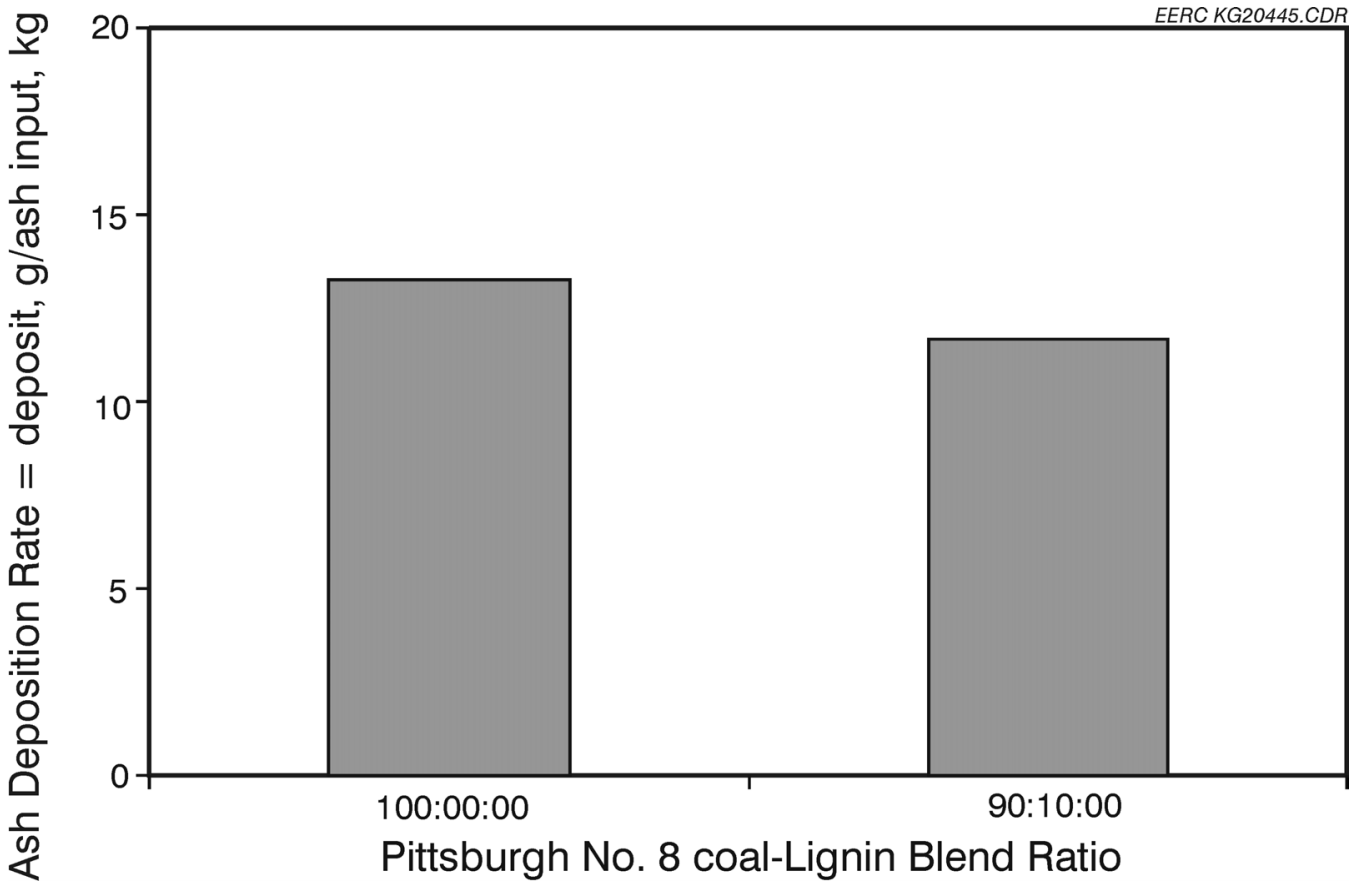

Figure 19. Ash deposition rates for the Pittsburgh No. 8 coal-lignin tests.

\subsubsection{Deposit Morphology and Hardness}

Photographs for the deposits produced by burning Colbert coal and Colbert coal-lignin-biosolid blends are presented in Figures 20-25. Deposits produced from burning 100:0:0, 95:5:0, 90:10:0, and 90:5:5 Colbert coal-lignin-biosolid fuels (Figures 20, 21, 22, and 24, respectively) at a FEGT of $2200^{\circ} \mathrm{F}\left(1200^{\circ} \mathrm{C}\right)$ were friable and, therefore, easily removed from the deposition probes. These deposits were weakly bonded to the deposition probes, and most fell off simply by opening the probe door.

Deposits produced during the combustion of a 90:10 Colbert coal-lignin blend (at the higher FEGT of $2350^{\circ} \mathrm{F}\left[1290^{\circ} \mathrm{C}\right]$ ) and 90:10 Colbert coal-biosolid blend (Figures 23 and 25) were more tenacious and thus more difficult to remove from the deposition probes.

A photograph of deposits produced from burning the Pittsburgh No. 8 coal is shown in Figure 26. Deposits produced from burning a 90:10 Pittsburgh No. 8-lignin blend were indistinguishable from those shown in Figure 26. Deposits produced from the Pittsburgh No. 8 and 90:10 Pittsburgh No. 8-lignin blend were harder than those produced from the Colbert coal and Colbert coal-lignin blends (at a FEGT of $2200^{\circ} \mathrm{F}\left[1200^{\circ} \mathrm{C}\right]$ ).

\subsubsection{Deposit Chemical and Mineralogical Compositions}

The compositions of deposits produced from burning Colbert coal and Colbert coal-lignin-biosolid blends are compared in Table 23. The cofiring of lignin with the Colbert coal 


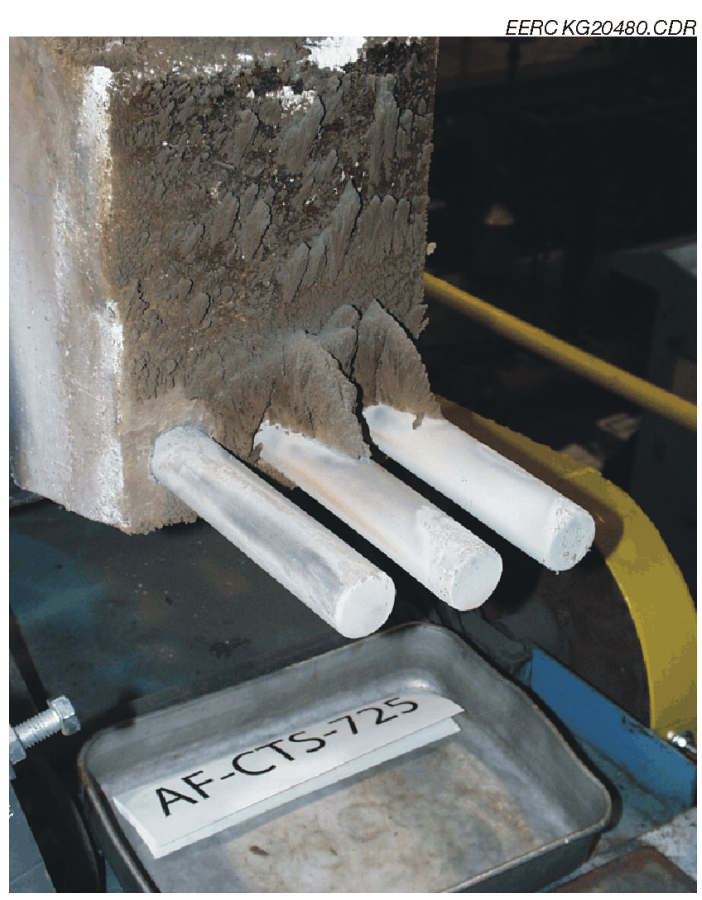

Figure 20. Photograph of the deposit produced by burning Colbert coal at a FEGT of $2200^{\circ} \mathrm{F}\left(1200^{\circ} \mathrm{C}\right)$.

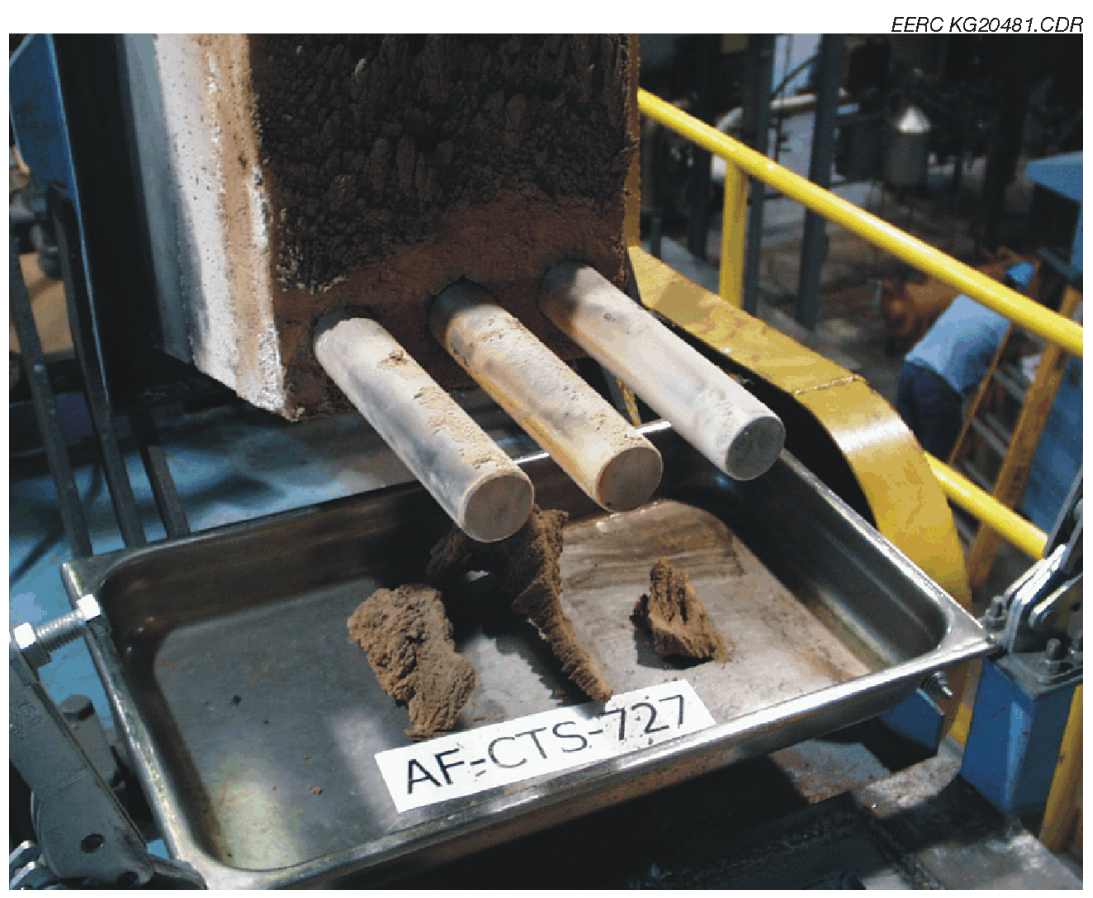

Figure 21. Photograph of the deposit produced by burning Colbert coal-lignin (95:5) blend at a FEGT of $2200^{\circ} \mathrm{F}\left(1200^{\circ} \mathrm{C}\right)$. 


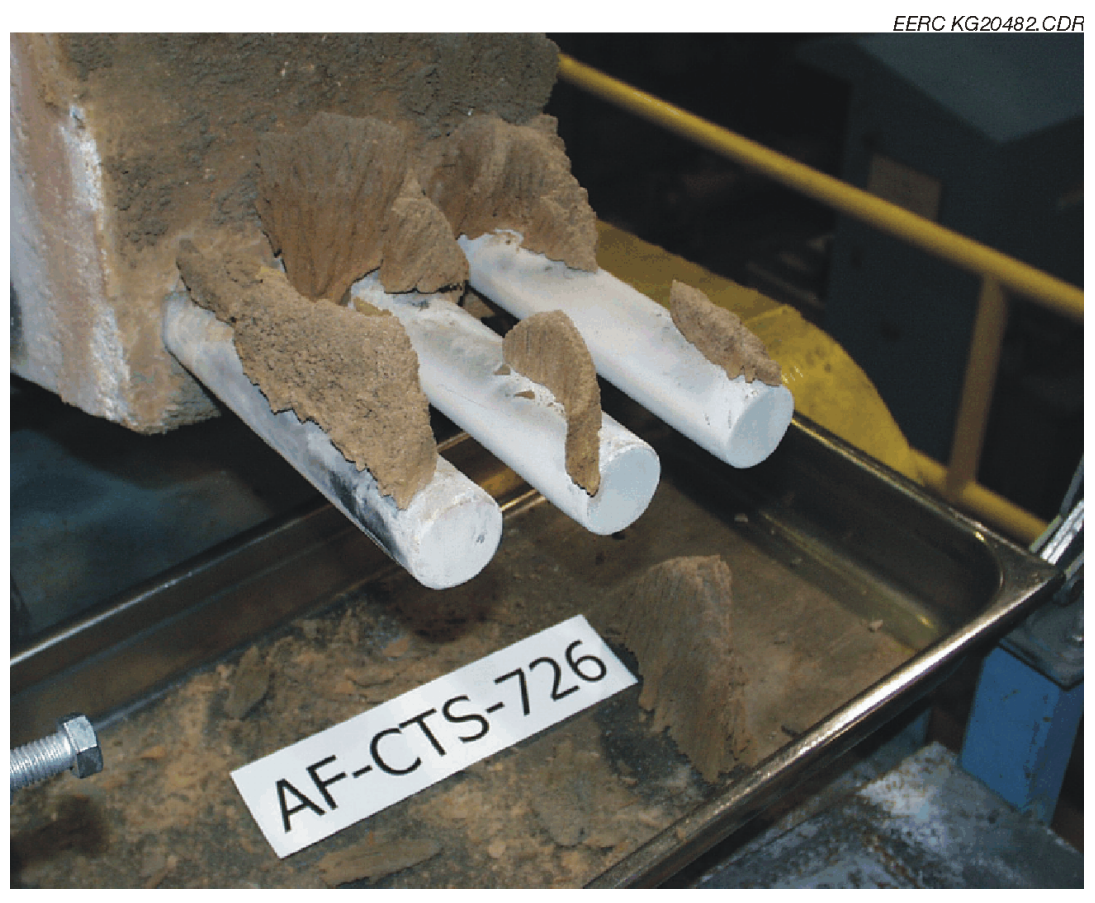

Figure 22. Photograph of the deposit produced by burning a Colbert coal-lignin $(90: 10)$ blend at a FEGT of $2200^{\circ} \mathrm{F}\left(1200^{\circ} \mathrm{C}\right)$.

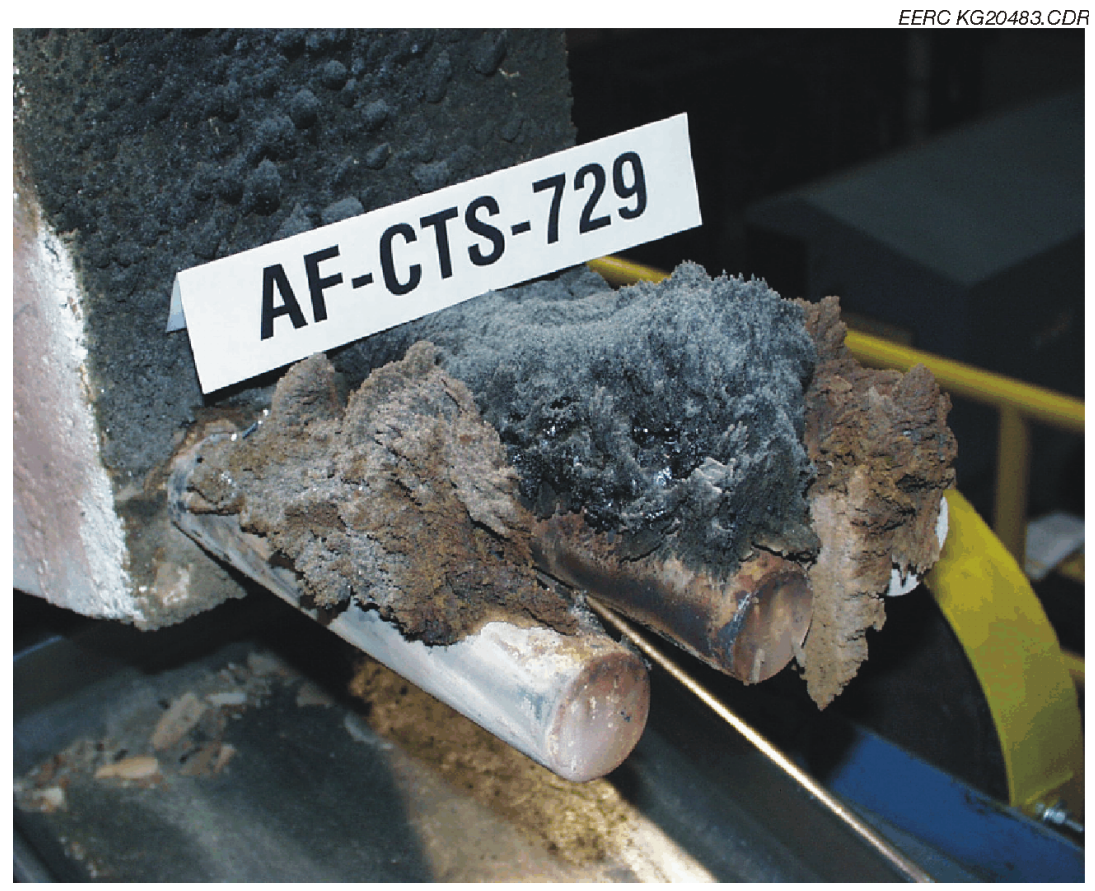

Figure 23. Photograph of the deposit produced by burning Colbert coal-lignin (90:10) blend at a FEGT of $2350^{\circ} \mathrm{F}\left(1290^{\circ} \mathrm{C}\right)$. 


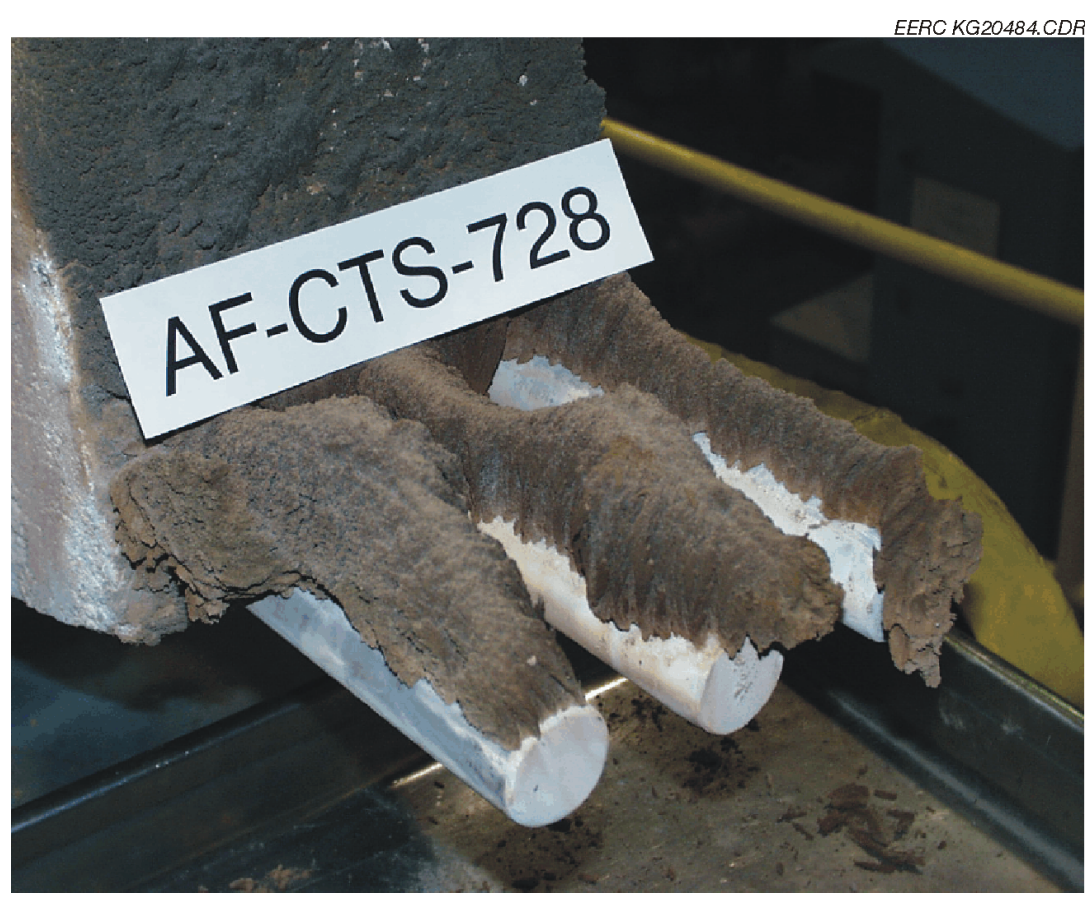

Figure 24. Photograph of the deposit produced by burning a Colbert coal-lignin-biosolid (90:5:5) blend at a FEGT of $2200^{\circ} \mathrm{F}\left(1200^{\circ} \mathrm{C}\right)$.

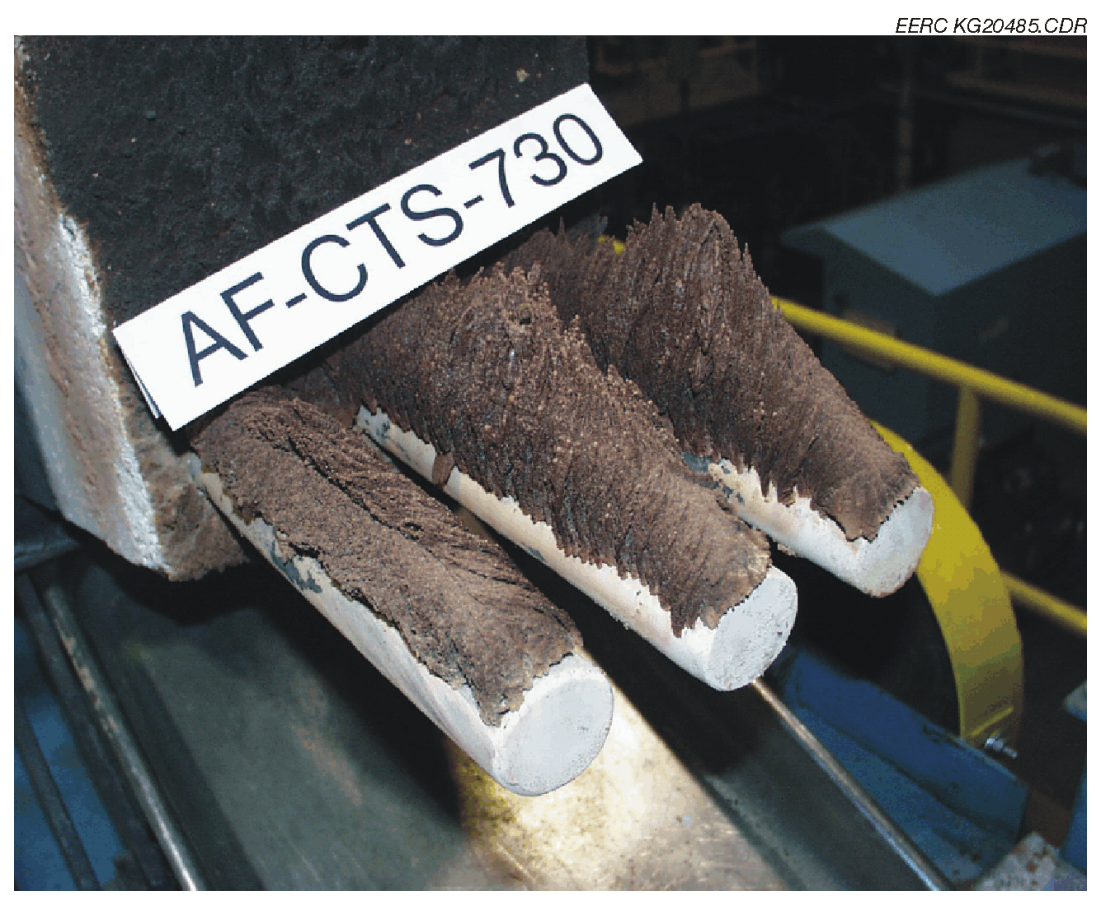

Figure 25. Photograph of the deposit produced by burning a Colbert coal-biosolid $(90: 10)$ blend at a FEGT of $2200^{\circ} \mathrm{F}\left(1200^{\circ} \mathrm{C}\right)$. 


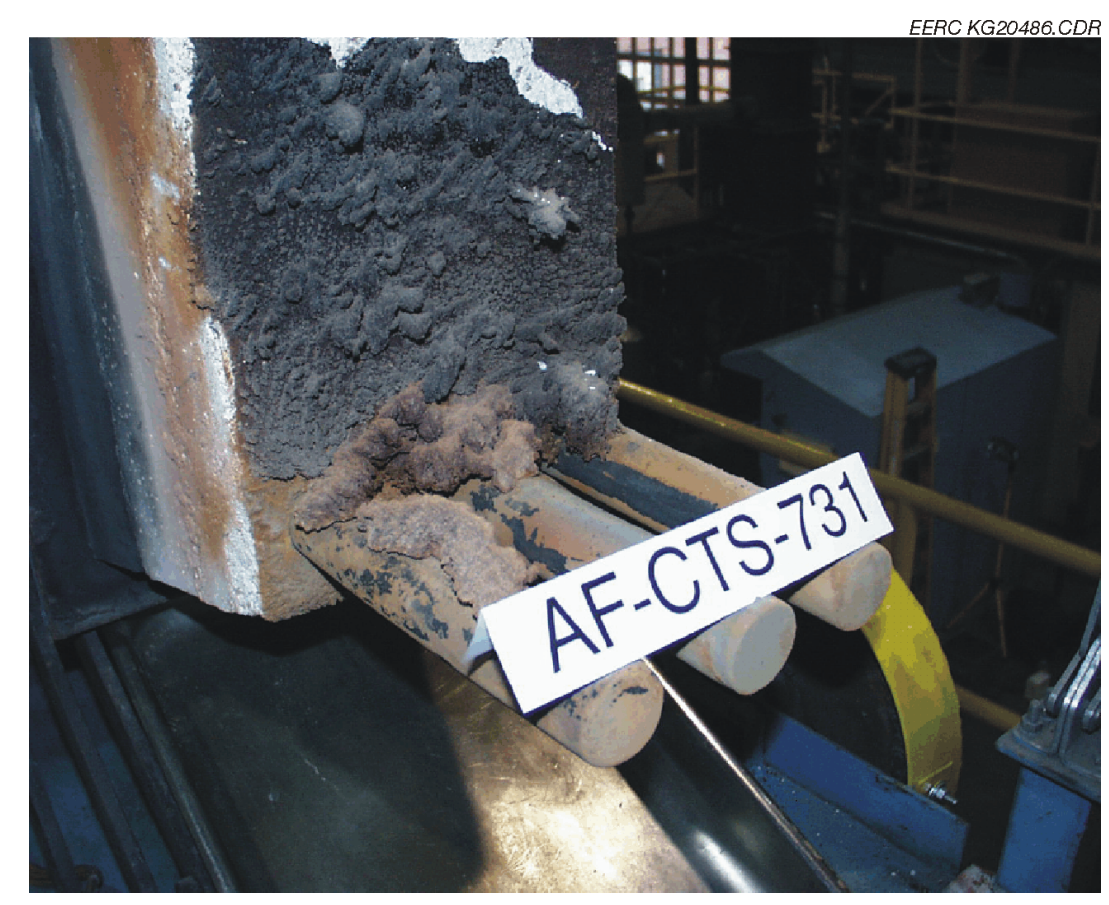

Figure 26. Photograph of the deposit produced by burning a Pittsburgh No. 8 coal at a FEGT of $2350^{\circ} \mathrm{F}\left(1290^{\circ} \mathrm{C}\right)$.

Table 23. Colbert Coal-Lignin-Biosolid Deposit Major and Minor Element Compositions, wt\%

\begin{tabular}{lccccccc}
\hline & \multicolumn{7}{c}{ Colbert Coal-Lignin-Biosolid Blend Ratio } \\
\cline { 2 - 8 } Elemental Oxide & $100: 0: 0^{\mathrm{a}}$ & $100: 0: 0^{\mathrm{b}}$ & $95: 5: 0^{\mathrm{a}}$ & $90: 10: 0^{\mathrm{a}}$ & $90: 10: 0^{\mathrm{b}}$ & $90: 5: 5^{\mathrm{a}}$ & $90: 0: 10^{\mathrm{a}}$ \\
\hline $\mathrm{SiO}_{2}$ & 55.0 & 54.1 & 53.9 & 50.7 & 53.4 & 49.6 & 45.4 \\
$\mathrm{Al}_{2} \mathrm{O}_{3}$ & 20.3 & 20.2 & 19.6 & 19.1 & 18.6 & 21.8 & 18.9 \\
$\mathrm{Fe}_{2} \mathrm{O}_{3}$ & 5.84 & 6.08 & 5.62 & 5.02 & 8.01 & 6.10 & 6.27 \\
$\mathrm{TiO}_{2}$ & 0.98 & 0.94 & 1.13 & 1.24 & 1.20 & 1.33 & 1.20 \\
$\mathrm{P}_{2} \mathrm{O}_{5}$ & 0.42 & 0.47 & 0.42 & 0.40 & 0.34 & 2.68 & 9.16 \\
$\mathrm{CaO}$ & 10.6 & 10.4 & 11.5 & 11.7 & 11.3 & 10.8 & 11.0 \\
$\mathrm{MgO}$ & 2.37 & 2.00 & 1.91 & 1.79 & 2.19 & 2.14 & 2.92 \\
$\mathrm{Na}_{2} \mathrm{O}$ & 1.82 & 1.78 & 1.83 & 1.65 & 1.64 & 2.44 & 1.40 \\
$\mathrm{~K}_{2} \mathrm{O}$ & 1.22 & 0.98 & 1.02 & 0.97 & 1.06 & 1.28 & 0.84 \\
$\mathrm{SO}_{3}$ & 0.12 & $<0.10$ & 1.00 & 0.24 & $<0.10$ & 0.87 & $<0.10$ \\
Total & 98.7 & 97 & 97.9 & 92.8 & 97.7 & 99.1 & 97.1 \\
\hline
\end{tabular}

${ }^{\mathrm{a}}$ Produced at an FEGT of $2200^{\circ} \mathrm{F}\left(1200^{\circ} \mathrm{C}\right)$.

${ }^{\mathrm{b}}$ Produced at an FEGT of $2350^{\circ} \mathrm{F}\left(1290^{\circ} \mathrm{C}\right)$. 
blend significantly increased $\mathrm{CaO}, \mathrm{TiO}_{2}$, and $\mathrm{SO}_{3}$ and decreased $\mathrm{SiO}_{2}$ contents of the resulting deposits. Biosolid cofiring increased deposited $\mathrm{P}_{2} \mathrm{O}_{5}$ concentrations.

Relative to the bulk deposit compositions in Table 23, the probe surface white ash compositions in Table 24 are greater in $\mathrm{Fe}_{2} \mathrm{O}_{3}, \mathrm{P}_{2} \mathrm{O}_{5}, \mathrm{Na}_{2} \mathrm{O}, \mathrm{K}_{2} \mathrm{O}$, and $\mathrm{SO}_{3}$. The apparent enrichment in $\mathrm{Fe}_{2} \mathrm{O}_{3}$ is probably an artifact resulting from stainless steel corrosion and contamination. The other elements, however, are generally volatilized during combustion and subsequently condense onto cooler metal surfaces. They compose the foundation for additional ash deposition.

The glass and crystalline phase assemblages for the deposits produced from burning baseline Colbert coal and Colbert coal-lignin-biosolid fuels are compared in Table 25. The deposit phase assemblages are consistent except for the deposits produced during the combustion of a 90:10 Colbert coal-lignin blend at a higher FEGT of $2350^{\circ} \mathrm{F}\left(1290^{\circ} \mathrm{C}\right)$ and a 90:10 Colbert coal-biosolid blend. The blending of $10 \mathrm{wt} \%$ lignin with Colbert coal and subsequent combustion at conditions corresponding to an FEGT of $2350^{\circ} \mathrm{F}\left(1290^{\circ} \mathrm{C}\right)$ promoted the crystallization of cristobalite, anhydrite, spinel, and merwinite at the expense of mullite and diopside. The combustion of a 90:10 Colbert coal-biosolid blend promoted the crystallization of hematite and merwinite at the expense of mullite and diopside.

Table 24. Probe Surface White Ash Major and Minor Element Compositions for Colbert Coal-Lignin-Biosolid Deposits, wt\%

\begin{tabular}{lccccccc}
\hline & \multicolumn{7}{c}{ Colbert Coal-Lignin-Biosolid Blend Ratio } \\
\cline { 2 - 7 } Elemental Oxide & $100: 0: 0^{\mathrm{a}}$ & $100: 0: 0^{\mathrm{b}}$ & $95: 5: 0^{\mathrm{a}}$ & $90: 10: 0^{\mathrm{a}}$ & $90: 10: 0^{\mathrm{b}}$ & $90: 5: 5^{\mathrm{a}}$ & $90: 0: 10^{\mathrm{a}}$ \\
\hline $\mathrm{SiO}_{2}$ & 51.2 & 47.6 & 47.5 & 47.5 & $\mathrm{NA}^{\mathrm{c}}$ & 46.9 & 41.9 \\
$\mathrm{Al}_{2} \mathrm{O}_{3}$ & 21.4 & 18.7 & 20.8 & 20.6 & $\mathrm{NA}$ & 20.1 & 19.0 \\
$\mathrm{Fe}_{2} \mathrm{O}_{3}$ & 6.36 & 10.5 & 6.44 & 5.97 & $\mathrm{NA}$ & 6.3 & 6.85 \\
$\mathrm{TiO}_{2}$ & 0.98 & 0.87 & 1.29 & 1.50 & $\mathrm{NA}$ & 1.22 & 1.02 \\
$\mathrm{P}_{2} \mathrm{O}_{5}$ & 0.75 & 0.63 & 0.88 & 0.89 & $\mathrm{NA}$ & 3.24 & 6.18 \\
$\mathrm{CaO}$ & 8.44 & 10.9 & 10.5 & 11.4 & $\mathrm{NA}$ & 10.1 & 9.33 \\
$\mathrm{MgO}$ & 2.14 & 2.02 & 1.84 & 1.78 & $\mathrm{NA}$ & 2.05 & 2.26 \\
$\mathrm{Na}_{2} \mathrm{O}$ & 3.02 & 2.27 & 2.79 & 2.59 & $\mathrm{NA}$ & 2.57 & 2.83 \\
$\mathrm{~K}_{2} \mathrm{O}$ & 1.80 & 2.13 & 1.41 & 1.36 & $\mathrm{NA}$ & 1.48 & 1.46 \\
$\mathrm{SO}_{3}$ & 3.77 & 4.63 & 5.56 & 5.53 & NA & 6.13 & 5.38 \\
$\mathrm{Total}$ & 99.9 & 100.2 & 99.0 & 99.1 & & 100.0 & 96.2 \\
\hline
\end{tabular}

${ }^{\text {a }}$ Produced at an FEGT of $2200^{\circ} \mathrm{F}\left(1200^{\circ} \mathrm{C}\right)$.

${ }^{\mathrm{b}}$ Produced at an FEGT of $2350^{\circ} \mathrm{F}\left(1290^{\circ} \mathrm{C}\right)$.

${ }^{\mathrm{c}}$ Not analyzed. 
Table 25. Colbert Coal-Lignin-Biosolid Deposit Phase Assemblage, wt\%

\begin{tabular}{|c|c|c|c|c|c|c|c|}
\hline \multirow[b]{2}{*}{ Phase, Formula } & \multicolumn{7}{|c|}{ Colbert Coal-Lignin-Biosolid Blend Ratio } \\
\hline & $100: 0: 0^{\mathrm{a}}$ & $100: 0: 0^{\mathrm{b}}$ & $95: 5: 0^{\mathrm{a}}$ & $90: 10: 0^{\mathrm{a}}$ & $90: 10: 0^{b}$ & $90: 5: 5^{\mathrm{a}}$ & $90: 0: 10^{\mathrm{a}}$ \\
\hline Glass & $\mathrm{X}^{\mathrm{c}}$ & $\mathrm{X}$ & $\mathrm{X}$ & $\mathrm{X}$ & $\mathrm{X}$ & $\mathrm{X}$ & $\mathrm{X}$ \\
\hline Quartz, $\alpha-\mathrm{SiO}_{2}$ & $\mathrm{X}$ & $\mathrm{X}$ & $\mathrm{X}$ & $\mathrm{X}$ & $\mathrm{X}$ & $\mathrm{X}$ & $\mathrm{X}$ \\
\hline Cristobalite, $\beta-\mathrm{SiO}_{4}$ & & & & & $\mathrm{X}$ & & $\mathrm{X}$ \\
\hline Hematite, $\alpha-\mathrm{Fe}_{2} \mathrm{O}_{3}$ & & & & & & & $\mathrm{X}$ \\
\hline Maghemite, $\gamma-\mathrm{Fe}_{2} \mathrm{O}_{3}$ & $X$ & $X$ & $\mathrm{X}$ & $X$ & $\mathrm{X}$ & $\mathrm{X}$ & $X$ \\
\hline Anhydrite, $\mathrm{CaSO}_{4}$ & & & & & $X$ & & \\
\hline Mullite, $\mathrm{Al}_{6} \mathrm{Si}_{2} \mathrm{O}_{13}$ & $X$ & $\mathrm{X}$ & $\mathrm{X}$ & $X$ & & $\mathrm{X}$ & \\
\hline Spinel, $\mathrm{MgAl}_{2} \mathrm{O}_{4}$ & & & & & $X$ & & \\
\hline $\begin{array}{l}\text { Plagioclase, } \\
(\mathrm{Na}, \mathrm{Ca})(\mathrm{Al}, \mathrm{Si})_{4} \mathrm{O}_{8}\end{array}$ & $X$ & $X$ & $X$ & $X$ & $X$ & $X$ & $X$ \\
\hline $\begin{array}{l}\text { Diopside, } \\
\mathrm{Ca}(\mathrm{Mg}, \mathrm{Al})(\mathrm{Si}, \mathrm{Al})_{2} \mathrm{O}_{6}\end{array}$ & $X$ & $X$ & $X$ & $X$ & & $X$ & \\
\hline $\begin{array}{l}\text { Merwinite, } \\
\mathrm{Ca}_{3} \mathrm{Mg}\left(\mathrm{SiO}_{4}\right)_{2}\end{array}$ & & & & & $X$ & & $X$ \\
\hline
\end{tabular}

The compositions of deposits produced during combustion of Pittsburgh No. 8 coal and a Pittsburgh No. 8 coal-lignin blend are compared in Table 26. The effects of lignin blending on deposit composition were to decrease $\mathrm{SiO}_{2}, \mathrm{Fe}_{2} \mathrm{O}_{3}$, and $\mathrm{P}_{2} \mathrm{O}_{5}$ and increase $\mathrm{TiO}_{2}, \mathrm{CaO}$, and $\mathrm{Na}_{2} \mathrm{O}$ concentrations. The probe surface white ash compositions in Table 27 are depleted in $\mathrm{SiO}_{2}$ and $\mathrm{Al}_{2} \mathrm{O}_{3}$ and more concentrated in $\mathrm{Fe}_{2} \mathrm{O}_{3}, \mathrm{P}_{2} \mathrm{O}_{5}, \mathrm{Na}_{2} \mathrm{O}, \mathrm{K}_{2} \mathrm{O}$, and $\mathrm{SO}_{3}$ relative to the corresponding bulk deposit compositions in Table 26. These elemental enrichments in the Pittsburgh No. 8 coal and Pittsburgh No. 8 coal-lignin deposit base layers are very similar to those for the Colbert coal-lignin-biosolid deposits. The glass and crystalline phase assemblages for the deposits produced from burning baseline Pittsburgh No. 8 coal and a Pittsburgh No. 8 coal-lignin blend are compared in Table 28. The blending of lignin with Pittsburgh No. 8 coal promoted the crystallization of maghemite at the expense of hematite.

\subsubsection{Flue Gas Compositions}

Compositions of the Colbert coal-lignin-biosolid combustion flue gases are presented in Table 29. The blending of lignin and/or biosolids with the Colbert coal generally resulted in increased $\mathrm{SO}_{2}$ and decreased $\mathrm{NO}_{x}$ production. The increase in $\mathrm{SO}_{2}$ associated with lignin blending is anticipated to be less with a commercially processed lignin, as was discussed in Section 4.2.1. Testing of the Colbert coal and Colbert coal-lignin blend at the higher FEGT of $2350^{\circ} \mathrm{F}\left(1290^{\circ} \mathrm{C}\right)$ increased $\mathrm{SO}_{2}$ production. $\mathrm{CO}_{2}$ concentrations did not vary significantly as a result of lignin and/or biosolids blending. 
Table 26. Pittsburgh No. 8 Coal-Lignin Deposit Major and Minor Element Compositions, wt\%

\begin{tabular}{lcc}
\hline & \multicolumn{1}{c}{ Pittsburgh No. 8 Coal-Lignin Blend Ratio } \\
\cline { 2 - 3 } Elemental Oxide & $100: 0$ & $90: 10$ \\
\hline $\mathrm{SiO}_{2}$ & 55.1 & 50.1 \\
$\mathrm{Al}_{2} \mathrm{O}_{3}$ & 26.3 & 27.1 \\
$\mathrm{Fe}_{2} \mathrm{O}_{3}$ & 13.9 & 9.25 \\
$\mathrm{TiO}_{2}$ & 1.1 & 1.95 \\
$\mathrm{P}_{2} \mathrm{O}_{5}$ & 0.42 & 0.15 \\
$\mathrm{CaO}$ & 3.16 & 7.82 \\
$\mathrm{MgO}$ & 0.94 & 1.14 \\
$\mathrm{Na}_{2} \mathrm{O}$ & 0.53 & 0.86 \\
$\mathrm{~K}_{2} \mathrm{O}$ & 1.84 & 1.91 \\
$\mathrm{SO}_{3}$ & $<0.10$ & $<0.10$ \\
$\mathrm{Total}$ & 103.3 & 100.3 \\
\hline
\end{tabular}

Table 27. Probe Surface White Ash Major and Minor Element Compositions for Pittsburgh No. 8 Coal-Lignin Deposits, wt\%

Pittsburgh No. 8 Coal-Lignin Blend Ratio

\begin{tabular}{lcc} 
Elemental Oxide & $100: 0$ & $90: 10$ \\
\hline $\mathrm{SiO}_{2}$ & 48.6 & 40.8 \\
$\mathrm{Al}_{2} \mathrm{O}_{3}$ & 23.7 & 22.5 \\
$\mathrm{Fe}_{2} \mathrm{O}_{3}$ & 18.2 & 12.1 \\
$\mathrm{TiO}_{2}$ & 1.11 & 1.62 \\
$\mathrm{P}_{2} \mathrm{O}_{5}$ & 1.00 & 0.39 \\
$\mathrm{CaO}$ & 3.37 & 9.06 \\
$\mathrm{MgO}$ & 1.03 & 1.20 \\
$\mathrm{Na}_{2} \mathrm{O}$ & 1.14 & 1.38 \\
$\mathrm{~K}_{2} \mathrm{O}$ & 2.25 & 2.49 \\
$\mathrm{SO}_{3}$ & 2.88 & 9.31 \\
$\mathrm{Total}$ & 103.3 & 100.8 \\
\hline
\end{tabular}


Table 28. Pittsburgh No. 8 Coal-Lignin Deposit Phase Assemblage, wt\%

\begin{tabular}{lcc}
\hline & \multicolumn{2}{c}{ Pittsburgh No. 8 Coal-Lignin Blend Ratio } \\
\cline { 2 - 3 } Phase, Formula & $100: 0$ & $90: 10$ \\
\hline Glass & $\mathrm{X}^{\mathrm{a}}$ & $\mathrm{X}$ \\
Quartz, $\alpha-\mathrm{SiO}_{2}$ & $\mathrm{X}$ & $\mathrm{X}$ \\
Hematite, $\alpha-\mathrm{Fe}_{2} \mathrm{O}_{3}$ & $\mathrm{X}$ & \\
Maghemite, $\gamma-\mathrm{Fe}_{2} \mathrm{O}_{3}$ & & $\mathrm{X}$ \\
Mullite, $\mathrm{Al}_{6} \mathrm{Si}_{2} \mathrm{O}_{13}$ & $\mathrm{X}$ & $\mathrm{X}$ \\
Plagioclase, $(\mathrm{Na}, \mathrm{Ca})(\mathrm{Al}, \mathrm{Si})_{4} \mathrm{O}_{8}$ & $\mathrm{X}$ & $\mathrm{X}$ \\
\hline${ }^{a}$ An "X" denotes that the corresponding phase is present. &
\end{tabular}

Table 29. Flue Gas Analysis Results for Colbert Coal-Lignin-Biosolid Tests

\begin{tabular}{lccccccc}
\hline & \multicolumn{7}{c}{ Colbert Coal-Lignin-Biosolids Blend Ratio } \\
\cline { 2 - 8 } Analysis Parameter & $100: 0: 0^{\mathrm{a}}$ & $100: 0: 0^{\mathrm{b}}$ & $95: 5: 0^{\mathrm{a}}$ & $90: 10: 0^{\mathrm{a}}$ & $90: 10: 0^{\mathrm{b}}$ & $90: 5: 5^{\mathrm{a}}$ & $90: 0: 10^{\mathrm{a}}$ \\
\hline $\mathrm{O}_{2}$, vol\% & 3.39 & 3.09 & 3.56 & 3.35 & 2.77 & 3.57 & 3.66 \\
$\mathrm{CO}_{2}$, vol\% & 15.2 & 15.5 & 14.1 & 15.2 & 15.4 & 13.9 & 14.9 \\
$\mathrm{SO}_{2}$, ppmv & 343 & 856 & 485 & 623 & 782 & 551 & 501 \\
$\mathrm{NO}_{\mathbf{x}}$, ppmv & 800 & 497 & 396 & 373 & 338 & 437 & 482 \\
$\mathrm{CO}$, ppmv & 7.92 & 6.47 & 4.82 & 7.65 & 36.8 & 2.63 & 13.5 \\
Excess air, vol.\% & 19.2 & 17 & 20 & 18.9 & 15.2 & 20 & 21 \\
\hline
\end{tabular}

Tested at a FEGT of $2200^{\circ} \mathrm{F}\left(1200^{\circ} \mathrm{C}\right)$.

${ }^{\mathrm{b}}$ Tested at a FEGT of $2350^{\circ} \mathrm{F}\left(1290^{\circ} \mathrm{C}\right)$.

As indicated in Table 30, the combustion of a 90:10 Pittsburgh No. 8 coal-lignin blend did not reduce $\mathrm{NO}_{\mathrm{x}}$ at the higher FEGT of $2350^{\circ} \mathrm{F}\left(1290^{\circ} \mathrm{C}\right)$. $\mathrm{SO}_{2}$ concentration was reduced greatly as a result of lignin cofiring with the Pittsburgh No. 8 coal because of ash sulfation as discussed in Section 4.5.7. $\mathrm{CO}_{2}$ concentrations were similar in the baseline Pittsburgh No. 8 coal and the Pittsburgh No. 8 coal-lignin combustion flue gas.

\subsubsection{Fly Ash Particle-Size Distributions}

The particle-size distributions of fly ashes sampled from the ESP inlet were determined using a 5-stage multicyclone. The particle-size distributions for fly ashes produced from burning the Colbert coal and Colbert coal-lignin-biosolid blends are compared in Figure 27. These results indicate that lignin blending did not significantly affect the particle-size distribution of Colbert coal fly ash. The higher FEGT of $2350^{\circ} \mathrm{F}\left(1290^{\circ} \mathrm{C}\right)$ greatly increased the fly ash particle size of Colbert fly ash, but not the Colbert coal-lignin (90:10) blend. The blending of biosolids alone produced a much finer ash, probably because most of the inorganic ash components of the biosolids are very 
Table 30. Flue Gas Analysis Results for Pittsburgh No. 8 Coal-Lignin Tests

\begin{tabular}{lcc}
\hline & \multicolumn{2}{c}{ Pittsburgh No. 8 Coal-Lignin Blend Ratio } \\
\cline { 2 - 3 } Analysis Parameter & $100: 0$ & $90: 10$ \\
\hline $\mathrm{O}_{2}$, vol\% & 3.4 & 3.38 \\
$\mathrm{CO}_{2}$, vol\% & 15.2 & 15.4 \\
$\mathrm{SO}_{2}$, ppmv & 971 & 382 \\
$\mathrm{NO}_{x}$, ppmv & 414 & 445 \\
$\mathrm{CO}$, ppmv & 6.25 & 3.94 \\
Excess Air, vol\% & 19 & 18.9 \\
\hline
\end{tabular}

small and organically bound (Figure 4). The Colbert coal-lignin-biosolid (90:5:5) blend, however, produced the coarsest ash of all the fuels. Apparently, the lignin-biosolid combination promotes the formation of larger coal fly ash particles which should be more easily captured by conventional pollution control equipment (e.g., baghouse or ESP). As indicated in Figure 28, the particle-size distributions of fly ashes produced from burning the Pittsburgh No. 8 coal and a Pittsburgh No. 8 coal-lignin (90:10) blend are very similar.

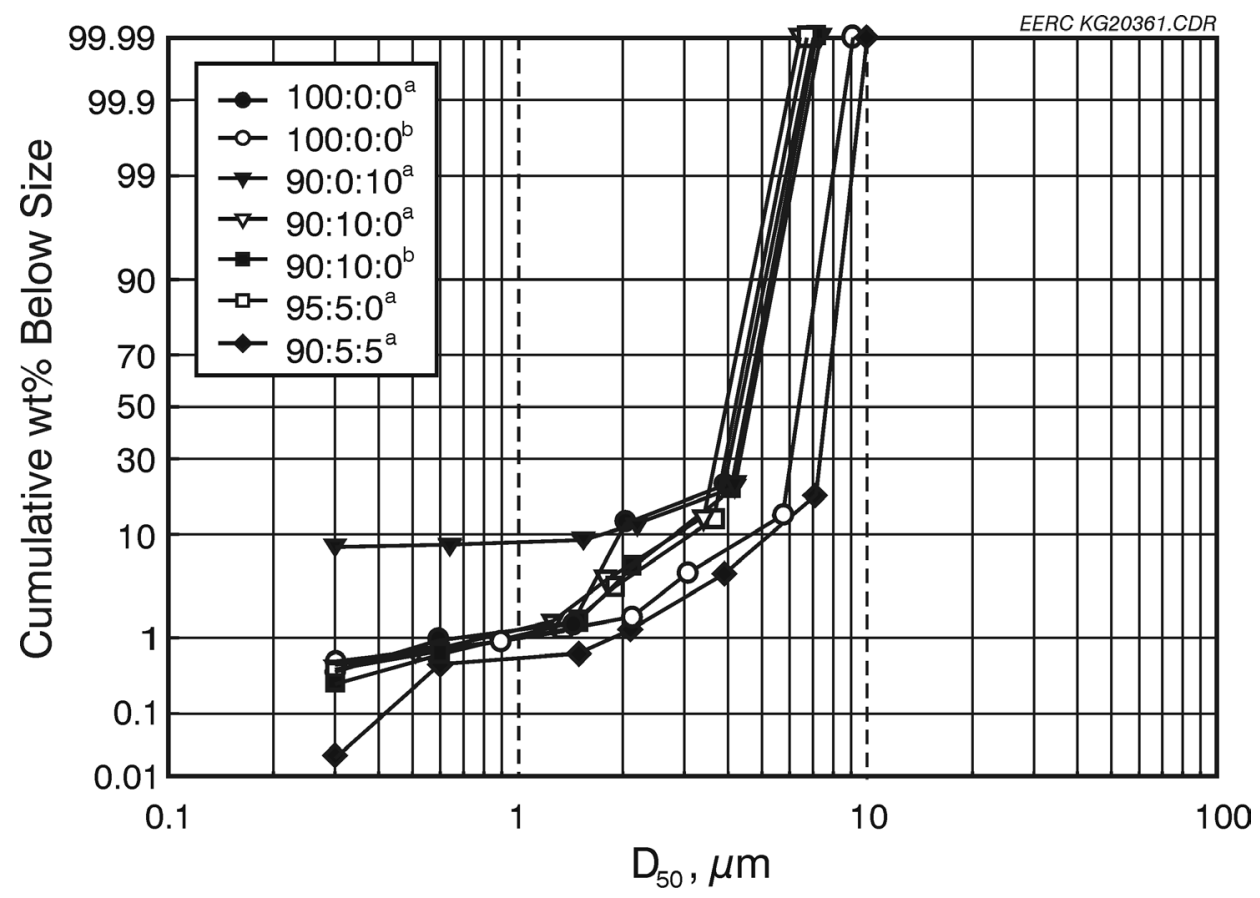

Figure 27. Comparison of Colbert coal and Colbert coal-lignin-biosolid fly ash particle-size distributions: a) fuel tested at an FEGT of $2200^{\circ} \mathrm{F}\left(1200^{\circ} \mathrm{C}\right)$ and

b) fuel tested at an FEGT of $2350^{\circ} \mathrm{F}\left(1290^{\circ} \mathrm{C}\right)$. 


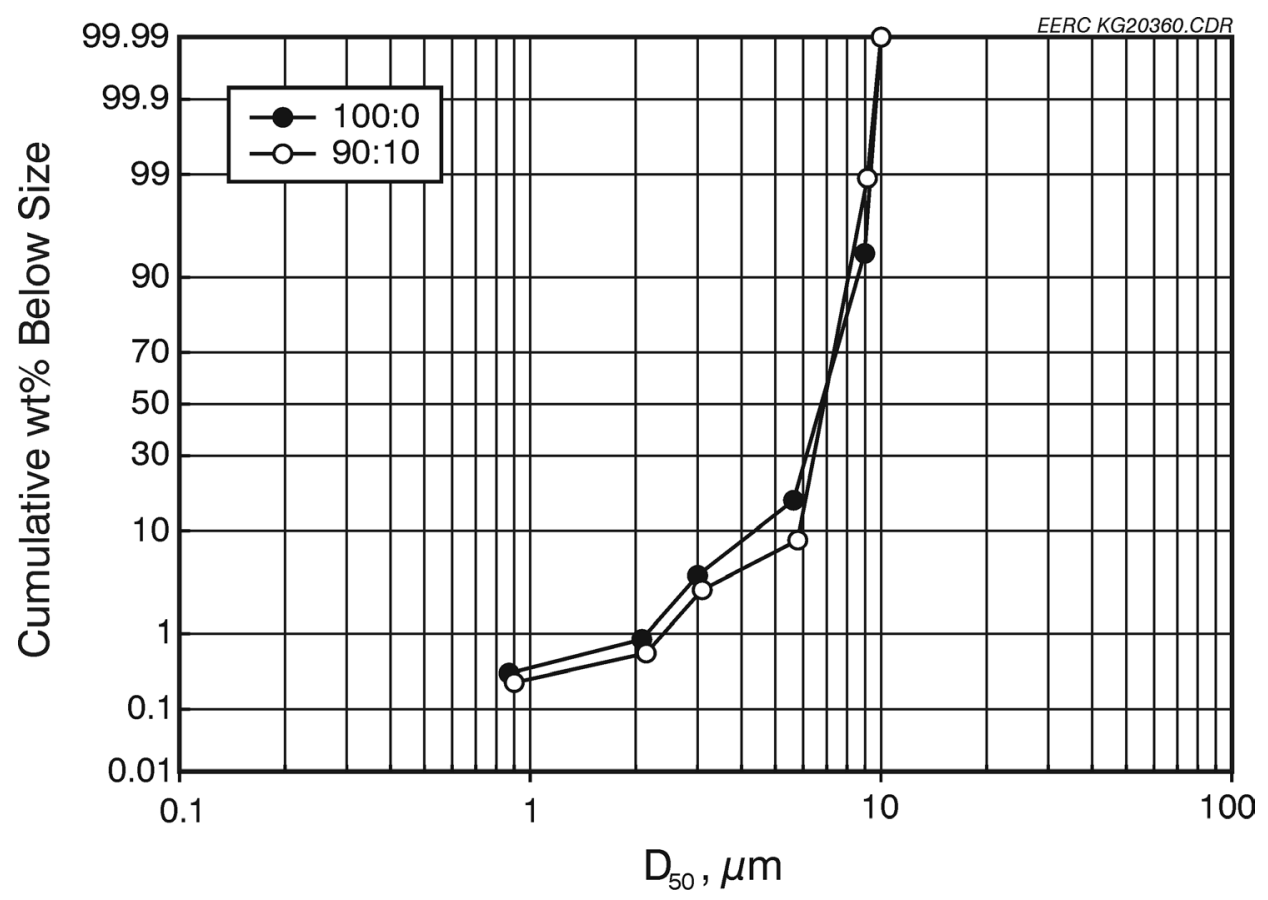

Figure 28. Comparison of Pittsburgh No. 8 coal and Pittsburgh No. 8 coal-lignin fly ash particlesize distributions.

\subsubsection{Fly Ash Chemical and Mineralogical Compositions}

The chemical compositions of Colbert coal and Colbert coal-lignin-biosolid blend fly ashes are compared in Table 31 . The cofiring of lignin with the Colbert coal blend significantly increased $\mathrm{CaO}, \mathrm{TiO}_{2}$, and $\mathrm{SO}_{3}$ and decreased $\mathrm{Na}_{2} \mathrm{O}$ and $\mathrm{C}$ contents of the resulting fly ashes. Biosolid cofiring increased fly ash $\mathrm{P}_{2} \mathrm{O}_{5}$ content. Lignin and biosolid cofiring improved combustion reactivity as evidenced by the lower carbon concentrations in the fuel blend fly ashes relative to the baseline $(100 \mathrm{wt} \%)$ Colbert coal fly ashes.

The amorphous (i.e., glass) and crystalline phases identified in the parent Colbert coal and fuel blend fly ashes are presented in Table 32. Glass, quartz, lime, maghemite, and mullite are ubiquitous phases in the parent Colbert coal fly ashes and in the fly ashes produced by burning Colbert coal-lignin blends. In addition, plagioclase is present in the baseline Colbert coal fly ash produced at a FEGT of $2200^{\circ} \mathrm{F}\left(1200^{\circ} \mathrm{C}\right)$ and in the $90: 10$ Colbert coal-lignin blend fly ash. The blending of $10 \mathrm{wt} \%$ acidified biosolids to the Colbert coal inhibited $\mathrm{CaO}$ crystallization and promoted the formation of hematite at the expense of maghemite.

Pittsburgh No. 8 coal and coal-lignin (90:10) blend fly ash compositions are compared in Table 33. The blending of lignin with the Pittsburgh No. 8 coal resulted in the production of a fly ash containing less $\mathrm{SiO}_{2}, \mathrm{Fe}_{2} \mathrm{O}_{3}$, and $\mathrm{P}_{2} \mathrm{O}_{5}$ but significantly more $\mathrm{TiO}_{2}, \mathrm{CaO}, \mathrm{MgO}, \mathrm{Na}_{2} \mathrm{O}$, and $\mathrm{SO}_{3}$. The baseline Pittsburgh No. 8 coal fly ash is composed largely of glass and three crystalline phases; 
Table 31. Colbert Coal-Lignin-Biosolid Fly Ash Major and Minor Element Compositions, wt\%

\begin{tabular}{lccccccc}
\hline Elemental & \multicolumn{7}{c}{ Colbert Coal-Lignin-Biosolid Blend Ratio } \\
\cline { 2 - 8 } Oxide & $100: 0: 0^{\mathrm{a}}$ & $100: 0: 0^{\mathrm{b}}$ & $95: 5: 0^{\mathrm{a}}$ & $90: 10: 0^{\mathrm{a}}$ & $90: 10: 0^{\mathrm{b}}$ & $95: 5: 5^{\mathrm{a}}$ & $90: 0: 10^{\mathrm{a}}$ \\
\hline $\mathrm{SiO}_{2}$ & 51.8 & 47.4 & 51.2 & 47.8 & 48.6 & 49.6 & 47.9 \\
$\mathrm{Al}_{2} \mathrm{O}_{3}$ & 22.7 & 21.5 & 22.0 & 21.3 & 20.7 & 21.8 & 20.2 \\
$\mathrm{Fe}_{2} \mathrm{O}_{3}$ & 5.86 & 6.33 & 5.84 & 5.39 & 6.46 & 6.10 & 5.91 \\
$\mathrm{TiO}_{2}$ & 1.04 & 0.97 & 1.31 & 1.52 & 1.48 & 1.33 & 1.09 \\
$\mathrm{P}_{2} \mathrm{O}_{5}$ & 0.61 & 0.73 & 0.64 & 0.61 & 0.44 & 2.68 & 5.49 \\
$\mathrm{CaO}$ & 9.75 & 9.18 & 10.6 & 11.2 & 11.2 & 10.8 & 9.23 \\
$\mathrm{MgO}$ & 2.44 & 2.00 & 1.96 & 1.90 & 2.19 & 2.14 & 2.28 \\
$\mathrm{Na}_{2} \mathrm{O}$ & 2.74 & 2.65 & 2.46 & 2.15 & 2.25 & 2.44 & 2.55 \\
$\mathrm{~K}_{2} \mathrm{O}$ & 1.48 & 1.22 & 1.21 & 1.15 & 1.26 & 1.28 & 1.16 \\
$\mathrm{SO}_{3}$ & 0.46 & 0.49 & 0.83 & 1.07 & 1.41 & 0.84 & 0.41 \\
$\mathrm{C}$ & 2.42 & 4.48 & 1.51 & 1.04 & 0.70 & 0.71 & 0.82 \\
Total & 101.3 & 97.0 & 99.6 & 95.1 & 96.7 & 99.8 & 97.0 \\
\hline
\end{tabular}

${ }^{\mathrm{a}}$ Produced at an FEGT of $2200^{\circ} \mathrm{F}\left(1200^{\circ} \mathrm{C}\right)$.

${ }^{\mathrm{b}}$ Produced at an FEGT of $2350^{\circ} \mathrm{F}\left(1290^{\circ} \mathrm{C}\right)$.

Table 32. Colbert Coal-Lignin-Biosolid Fly Ash Phase Assemblages, wt\%

\begin{tabular}{lccccccc}
\hline & \multicolumn{7}{c}{ Colbert Coal-Lignin-Biosolid Blend Ratio } \\
\cline { 2 - 7 } Phase, Formula & $100: 0: 0^{\mathrm{a}}$ & $100: 0: 0^{\mathrm{b}}$ & $95: 5: 0^{\mathrm{a}}$ & $90: 10: 0^{\mathrm{a}}$ & $90: 10: 0^{\mathrm{b}}$ & $95: 5: 5^{\mathrm{a}}$ & $90: 0: 10^{\mathrm{a}}$ \\
\hline Glass & $\mathrm{X}^{\mathrm{c}}$ & $\mathrm{X}$ & $\mathrm{X}$ & $\mathrm{X}$ & $\mathrm{X}$ & $\mathrm{X}$ & $\mathrm{X}$ \\
Quartz, $\mathrm{SiO}_{2}$ & $\mathrm{X}$ & $\mathrm{X}$ & $\mathrm{X}$ & $\mathrm{X}$ & $\mathrm{X}$ & $\mathrm{X}$ & $\mathrm{X}$ \\
$\mathrm{Lime}, \mathrm{CaO}$ & $\mathrm{X}$ & $\mathrm{X}$ & $\mathrm{X}$ & $\mathrm{X}$ & $\mathrm{X}$ & $\mathrm{X}$ & \\
Hematite, $\alpha-\mathrm{Fe}_{2} \mathrm{O}_{3}$ & & $\mathrm{X}$ & $\mathrm{X}$ & $\mathrm{X}$ & $\mathrm{X}$ & $\mathrm{X}$ & $\mathrm{X}$ \\
Maghemite, $\gamma-\mathrm{Fe}_{2} \mathrm{O}_{3}$ & $\mathrm{X}$ & $\mathrm{X}$ & $\mathrm{X}$ & $\mathrm{X}$ & $\mathrm{X}$ & $\mathrm{X}$ & $\mathrm{X}$ \\
Mullite, $\mathrm{Al}_{6} \mathrm{Si}_{2} \mathrm{O}_{13}$ & $\mathrm{X}$ & $\mathrm{X}$ & & & & & \\
Plagioclase, & & & & & & & \\
$\quad \mathrm{Na}, \mathrm{Ca})(\mathrm{Al}, \mathrm{Si})_{4} \mathrm{O}_{8}$ & $\mathrm{X}$ & & & & & &
\end{tabular}

${ }^{a}$ Produced at an FEGT of $2200^{\circ} \mathrm{F}\left(1200^{\circ} \mathrm{C}\right)$.

${ }^{\mathrm{b}}$ Produced at an FEGT of $2350^{\circ} \mathrm{F}\left(1290^{\circ} \mathrm{C}\right)$.

"An " $\mathrm{X}$ " denotes that the corresponding phase is present. 
Table 33. Pittsburgh No. 8 Coal-Lignin Fly Ash Major and Minor Element Compositions, wt\%

\begin{tabular}{lcc}
\hline \multirow{2}{*}{$\begin{array}{l}\text { Elemental } \\
\text { Oxide }\end{array}$} & \multicolumn{2}{c}{ Pittsburgh No. 8 Coal-Lignin Blend Ratio } \\
\cline { 2 - 3 } $\mathrm{SiO}_{2}$ & 51.7 & $90: 10$ \\
$\mathrm{Al}_{2} \mathrm{O}_{3}$ & 24.4 & 46.9 \\
$\mathrm{Fe}_{2} \mathrm{O}_{3}$ & 14.2 & 25.5 \\
$\mathrm{TiO}_{2}$ & 1.14 & 9.08 \\
$\mathrm{P}_{2} \mathrm{O}_{5}$ & 0.70 & 1.71 \\
$\mathrm{CaO}$ & 3.22 & 0.25 \\
$\mathrm{MgO}$ & 0.91 & 9.02 \\
$\mathrm{Na}_{2} \mathrm{O}$ & 0.77 & 1.30 \\
$\mathrm{~K}_{2} \mathrm{O}$ & 2.00 & 1.01 \\
$\mathrm{SO}_{3}$ & 0.76 & 1.91 \\
$\mathrm{Total}$ & 99.8 & 3.33 \\
\hline
\end{tabular}

quartz, hematite, and mullite (Table 34). The blending of lignin with the Pittsburgh No. 8 coal promoted the crystallization of lime and anhydrite as well as maghemite at the expense of hematite. The sulfation of lime to produce anhydrite greatly reduced the $\mathrm{SO}_{2}$ concentration of the flue gas as indicated in Table 30.

Table 34. Pittsburgh No. 8 Coal-Lignin Fly Ash Phase Assemblages, wt\%

\begin{tabular}{lcc}
\hline & \multicolumn{2}{c}{ Pittsburgh No. 8 Coal-Lignin Blend Ratio } \\
\cline { 2 - 3 } Phase, Formula & $100: 0$ & $90: 10$ \\
\hline Glass & $\mathrm{X}^{\mathrm{a}}$ & $\mathrm{X}$ \\
Quartz, $\mathrm{SiO}_{2}$ & $\mathrm{X}$ & $\mathrm{X}$ \\
$\mathrm{Lime}, \mathrm{CaO}$ & & $\mathrm{X}$ \\
Anhydrite, $\mathrm{CaSO}_{4}$ & & $\mathrm{X}$ \\
Hematite, $\alpha-\mathrm{Fe}_{2} \mathrm{O}_{3}$ & $\mathrm{X}$ & \\
Maghemite, $\gamma-\mathrm{Fe}_{2} \mathrm{O}_{3}$ & & $X$ \\
Mullite, $\mathrm{Al}_{6} \mathrm{Si}_{2} \mathrm{O}_{13}$ & $\mathrm{X}$ & $\mathrm{X}$ \\
\hline
\end{tabular}

" An " $\mathrm{X}$ " denotes that the corresponding phase is present. 


\subsection{SUMMARY}

Lignin, derived from municipal solid waste and renewable biosolid feedstocks using Masada Resource Group's patented CES OxyNol ${ }^{\mathrm{TM}}$ process, and acidified biosolids were evaluated as supplemental fuels with an $80 \mathrm{wt} \%$ Colorado- $20 \mathrm{wt} \%$ subbituminous PRB coal blend from the TVA Colbert Steam Plant and a bituminous Pittsburgh No. 8 coal. The lignin and acidified biosolids are characterized by possessing higher moisture contents and lower carbon, hydrogen, and heating values relative to the coals. Ash contents of the fuels are similar. The lignin also possesses higher concentrations of $\mathrm{TiO}_{2}, \mathrm{CaO}$, and $\mathrm{SO}_{3}$ and lower concentrations of $\mathrm{SiO}_{2}, \mathrm{Al}_{2} \mathrm{O}_{3}, \mathrm{Fe}_{2} \mathrm{O}_{3}, \mathrm{~K} 2 \mathrm{O}$, and $\mathrm{N}$ relative to the coals. The relatively high sulfur content of the lignin could be reduced through a more thorough washing and drying of the lignin in an efficient commercial-scale dewatering device. The acidified biosolids were characterized by higher concentrations of $\mathrm{P}_{2} \mathrm{O}_{5}$ and lower $\mathrm{SiO}_{2}$ and $\mathrm{Al}_{2} \mathrm{O}_{3}$ relative to the other fuels. Trace element concentrations, especially for $\mathrm{Cr}, \mathrm{Pb}, \mathrm{Hg}$, and $\mathrm{Ni}$, were generally greater in the lignin and acidified biosolids fuels relative to the Colbert coal. Maximum trace element emission factors were calculated for a 95:5 Colbert coal-lignin blend and 90:5:5 Colbert coal-lignin-acidified biosolid blends and compared to EPA emission factors for pulverized coal-fired units that are unequipped with pollution control devices (9). Calculated maximum trace element emission factors for the fuel blends were generally less than or within the range of those for the uncontrolled coal-fired units, except for $\mathrm{Cr}$ and $\mathrm{Pb}$ which were greater.

CCSEM analyses indicate that the Colbert coal contains primarily quartz, clays (kaolinite, mixed clays, and illite), and carbonate minerals (calcite and dolomite-ankerite). Pittsburgh No. 8 coal contains pyrite in addition to the same minerals contained in the Colbert coal. Lignin is composed primarily of gypsum. The acidified biosolids contain relatively high proportions of gypsum and quartz. Minerals in the Colbert coal blend are generally larger relative to the Pittsburgh No. 8 coal. The lignin mineral-size distribution is essentially intermediate relative to the two coals, whereas minerals present in the biosolids are much finer relative to the other fuels.

Thermochemical equilibrium modeling was conducted to predict the partial melting and viscosity characteristics of the coals, lignin, biosolids, and fuel blends. Model predictions suggest that the blending of lignin and/or biosolids with the Colbert coal at relatively low proportions $(\leq 10$ dry wt $\%)$ does not significantly affect ash-melting characteristics or liquid-phase viscosity. The blending of 10 dry wt $\%$ lignin with the Pittsburgh No. 8 coal, however, is predicted to increase the production of silicate liquid by $5-18 \mathrm{wt} \%$ for a given temperature and significantly reduce viscosity at $>1225^{\circ} \mathrm{C}\left(>2240^{\circ} \mathrm{F}\right)$. The production of a low-viscosity silicate liquid should promote ash deposition.

Nine combustion tests, described in Table 1, were conducted in a pilot-scale $(550,000-\mathrm{Btu} / \mathrm{hr}$ $[580-\mathrm{MJ} / \mathrm{hr}])$ combustion system to evaluate the effects of coal characteristics, blend mixture, and FEGT on boiler heat exchange surface slagging and fouling; $\mathrm{NO}_{x}, \mathrm{CO}_{2}$, and $\mathrm{SO}_{\mathrm{x}}$ production; fly ash characteristics; and combustion efficiency. During the fuel preparation processes (e.g., blending and pulverization), it was found that lignin and biosolids dried to $<40 \mathrm{wt} \%$ moisture did not present handling, pulverization, or fuel homogeneity problems. The blending of lignin and/or biosolids to the Colbert coal did not significantly affect bottom ash-entrained ash partitioning in the combustion system. An increase in the FEGT from $2200^{\circ} \mathrm{F}\left(1200^{\circ} \mathrm{C}\right)$ to $2350^{\circ} \mathrm{F}\left(1290^{\circ} \mathrm{C}\right)$, however, resulted in the production of about $30 \mathrm{wt} \%$ more bottom ash. Similar to the Colbert coal cofiring tests, the 
blending of lignin with the Pittsburgh No. 8 coal did not significantly affect bottom ash-entrained ash partitioning.

Ash deposition rates were lowest for the baseline (100:0:0) Colbert coal tests and highest for the 90:10 Colbert coal-lignin blend tested at the higher FEGT of $2350^{\circ} \mathrm{F}\left(1290^{\circ} \mathrm{C}\right)$. The combination of lignin blending and relatively high FEGT enhanced the rate of ash deposition by $410 \%$. Lignin cofiring at the FEGT of $2200^{\circ} \mathrm{F}\left(1200^{\circ} \mathrm{C}\right)$ and blend levels of 5 and 10 dry wt $\%$ increased the ash deposition rate by $18 \%$ and $79 \%$, respectively, relative to the baseline Colbert coal. Deposition rates for the acidified biosolid cofire tests were $34 \%$ and $128 \%$ greater than those resulting from lignin cofiring alone at the lower FEGT of $2200^{\circ} \mathrm{F}\left(1200^{\circ} \mathrm{C}\right)$. The acidified biosolids enhanced ash deposition more so than lignin. Contrary to the thermochemical equilibrium modeling predictions, the cofiring of lignin with Pittsburgh No. 8 coal had little effect on ash deposition.

Deposits produced from burning 100:0:0, 95:5:0, 90:10:0, and 90:5:5 Colbert coal-lignin-biosolid fuels at a FEGT of $2200^{\circ} \mathrm{F}\left(1200^{\circ} \mathrm{C}\right)$ were friable and, therefore, easily removed from the simulated steam tube surfaces. Deposits produced during the combustion of a 90:10 Colbert coal-lignin blend at the higher FEGT of $2350^{\circ} \mathrm{F}\left(1290^{\circ} \mathrm{C}\right)$ and $90: 10$ Colbert coal-biosolid blend were more tenacious and thus more difficult to remove. Deposits produced from the Pittsburgh No. 8 coal and 90:10 Pittsburgh No. 8 coal-lignin blend were harder than those produced from the Colbert coal and Colbert coal-lignin blends at a FEGT of $2200^{\circ} \mathrm{F}\left(1200^{\circ} \mathrm{C}\right)$.

The cofiring of lignin with the Colbert coal blend significantly increased $\mathrm{CaO}, \mathrm{TiO}_{2}$, and $\mathrm{SO}_{3}$ and decreased $\mathrm{SiO}_{2}$ contents of the resulting deposits. Biosolid cofiring increased deposited $\mathrm{P}_{2} \mathrm{O}_{5}$ concentrations. Deposits resulting from the combustion of a 90:10 Pittsburgh No. 8 coal-lignin blend were depleted in $\mathrm{SiO}_{2}, \mathrm{Fe}_{2} \mathrm{O}_{3}$, and $\mathrm{P}_{2} \mathrm{O}_{5}$ and enriched in $\mathrm{TiO}_{2}, \mathrm{CaO}$, and $\mathrm{Na}_{2} \mathrm{O}$ relative to baseline (100 wt\%) Pittsburgh No. 8 deposits. All deposits formed on a white initial deposition layer rich in $\mathrm{P}_{2} \mathrm{O}_{5}, \mathrm{Na}_{2} \mathrm{O}, \mathrm{K}_{2} \mathrm{O}$, and $\mathrm{SO}_{3}$. In general, lignin and biosolids blending did not significantly affect deposit crystalline phase compositions.

Lignin blending with the Colbert coal resulted in about a $50 \%$ reduction in $\mathrm{NO}_{\mathrm{x}} \cdot \mathrm{CO}_{2}$ concentrations did not vary significantly as a result of lignin and/or biosolids blending. In general, $\mathrm{SO}_{2}$ concentrations increased as a result of lignin blending because the lignin was not thoroughly washed. In contrast, lignin blending with the Pittsburgh No. 8 coal did not result in the reduction of $\mathrm{NO}_{\mathrm{x}}$ at the higher FEGT of $2350^{\circ} \mathrm{F}\left(1290^{\circ} \mathrm{C}\right)$, and $\mathrm{SO}_{2}$ production was decreased by about $60 \%$ as a result of ash sulfation (i.e., formation of anhydrite).

The combination of lignin and biosolid blending with the Colbert coal promoted the formation of larger fly ash particles which should be more easily captured by conventional pollution control equipment (e.g., baghouse or ESP). Lignin and biosolid cofiring improved combustion reactivity as evidenced by lower carbon concentrations in the fuel blend fly ashes relative to the baseline (100 wt \%) Colbert coal fly ashes. Additional fly ash compositional changes resulting from lignin and biosolids blending were similar to those for their respective deposits.

\subsection{CONCLUSIONS}

Combustion test results indicate that the cofiring of lignin and/or acidified biosolids with 
Colbert coal will increase the rate of ash deposition. The acidified biosolids enhanced the rate of ash deposition more so than lignin. Fortunately, the deposits produced at a FEGT of $2200^{\circ} \mathrm{F}\left(1200^{\circ} \mathrm{C}\right)$ were friable and very loosely bound to simulated superheater surfaces; therefore, they should be easily removed via sootblowing in a full-scale boiler. The cofiring of relatively low proportions $(\leq 5$ dry wt $\%)$ of lignin and/or biosolids at a FEGT of $\leq 2200^{\circ} \mathrm{F}\left(\leq 1200^{\circ} \mathrm{C}\right)$ should not create catastrophic ash deposition problems. However, the combination of relatively high lignin and/or biosolid blend proportions $(\geq 10 \mathrm{dry} \mathrm{wt} \%)$ and FEGT of $\geq 2350^{\circ} \mathrm{F}\left(\geq 1290^{\circ} \mathrm{C}\right)$ is expected to produce large tenacious deposits and thus should be avoided. Benefits of cofiring relatively small proportions of lignin with the Colbert coal are primarily threefold: 1) increases utilization of biomass energy, 2) reduces $\mathrm{NO}_{\mathrm{x}}$ emissions, and 3) improves combustion efficiency resulting in reduced fly ash carbon contents.

The cofiring of 10 dry wt $\%$ lignin with the Pittsburgh No. 8 coal did not significantly affect entrained ash/bottom ash partitioning or the ash deposition rate, even though thermodynamic calculations predicted the formation of additional low-viscosity silicate liquid. In contrast to the Colbert coal, the cofiring of lignin with Pittsburgh No. 8 coal did not reduce $\mathrm{NO}_{\mathrm{x}}$ production, but did reduce $\mathrm{SO}_{2}$ via ash sulfation (i.e., formation of anhydrite).

\subsection{REFERENCES}

1. Energy Information Administration. Annual Energy Outlook: 1999 with Projections to 2020; DOE/EIA-0383(99); Office of Integrated Analysis and Forecasting, U.S. Department of Energy: Washington, DC, Dec 1998.

2. Executive Order 13134, Aug 12, 1999.

3. Broder, J.D.; Harris, R.A.; Ranney, J.T. Using MSW and Industrial Residues as Ethanol Feedstocks. BioCycle 2001, 42 (10), 23-26.

4. Zygarlicke, C.J.; McCollor, D.P.; Pavlish. J.H. Ash Behavior and Combustion Performance During the Cofiring of Rice Straw Lignin and Coal. In Proceedings of 9th Biennial Bioenergy Conference: Moving Technology into the Marketplace; Buffalo, NY, Oct 15-19, 2000; 12 p.

5. Tennessee Valley Authority, Personal Communication, June 2001.

6. Smith, W.B.; Wilson, R.R. Jr. Development and Laboratory Evaluation of a Five-Stage Cyclone System; EPA 600/7-78-008 (NTIS PB 279084); U.S. Environmental Protection Agency: Research Triangle Park, NC, 1978; 66 p. 
7. Galbreath, K.; Zygarlicke, C.; Casuccio, G.; Moore, T.; Gottlieb, P.; Agron-Olshina, N.; Huffman, G.; Shah, A.; Yang, N.; Vleeskens, J.; Hamburg, G. Collaborative Study of Quantitative Coal Mineral Analysis Using Computer-Controlled Scanning Electron Microscopy. Fuel 1996, 75 (4), 424-430.

8. Russo, L.J., President of LIZAN Process Solutions. Personal communication, Oct 15, 2001.

9. EPA Compilation of Air Pollutant Emission Factors; Vol. I, Chapter 1: External Combustion Sources, 5th ed.; AP-42; U.S. Environmental Protection Agency Office of Air Quality Planning and Standards: Research Triangle Park, NC, Nov 1996.

10. Bale, C.W.; Pelton, A.D.; Thompson, W.T. FACT 2.1 User Manual; Ecole Polytechnique de Montreal/Royal Military College, Canada, 1996.

11. Kalmanovitch, D.P.; Frank, M. An Effective Model of Viscosity for Ash Deposition Phenomena. In Proceedings of Mineral Matter and Ash Deposition from Coal; Bryers, R.W.; Vorres, K.S., Eds.; Engineering Foundation Conference on Minerology; 1988; 89 p. 